RENATA GOMES SOUTO

\title{
GESTÃO DO PROCESSO DE PLANEJAMENTO DA PRODUÇÃO EM EMPRESAS CONSTRUTORAS DE EDIFÍCIOS: ESTUDOS DE CASO
}

Dissertação apresentada à Escola Politécnica da Universidade de São Paulo para obtenção do título de Mestre em Engenharia 
RENATA GOMES SOUTO

\section{GESTÃO DO PROCESSO DE PLANEJAMENTO DA PRODUÇÃO EM EMPRESAS CONSTRUTORAS DE EDIFÍCIOS: ESTUDOS DE CASO}

Dissertação apresentada à Escola Politécnica da Universidade de São Paulo para obtenção do título de Mestre em Engenharia

Área de concentração:

Engenharia de Construção Civil e Urbana

Orientador:

Prof. Dr. Silvio Burrattino Melhado 


\section{AGRADECIMENTOS}

Ao professor e amigo Silvio Burrattino Melhado pela orientação e apoio necessário ao desenvolvimento do trabalho. Também sua força, paciência e incentivo foram muito valiosos. Muito obrigado!

Aos professores Ubiraci Espinelli Lemas de Souza e Sérgio Alfredo Rosa da Silva pelas contribuições na apresentação do meu Exame de Qualificação.

Aos queridos colegas e amigos do CTE, que me ensinam muito sobre força de vontade e competência: Ana Cecília, Anderson, Daniel, Fabiana, Geraldo, Giancarlo, Luciana, Marcia, Maurício, Sandra, Saulo, Tamaki e Waldir. E pelos que passaram por lá e também contribuíram com a minha formação como pessoa e profissional: Alberto, Ana Rocha, Gláucia, Josaphat e Taveira. E ao Roberto de Souza, que me ofereceu a oportunidade de participar deste grupo, sempre incentivador do nosso desenvolvimento.

Pelos ensinamentos tanto profissionais como de vida: Ruy. Muito obrigado pelo incentivo, contribuições, discussões e correções!

As empresas e profissionais que participaram desta pesquisa: Eng ${ }^{o}$ Edison e Eng ${ }^{a}$ Jane

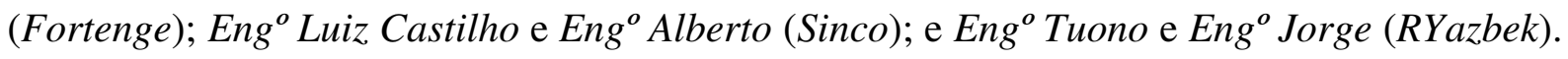
Também foi muito importante a contribuição de outras empresas consultadas: Eng ${ }^{o}$ Renê (Matec); Engo Ivo (Tecco); Eng ${ }^{o}$ Adhemar (Incorbase); Eng ${ }^{a}$ Daileine (Schahin); Sr. Gilvan (Setin). Estas empresas são a demonstração que a integração entre o mundo acadêmico e profissional não só é possível como necessário.

A todos os meus amigos de turma, em especial Ana Luisa, Auriciane, Fabiana, Manuela e Rosiany. Obrigado pela força nos inúmeros trabalhos!

Sempre atenciosa e prestativa, Fátima. Muito obrigado pelas orientações!

Por toda a paciência do mundo, Rogério.

E com muito carinho, a minha família: vó Teresa, muito obrigado pelas orações!; Roberta, que seu sorriso continue sempre iluminado e seu coração "grande e espaçoso" - não se esqueça, nós te amamos e admiramos muito!; e meus pais, Mario e Maria, que são os grandes responsáveis pelo que Sou. 
1 INTRODUÇÃ

1.1 JUSTIFICATIVA DA PESQUISA E IMPORTÂNCIA DO TEMA …....................................... 1

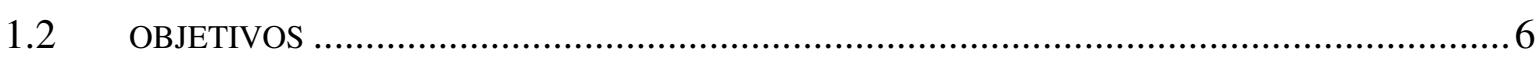

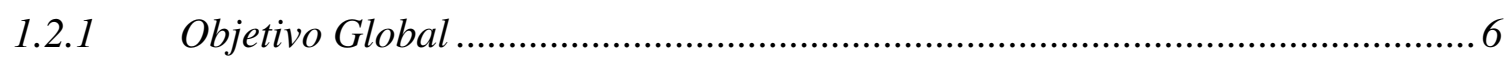

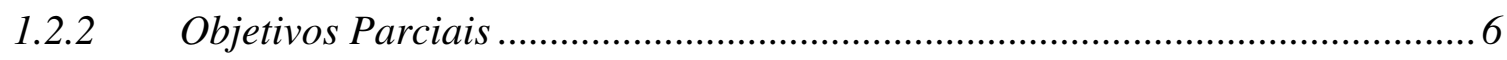

1.3 MÉTODO DE PESQUISA E REDAÇÃO DA DISSERTAÇÃO ................................................. 7

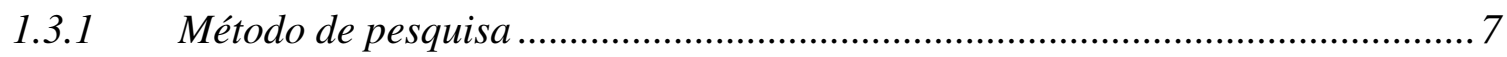

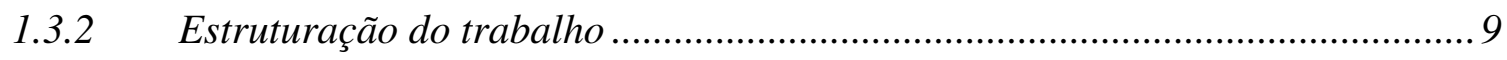

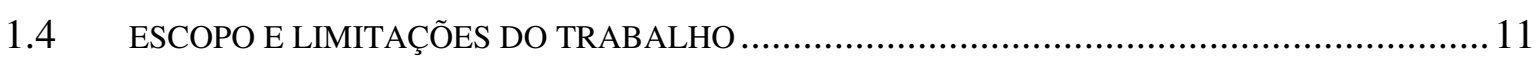

\section{GESTÃO DO PROCESSO DE PLANEJAMENTO DA PRODUÇÃO EM}

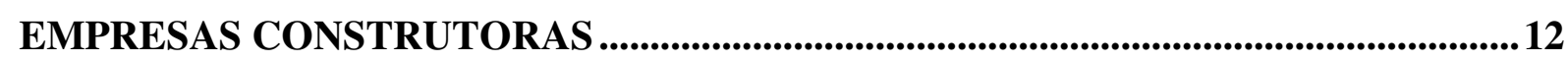

2.1 GESTÃO DO PROCESSO DE PLANEJAMENTO: DEFINIÇÕES ......................................... 13

2.1.1 Definições: gestão, gerenciamento, processo e planejamento.......................... 13

2.1.2 Estrutura organizacional orientada por processos......................................... 23

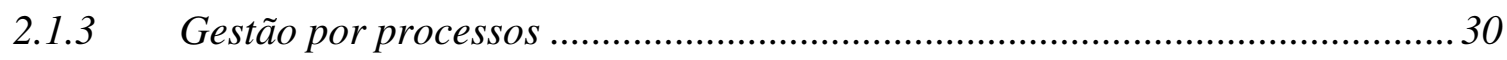

2.2 CARACTERIZAÇÃO DO PROCESSO DE PLANEJAMENTO DA PRODUÇÃO.......................... 33

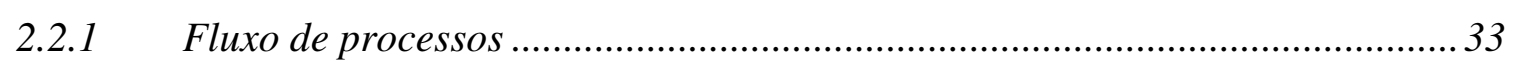

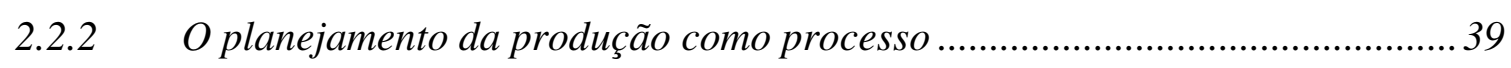

2.2.3 Análise de interfaces e integração entre processos............................................ 53

2.2.4 Gestão do processo de planejamento da produção.......................................... 65

2.2.5 A subcontratação do processo de planejamento da produção........................... 66

2.2.6 Competência do planejamento e competência de gestão ...................................6 68

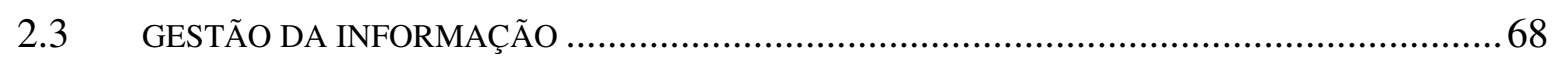

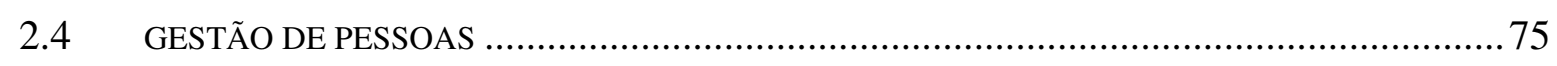

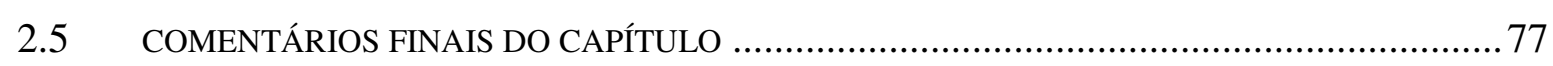

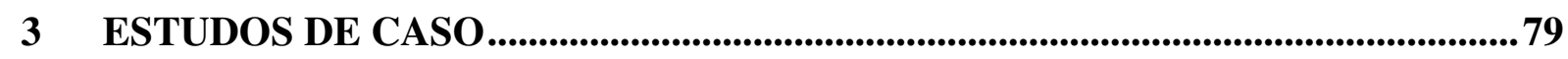

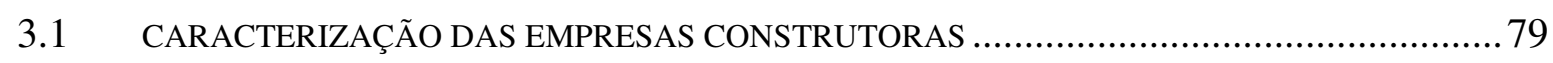

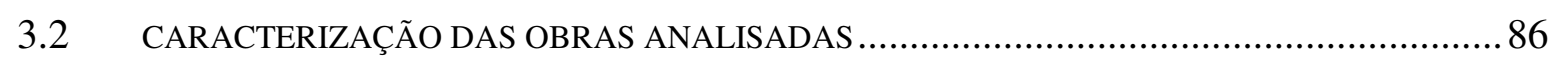


3.3 O PROCESSO DE PLANEJAMENTO DA PRODUÇÃO NAS EMPRESAS CONSTRUTORAS ...... 90

3.3.1 O processo de planejamento da produção na empresa A ............................... 91

3.3.2 O processo de planejamento da produção na empresa $B$................................ 98

3.3.3 O processo de planejamento da produção na empresa C.............................. 103

3.4 GESTÃO E INTEGRAÇÃO DO PROCESSO DE PLANEJAMENTO DA PRODUÇÃO ................ 107

3.5 PROPOSTA DE AÇÕES DE MELHORIA NA GESTÃO E INTEGRAÇÃO DO PROCESSO DE

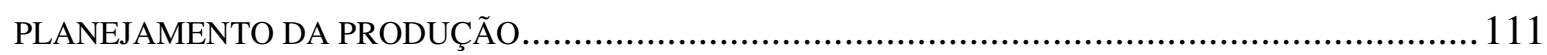

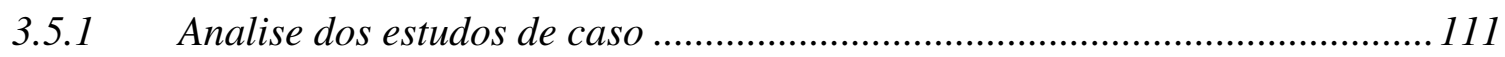

3.5.2 Práticas bem sucedidas e propostas de ações de melhoria............................. 122

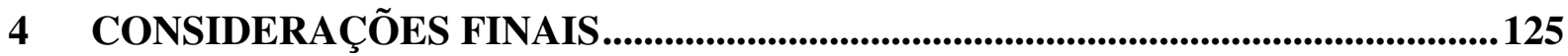

ANEXOS ..................................................................................................................................... 128

REFERÊNCIAS BIBLIOGRÁFICAS .............................................................................. 145 
Figura 1.1 - Etapas da pesquisa $\quad 9$

Figura 2.1 - Processo (ABNT, 2000) 15

Figura 2.2 - Sistema de planejamento 19

Figura 2.3 - Níveis do planejamento: programação e controle (LIMA JR., 1978) 20

Figura 2.4 - Processo de planejamento: dimensão horizontal (LAUFER e TUCKER, 1987) 21

Figura 2.5 - Aspectos a serem considerados na formação de uma estrutura organizacional 24 (adaptado de Vasconcellos e Hemsley (1997))

Figura 2.6 - Estrutura tradicional funcional departamentalizada e estrutura gerenciada por 28 processos (adaptado de Contador (1997))

Figura 2.7 - Cadeia de processos (ABNT, 2000) 33

Figura 2.8 - Fases e atividades de um empreendimento (SOUZA, 2001) 37

Figura 2.9 - Simbologia adotada para o fluxo de processos 39

Figura 2.10 - Processo de planejamento da produção 40

Figura 2.11 - Ciclo do planejamento (VARALLA, 2003)

Figura 2.12 - Gestão e integração do processo de planejamento da produção no fluxo de 54 processos principais da empresa

Figura 2.13 - Os sete estágios do processo de comunicação (adaptado de Calvert, Coles e Bailey (1995))

Figura 3.1 - Organograma da empresa A em junho de 2005

Figura 3.2 - Organograma da empresa B em julho de 2005

Figura 3.3 - Organograma da empresa C em abril de 2006

Figura 3.4 - Organograma da obra A em abril de 2006

Figura 3.5 - Organograma da obra B em abril de 2006

Figura 3.6 - Organograma da obra C em abril de 2006

Figura 3.7 - Processo de planejamento da produção da empresa A

Figura 3.8 - Processo de planejamento da produção da empresa B 


\section{LISTA DE FIGURAS}

Figura 3.9 - Processo de planejamento da produção da empresa C

Figura 3.10 - Fluxo do processo de planejamento da produção e interfaces - empresa A

Figura 3.11 - Fluxo do processo de planejamento da produção e interfaces - empresa B

Figura 3.12 - Fluxo do processo de planejamento da produção e interfaces - empresa C 


\section{LISTA DE TABELAS}

Tabela 3.1 - Caracterização das empresas construtoras 
Quadro 2.1 - Hierarquias do planejamento

Quadro 2.2 - Análise da interface do processo de planejamento da produção e do processo comercial

comercial

Quadro 2.3 - Análise da interface do processo de planejamento da produção e do processo de projeto

Quadro 2.4 - Análise da interface do processo de planejamento da produção e do processo de suprimento

Quadro 2.5 - Análise da interface do processo de planejamento da produção e do processo financeiro

Quadro 2.6 - Análise da interface do processo de planejamento da produção e do processo de entrega de obra e assistência técnica

Quadro 2.7 - Análise da interface do processo de planejamento da produção e do processo produtivo 


\section{LISTA DE ABREVIATURAS}

CPM - Critical Path Method

Cyclone - CYCLic Operations Network

EAP - Estrutura Analítica de Projeto

LOB - Line of Balance

PDCA - Plan, Do, Check, Act

PEO - Preparação da Execução de Obras

PERT - Program Evaluation and Review Technique

RMSP - Região Metropolitana de São Paulo

TCPO - Tabela de Composições de Preços para Orçamentos

TPS - Toyota Production System

UFSCar - Universidade Federal de São Carlos

UNICAMP - Universidade de Campinas

USP - Universidade de São Paulo

WBS - Work Breakdown Structure 
Este trabalho pretende contribuir com a caracterização e análise crítica da gestão dos processos nas empresas construtoras de edifícios, analisando especificamente a gestão e integração do processo de planejamento da produção em obras de edifícios residenciais de médio e alto padrão.

O presente trabalho é baseado em entrevistas com os principais agentes dos processos de empresas construtoras estudadas e revisão bibliográfica no tema. É realizada análise dos resultados destas entrevistas à luz dos conceitos referentes à gestão de produção, gestão de pessoas e gestão da informação, com foco na integração entre os processos, utilizando a análise do fluxo de atividades como ferramenta de estudo. Esta análise objetiva identificar os gargalos e desafios existentes, e os resultados já alcançados pelas empresas.

Como conclusão, foram identificados alguns pontos críticos na gestão do processo de planejamento da produção que interferem direta e indiretamente no desempenho dos empreendimentos, sob a ótica dos diversos autores estudados e dos gerentes entrevistados. Estes pontos críticos foram classificados e priorizados, e a partir deles são propostas ações de melhoria na gestão e integração do processo de planejamento da produção.

Palavras-Chave: gestão de processos, gestão da produção, planejamento, construção de edifícios 
This dissertation is a contribution to the characterization \& review of process management in general contractors, by undertaking in-depth analysis of the production planning process management and its integration into medium- and high-income residential buildings.

The research herein is based on several interviews with general contractors' major players of this process. The results from these interviews are analyzed up against the principles of production, people and information management. Focus is on integration amongst processes. Current study tool is the activity flow analysis. The analyses intent to point out existing gaps and challenges, and also to present preliminary results from those companies.

In conclusion there are some critical issues related to the production planning process management that do interfere directly and indirectly with the project performance, according to many referred authors and interviewed officers. These critical issues were arranged and set in order of priority, from there are proposed actions to improve the management and integration of the production planning process.

Keywords: process management, production management, planning, building construction 


\section{INTRODUÇÃO}

A presente pesquisa partiu do princípio de que as empresas construtoras ainda não dominam a gestão do processo de planejamento da produção, e que esta falta de domínio sobre o processo está afetando o desempenho de seus empreendimentos, e conseqüentemente, a competitividade da empresa construtora dentro do setor em que ela está inserida. Diante deste fato, surgiu a proposta de se entender como deve ser estruturado e organizado o processo de planejamento da produção de modo a permitir a gestão e integração deste processo aos demais processos do fluxo da empresa construtora.

Para fundamentar a importância desta pesquisa, recorreu-se à experiência de diversos estudiosos para apresentar nesta introdução a justificativa para o desenvolvimento desta pesquisa. Com base na problemática apresentada, são definidos os objetivos deste trabalho, bem como o plano para a sua elaboração.Também são apresentados os principais tópicos dos capítulos que formam este trabalho. Concluindo o capítulo, são estabelecidos o escopo e as limitações da pesquisa.

\subsection{JUSTIFICATIVA DA PESQUISA E IMPORTÂNCIA DO TEMA}

Muitos trabalhos vem sendo desenvolvidos apontando os problemas enfrentados por empresas construtoras no planejamento da produção de suas obras. De acordo com esses trabalhos, de modo geral, o planejamento é entendido como simplesmente a elaboração de um plano de ataque para a construção, sem a preocupação com o processo gerencial.

Bernardes (2001) aponta algumas das causas principais, citadas por outros autores, da ineficácia do processo de planejamento, e que motivam grande parte dos trabalhos de pesquisa que vem sendo desenvolvidos:

1) o planejamento da produção normalmente não é encarado como processo gerencial, mas como o resultado da aplicação de uma ou mais técnicas de preparação de planos e que, em geral, utilizam informações pouco consistentes ou baseadas somente na experiência ou intuição de gerentes (Laufer e Tucker, 1987);

2) o controle não é realizado de forma proativa e, geralmente, é baseado na troca de informações verbais do engenheiro com o mestre-de-obras, visando um curto prazo de 
execução e sem vínculo com o plano de longo prazo, resultando, muitas vezes, na utilização ineficiente de recursos (Formoso, 1991 apud Bernardes, 2001). Além da visão apenas do curto prazo, pode-se somar a preocupação com o caráter formal do planejamento apenas para cumprimento de requisitos, como certificação de sistema da qualidade, e para apresentação a órgãos financeiros e clientes;

3) a incerteza, inerente ao processo de construção, é freqüentemente negligenciada, não sendo realizadas ações no sentido de reduzi-las ou de eliminar seus efeitos nocivos (Cohenca et al., 1989). Isso pode ser evidenciado, principalmente, em situações nas quais os planos de longo prazo são muito detalhados. Nesses planos, a não consideração da incerteza e o excessivo detalhamento podem resultar em constantes atualizações dos mesmos (Laufer e Tucker, 1987);

4) com freqüência, existem falhas na implementação de sistemas computacionais para planejamento, por vezes adquiridos e inseridos em um ambiente organizacional, sem antes haver a identificação das necessidades de informações de seus usuários (Laufer e Tucker, 1987). Em geral, sem essa identificação, os sistemas produzem um grande número de dados irrelevantes ou desnecessários (Laufer e Tucker, 1987) que, normalmente, indicam apenas desvios das metas planejadas com as executadas e não as causas que provocaram tal desvio (Sanvido e Paulson, 1992). Além disso, tais sistemas são implantados, geralmente, de forma isolada nas empresas de construção, sem haver uma preocupação de estabelecer inicialmente uma integração entre eles (Bernardes, 1996) e, mesmo após a implementação, carecem de um programa de treinamento sistemático (Turner, 1993 apud Bernardes, 2001);

5) existem dificuldades de se mudar as práticas profissionais dos funcionários envolvidos com o planejamento, principalmente devido a formação obtida pelos mesmos nos cursos de graduação. Estes cursos, normalmente, focam nas ferramentas de programação, negligenciando as demais partes do processo (Laufer e Tucker, 1987; Oglesby et al, 1989 apud Bernardes, 2001).

Além das causas citadas por Bernardes (2001), também podem ser mencionadas outras falhas identificadas no processo de planejamento da produção das empresas construtoras, como a falta de integração e coordenação dos processos, a gestão deficiente e a indefinição das funções, responsabilidades e autoridades dos agentes. Estes problemas também motivam a realização deste trabalho de pesquisa. 
A falta de integração do processo de planejamento e demais processos da empresa construtora pode ser mencionada como uma das principais falhas na gestão. Esta falta de integração é tão preocupante que, segundo Souza (2001), um dos grandes desafios que os profissionais atuantes tanto no mercado público quanto privado têm que enfrentar é a efetiva coordenação entre as organizações, ou seja, as diversas empresas existentes no mercado e seus subcontratados e fornecedores, e entre as diferentes fases de um empreendimento, que compreende desde a montagem do empreendimento até a entrega, passando pelas fases de projeto, comercialização, execução e gestão do empreendimento.

Esta falta de coordenação e integração muitas vezes é criada pela própria estrutura da empresa. Melhado (1994) enfatizando a necessidade de mudança na gestão do sistema de produção dos empreendimentos, explica que isso implica em alterações estruturais, ou seja, demanda a revisão das organizações das empresas, a introdução de novos métodos de trabalho e uma melhor integração entre as várias atividades.

A importância da gestão é enfatizada por Souza (2001), que coloca o não cumprimento do cronograma físico, alterações no planejamento, atrasos na entrega do empreendimento, entre outros, como fatos comuns encontrados na construção de edifícios, e que são decorrentes de uma série de problemas de gestão, tais como: a falta de antecipação de decisões técnicas, causando modificações de último minuto; a espera por informações vitais para o andamento dos trabalhos nos canteiros de obras, conduzindo à tomada de decisões, envolvendo detalhes construtivos ou compra de material, sem o devido planejamento, acarretando problemas futuros e aumento do custo previsto.

A falta de definição clara do papel dos envolvidos também pode ser citada como uma das causas da ineficácia do processo. Em muitos processos da empresa, as funções, responsabilidades e autoridades se sobrepõem, até mesmo por falta de clareza na identificação e atribuição entre os agentes. A importância do indivíduo na organização e na gestão da empresa é comentada por Souza (2001), que coloca o conceito de organizações utilizado pelos sociólogos, onde se verifica que o elemento chave da organização é o indivíduo, ou seja, o agente. Souza (2001) ainda reforça que "o agente é considerado como peça chave para o sucesso da organização. Em torno dos agentes nascem as trocas de informações, as relações de trabalho, a cooperação, as estratégias e os métodos de trabalho".

Com a implantação de sistemas de gestão da qualidade nas empresas construtoras, baseados nas normas NBR ISO 9000, na sua versão 2000, essa questão da identificação das funções e 
atribuições de responsabilidades e autoridades melhorou bastante, visto que são desenvolvidos procedimentos que regularizam e padronizam os processos. No entanto, mesmo com a padronização dos processos, muitas vezes os papéis dos agentes dentro de uma empresa, principalmente quanto à liderança e poder de decisão, não são claros. Com isso, as interferências na gestão podem persistir.

Juntamente à falta de definição clara das funções, responsabilidades e autoridades dos envolvidos, tem-se a forte subcontratação dos trabalhos, principalmente de projetos, planejamento e execução dos serviços de obra, nas empresas construtoras. Um dos motivadores das empresas para a subcontratação é a redução de custo administrativo, com a diminuição do quadro técnico interno. No entanto, nesta subcontratação dos serviços, muitas vezes, não há a preocupação com a integração deste profissional ou empresa contratado no empreendimento e na própria empresa. No processo de planejamento da produção, este agente é inserido no empreendimento muitas vezes com a obra já iniciada, ou em estágios já avançados de desenvolvimento de projeto. Não há interação entre os profissionais de planejamento e de projeto, bem como do primeiro com os demais envolvidos. Este agente subcontratado apenas fornece um plano de produção, e muitas vezes não chega a acompanhar a produção por ele próprio definida. Também, quando acompanha a produção, não possui poder de atuação. Ou seja, o planejador entra no cenário apenas como um "desenhista" da produção que já está sendo realizada pelo responsável pela obra.

A subcontratação dos serviços de construção, principalmente nas empresas que atuam na região metropolitana de São Paulo, é também uma prática bastante comum. Nestas empresas, em suas obras, geralmente é mantida apenas a equipe gerencial própria da construtora, com a contratação de subempreiteiros para a construção dos diversos sistemas. Muitas vezes, a despreocupação com a forma de contratação destes subempreiteiros e a falta de análise de escopos e interfaces entre os serviços, e conseqüentemente entre as equipes contratadas, causa um impacto negativo no desempenho do planejamento da produção do empreendimento. $\mathrm{Ou}$ seja, a falta de integração entre o processo de contratação e planejamento pode inserir restrições no gerenciamento do empreendimento.

Melhado (1994) afirma que "o projeto deveria ser capaz de subsidiar as atividades de produção em canteiro com informações de alto nível e que não poderiam ser igualmente geradas no ambiente da obra; a partir de um bom projeto, tornar-se-ia possível elaborar um planejamento e uma programação eficientes, assim como um programa efetivo de controle da 
qualidade para materiais e execução”. A mesma observação feita quanto à importância e função do projeto pode ser estendida ao planejamento da obra. Ou seja, assim como o projeto deve subsidiar as atividades de produção em canteiro, o planejamento da produção deve fazer a ponte entre os objetivos definidos para o empreendimento e o canteiro, através da tradução dos objetivos para metas de produção.

Segundo Lima Jr. (1999), a lógica de planejar deve ser entendida como um processo de planejamento que deve estar sempre acompanhado da equação de meios para atingir metas, dentro de objetivos definidos. Para tanto, é necessária a integração dos diversos processos da empresa de modo que os objetivos sejam claramente transmitidos a todos os envolvidos, e na busca das metas comuns.

Outra causa da ineficácia do processo de planejamento é a despreocupação com o custo, ou com o controle do custo, que a gestão deste processo pode trazer. Lima Jr. (1999) afirma que "a diminuição de custos do processo está fortemente vinculada com a qualidade dos sistemas de controle e da velocidade segundo a qual seus registros provocam ajustes no sistema de planejamento; quanto mais integrados os sistemas, (...) maior condição terá a empresa de se valer das informações de controle para decidir, no planejamento, nos níveis de riscos mais baixos. Isso confere qualidade aos processos, diminuindo custos, porque é da essência estrutural da produção na Construção Civil a necessidade de nivelar o uso dos recursos para atingir padrões de produtividade crescentes". Também ressalta que em "empresas com sistemas de planejamento e controle da produção ativos, de largo espectro e confiáveis, se permitem tomar decisões mais arrojadas, no conceito de aceitar menores margens de resultado em benefício de ganhos de escala de produção".

Melhado (1994) comenta a importância das fases iniciais do empreendimento: nestas primeiras fases as decisões tomadas são as que têm maior capacidade de influenciar o custo final. Também Hammarlund e Josephson (1992) apud Melhado (1994) defendem a idéia de que as decisões tomadas nas fases iniciais do empreendimento são importantes, atribuindolhes a principal participação na redução dos custos de falhas do edifício. Portanto, juntamente com o projeto e demais processos iniciais, o processo de planejamento tem fundamental importância na antecipação de situações possíveis de ocorrerem na fase de obra.

Segundo Paulson Jr. (1976) apud Bernardes (1996), o impacto do custo da realização do planejamento representa menos de $1 \%$ do valor total do empreendimento, enquanto que os 
benefícios resultantes da tomada de decisões antes de se iniciar a construção podem trazer uma economia da ordem de $25 \%$ do custo total da construção.

Isto posto, esta pesquisa é motivada pelos problemas enfrentados nas empresas construtoras na integração dos processos e, em especial, na gestão do processo de planejamento da produção.

\subsection{OBJETIVOS}

A partir da problemática de pesquisa apresentada, foram propostos os objetivos demonstrados a seguir.

\subsubsection{Objetivo Global}

O objetivo global desta dissertação é caracterizar e analisar criticamente, com base em revisão bibliográfica e estudos de caso, a gestão do processo de planejamento da produção em empresas construtoras de médio e grande porte, em empreendimentos residenciais de médio e alto padrão.

Para tanto, num primeiro momento, objetivou-se identificar as atividades administrativas, gerenciais e operacionais envolvidas no processo de planejamento da produção, e como estas atividades são gerenciadas, e integradas com os demais processos da empresa construtora sob a ótica de diversos autores que já estudaram o assunto. A partir da caracterização teórica do processo de planejamento da produção, buscou-se analisar e confrontar este processo teórico com o processo prático existente nas três empresas construtoras da Região Metropolitana de São Paulo pesquisadas. Por esta análise é possível discutir sobre os gargalos e desafios existentes na gestão do processo de planejamento da produção, e os resultados já alcançados pelas empresas.

\subsubsection{Objetivos Parciais}

Também foram definidos objetivos parciais para esta pesquisa, que são:

(1) caracterização do processo de planejamento da produção 
(2) análise da integração do processo de planejamento da produção com os demais processos da empresa construtora: comercial, projeto, financeiro, suprimento, execução, entrega final e assistência técnica;

(3) análise do impacto da subcontratação do planejamento da produção;

(4) identificação do fluxo de informações no processo de planejamento da produção e interfaces, e os modelos aplicados na gestão da informação e do conhecimento;

(5) proposição de melhorias que poderiam ser implementadas na gestão do processo de planejamento.

\subsection{MÉTODO DE PESQUISA E REDAÇÃO DA DISSERTAÇÃO}

\subsubsection{Método de pesquisa}

A partir da definição dos objetivos desta pesquisa, foi estabelecido um plano para a realização do trabalho, com as seguintes etapas, desenvolvidas de forma interativa e ilustrado na figura 1.1:

(1) revisão bibliográfica, abrangendo teses, dissertações, livros, artigos de revistas e de congressos. Através desta revisão bibliográfica buscou-se caracterizar o modelo de gestão do processo de planejamento da produção em empresas construtoras.

Para desenvolver a revisão bibliográfica foram realizadas pesquisas e seleção de materiais nacionais e internacionais nos acervos em meio físico e eletrônico das seguintes bibliotecas: da Escola Politécnica da USP, da Faculdade de Economia, Administração e Contabilidade da USP, da Faculdade de Engenharia Civil da UNICAMP, da Faculdade de Engenharia Civil da UFSCar, do NORIE ${ }^{1}$ da Universidade Federal do Rio Grande do Sul, da Universidade Federal Fluminense, da Universidade Federal de Santa Catarina.

Também foram consultados anais de congressos e artigos publicados em periódicos, disponíveis nos sites: <<www.infohab.org.br >>, <<www.periodicos.capes.gov.br >> e $<<$ www.usp.br/sibi >>.

\footnotetext{
${ }^{1}$ NORIE - Núcleo Orientado para a Inovação da Edificação
} 
A análise dos conceitos teóricos permitiu capacitar e preparar a pesquisadora, mas também demonstrou que seria necessária uma segunda etapa no desenvolvimento deste trabalho, que é a análise crítica de como as empresas construtoras estão gerenciando seus processos de planejamento da produção, e de como os estudos teóricos já estão sendo aplicados ou ainda podem contribuir para a melhoria dos processos das empresas.

(2) pesquisa de campo, para o estudo de empresas construtoras de médio e grande porte, que atuam em empreendimentos residenciais de médio e alto padrão, na Região Metropolitana de São Paulo, analisando os aspectos gerenciais do processo de planejamento da produção e a integração com os demais processos da empresa.

Para a seleção das empresas e dos empreendimentos pesquisados, foram levadas em consideração as informações prévias sobre a organização e o modelo de gestão que estas empresas já mantém em seus processos. Partiu-se do princípio de que as empresas tinham que, pelo menos, ter uma estrutura de gestão de trabalho bem definida (estrutura organizacional, fluxo de processos, procedimentos operacionais, processo de planejamento operacional definido e estabelecido). Por isso a delimitação da pesquisa em empresas construtoras de médio e grande porte, visto que as pequenas empresas, na maioria das vezes, não possuem formalização da organização de seus processos.

A escolha de empreendimentos residenciais de médio e alto padrão deu-se pelo fato de que, neste tipo de obra, muitas são as interferências decorrentes de detalhes de projeto e acabamento, bem como a personalização dos apartamentos, prática que se difundiu nas empresas construtoras nos últimos anos como apelo de marketing. Com isso, a gestão do processo de planejamento da produção das obras se torna ainda mais problemática.

Também foi considerada, por questões práticas, a proximidade das empresas, por isso a delimitação na Região Metropolitana de São Paulo, e a disponibilidade destas empresas para fornecer informações e participar de entrevistas.

Para a condução das pesquisas de campo, foi considerando que o processo de planejamento da produção está estruturado em dois subprocessos principais - um subprocesso que está instalado no fluxo de processos principais da empresa; e um subprocesso integrante do fluxo de processos do empreendimento ${ }^{2}$. A pesquisa de campo foi estruturada de modo que os

\footnotetext{
${ }^{2}$ A discussão sobre a formação do processo de planejamento da produção por dois subprocessos é apresentada no capítulo 2 deste trabalho.
} 
agentes dos subprocessos fossem entrevistados, sendo possível a coleta de dados de todos os envolvidos. Portanto, foram realizadas visitas no escritório e em uma das obras da empresa para observação e aplicação de questionários. A obra selecionada deveria atender aos critérios definidos no escopo desta pesquisa.

Os questionários aplicados apresentam um roteiro semi-estruturado de entrevista, contendo os temas-chave para discussão (ver anexo, ao final da dissertação), permitindo maior flexibilidade na obtenção de respostas de cada entrevistado, uma vez que se busca explorar a ocorrência e as possibilidades de um fenômeno ou prática, sem se importar com a quantificação do fenômeno e com a extrapolação dos resultados para um universo maior de situações.

(3) redação da dissertação, apresentando os resultados e propondo melhorias através da análise crítica da forma como as empresas construtoras estão gerenciando o processo de planejamento, bem como integrando este processo com os demais, à luz dos conceitos obtidos no estudo bibliográfico.

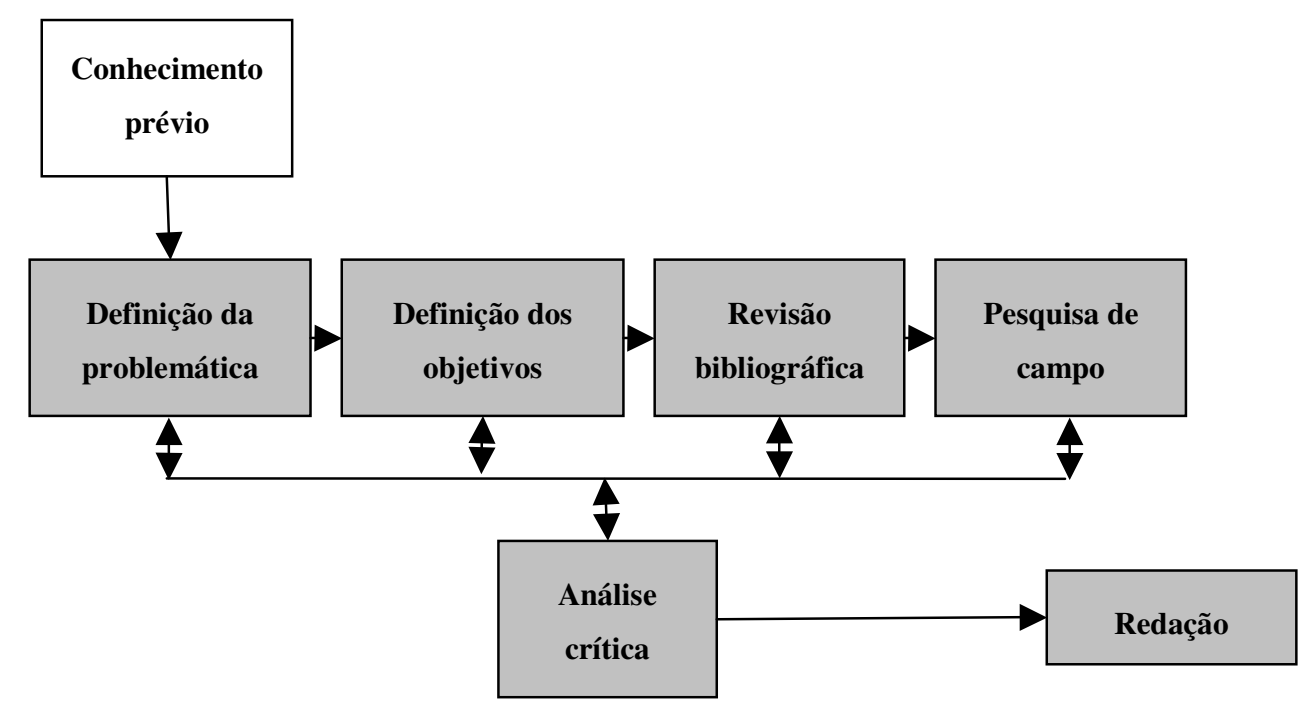

Figura 1.1 - Etapas da Pesquisa

\subsubsection{Estruturação do trabalho}

Este trabalho está estruturado em quatro capítulos, apresentados brevemente a seguir. 
O primeiro capítulo - Introdução - apresenta o estudo inicial para a definição do tema, discussão das justificativas, definição dos objetivos (global e parciais), definição do plano de pesquisa, estruturação do trabalho, delimitação do escopo e limitações.

O segundo capítulo - Gestão do processo de planejamento da produção em empresas construtoras - consiste na revisão bibliográfica realizada, caracterizando os modelos de gestão de processos, com enfoque principal na gestão do processo de planejamento da produção. Nesse capítulo também são discutidos os conceitos de fluxo de informações, gestão do conhecimento e gestão de pessoas, temas complementares na análise crítica da gestão dos processos principais.

O terceiro capítulo - Estudos de caso - descreve os estudos de caso realizado nas três empresas construtoras, bem como em uma de suas obras. A partir da caracterização dos estudos de caso, é realizada uma reflexão sobre como as empresas construtoras estão gerenciando seus processos de planejamento da produção, e como tratam a integração do processo aos demais processos de seus fluxos. A partir desta reflexão são classificados os pontos fortes e fracos na gestão e integração do processo de planejamento da produção nas empresas construtoras, e são propostas ações de melhoria.

O quarto capítulo - Considerações finais - traz as conclusões alcançadas com esta pesquisa. Após este capítulo, há ainda os anexos da pesquisa (questionários de pesquisa de campo) e, por último, as referências bibliográficas que sustentam as constatações do trabalho.

Todos os capítulos são iniciados por um preâmbulo, destacado no texto em itálico, com uma breve apresentação da problemática que será abordada no decorrer do capítulo e a metodologia utilizada.

Ao longo do texto podem ser apresentados elementos de apoio para complementar e auxiliar o raciocínio desenvolvido ao longo do trabalho, como figuras, quadros e tabelas. Nas tabelas são apresentadas relações quantitativas sobre determinado aspecto estudado. Os quadros apresentam sínteses de conceitos e informações na forma de texto. As figuras apresentam ilustrações e desenhos esquemáticos. 
A configuração da página, a formatação e a forma de apresentação das referências bibliográficas seguem as "Diretrizes para apresentação de dissertações e teses da USP: documento eletrônico e impresso" do Serviço de Bibliotecas da Escola Politécnica da USP³.

\subsection{ESCOPO E LIMITAÇÕES DO TRABALHO}

O enfoque do presente trabalho é a análise da gestão do processo de planejamento da produção em empresas construtoras, com ênfase na integração do processo de planejamento da produção com os demais processos da empresa construtora.

Não se pretende modelar o processo de planejamento ideal para empresas construtoras, visto que cada empresa apresenta um fluxo de processos particular. Sendo assim, aqui cabe a análise do fluxo de processos das empresas analisadas à luz dos conceitos estudados na revisão bibliográfica, e a proposição de um modelo para diagnóstico do processo de planejamento para aplicação em outras empresas construtoras deste segmento, bem como a identificação de pontos críticos para a análise e implantação de melhorias.

Também não se objetiva a discussão de ferramentas de programação e controle de obras, pois muitos trabalhos foram realizados discutindo a aplicação das diversas ferramentas disponíveis, e podem ser utilizados como referência para a complementação deste estudo. Cabe ressaltar que a aplicação eficiente de boas ferramentas só é possível desde que sejam gerenciadas e estejam integradas aos processos.

3 UNIVERSIDADE DE SÃO PAULO. Escola Politécnica. Serviço de Bibliotecas. Diretrizes para apresentação de dissertações e teses da USP: documento eletrônico e impresso. São Paulo, 2003. 


\section{GeSTÃo do PRocesso de PLANEJAMENTO DA PROduÇão EM EMPRESAS CONSTRUTORAS}

Neste capítulo são apresentados os conceitos envolvidos na gestão do processo de planejamento da produção. Para tanto, são apresentadas as definições de diversos estudiosos dos temas relacionados.

Para entender a gestão por processos, primeiramente são apresentados os conceitos de estrutura organizacional e a comparação entre a organização da empresa estruturada tradicionalmente, e a empresa que busca modos de estruturação mais inovadores, orientada por processos. Com isso, são discutidos os conceitos da gestão por processos, inclusive a aplicação pelos sistemas de gestão da qualidade, implementados em empresas construtoras.

A partir desta análise introdutória, são discutidos os conceitos de fluxo de processos e a visão do planejamento da produção como um processo da empresa construtora típica, inserido em seu fluxo principal de processos. Na análise da participação do processo de planejamento da produção no fluxo, são verificadas as diversas interfaces deste processo e como este pode ser integrado aos demais processos, como comercial, projetos, suprimento, financeiro e entrega de obra.

Pela percepção de que em uma organização a gestão é fundamental para o seu desenvolvimento e na sua competitividade, e que a gestão deve ser aplicada globalmente, na organização como um todo, e localmente em cada processo, são discutidas as características da gestão do processo de planejamento da produção.

Como análises complementares, também são apresentados os aspectos da subcontratação do planejamento da produção nas empresas construtoras, a diferenciação entre as competências do planejamento como processo, e as competências da gestão deste processo.

Considerando que a informação e o papel dos agentes é fundamental na gestão do processo de planejamento da produção, são também discutidas a gestão da informação e a gestão de pessoas.

Finalizando, é apresentada a conclusão do capítulo, com as principais impressões sobre os assuntos discutidos e a sua relevância para este trabalho. 


\subsection{GESTÃO DO PROCESSO DE PLANEJAMENTO: DEFINIÇÕES}

\subsubsection{Definições: gestão, gerenciamento, processo e planejamento}

Os termos "gestão", "gerenciamento", "processo" e "planejamento" serão utilizados ao longo deste trabalho, sendo apresentada, nesta seção, uma breve introdução a estes termos.

Cardoso (1997b) destaca que a atividade de "gestão" envolve uma pluralidade de ações, que são: a) a planificação, ou seja, organização das atividades no tempo, previsão, antecipação; b) a organização, o que implica na identificação das competências necessárias para a realização das atividades, na definição dos limitantes do desenvolvimento, na definição e obtenção dos recursos, na previsão das interfaces e na coordenação do conjunto dessas atividades; c) a direção, com a definição dos objetivos, a transmissão das informações, a tomada de decisão, a transparência, o comprometimento das pessoas que participam do processo, a cooperação; d) o controle, através de indicadores que tornem possível a tomada de ações corretivas.

A abordagem do termo "gestão" evoluiu com a origem do termo "gestão da qualidade" na década de 90. Dentre os trabalhos realizados no ambiente da gestão da qualidade, a gestão é definida por Picchi (1993) como a forma pela qual as organizações planejam, definem, obtêm, controlam e melhoram evolutivamente suas ações em busca da qualidade.

Ainda no ambiente da gestão da qualidade, a norma NBR ISO 9001, na sua versão 2000, identifica a gestão dos produtos e processos como sendo a aplicação da metodologia conhecida como PDCA (Plan, Do, Check, Act). O modelo PDCA, como definido em ABNT (2000), pode ser descrito como: plan, planejar, com o estabelecimento dos objetivos e dos processos necessários para fornecer resultados de acordo com os requisitos do cliente e políticas da organização; do, fazer, com a implementação dos processos anteriormente estabelecidos; check, checar, com o monitoramento e medição dos processos e dos produtos em relação às políticas, aos objetivos e aos requisitos para o produto, e comunicação dos resultados; act, agir, com a execução das ações para promoção contínua da melhoria do desempenho do processo. Segundo Picchi (1993) e Souza (1997) a função do modelo PDCA é servir como um instrumento de controle e melhoria do processo na gestão da organização.

Neste trabalho, o termo "gestão" é adotado como sendo o conjunto de ações de planejamento, organização das competências, responsabilidades e autoridades, comunicação, controle, tomada de decisão e melhoria. 
Quanto ao termo "gerenciamento", existe forte correspondência com o termo "gestão". Isto pode ser verificado pela definição de Lima Jr. (1990b), que apresenta o gerenciamento como um conjunto de atividades que vão desde o planejamento, a coordenação de projetos, a fiscalização e a supervisão das atividades até as rotinas administrativas.

Halpin e Woodhead (2004) já apresentam uma definição mais restritiva para gerenciamento, como sendo o planejamento e o controle dos recursos relativos a um sistema de produção. $\mathrm{O}$ sistema de produção, para os autores, envolve desde o desenvolvimento do projeto até a produção do bem em si.

Estes mesmos autores complementam com a explicação de que o gerenciamento da construção é a aplicação mais eficiente, pelo gerente, dos recursos disponíveis. Os recursos para a construção são caracterizados como os quatro $M s$ da construção, que são: manpower (força humana), machines (máquinas e equipamentos), materials (materiais) e money (dinheiro). Portanto, o gerenciamento, ou seja, o planejamento e controle dos recursos, compreende a aplicação oportuna e eficiente dos quatro Ms em um sistema de produção.

Próxima à definição de gerenciamento por Lima Jr. (1990b), tem-se a definição apresentada por Ahuja (1994), que diz que gerenciar envolve planejamento, organização, execução e monitoramento. Este autor ainda enfatiza que o gerenciamento deve ser proativo, e que entre todos os fatores considerados, os elementos humanos não podem ser esquecidos.

Processo, na gestão da qualidade, pela ABNT (2000), é "uma atividade que usa recursos e que é gerenciada de forma a possibilitar transformação de entradas em saídas" (Figura 2.1). A norma também introduz o conceito de abordagem de processos quando coloca que "para uma organização funcionar de maneira eficaz, ela tem que identificar e gerenciar diversas atividades interligadas", ou seja, seu fluxo de processos, e sendo possível o controle "sobre a ligação entre os processos individuais dentro do sistema de processos, bem como sua combinação e interação". 


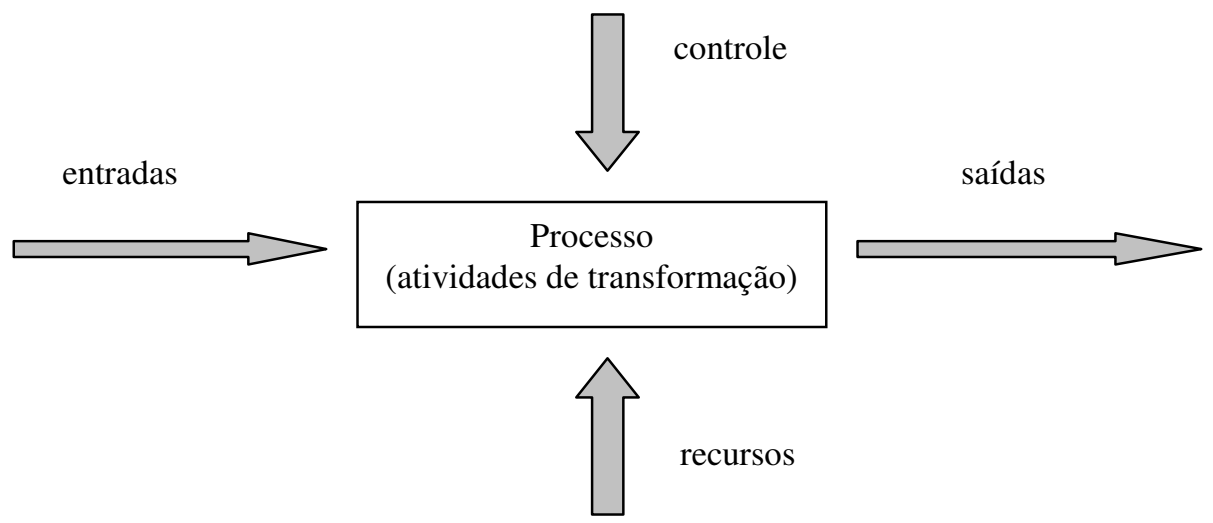

Figura 2.1 - Processo (ABNT, 2000)

Além da definição de "processo" apresentada pela norma de gestão da qualidade, diversos autores que pesquisam sobre temas como reengenharia de processos, gestão de operações e sistemas de gestão organizacional também procuram definir o termo "processo". Como Davenport (1994), que define processo como "um conjunto de atividades estruturadas no tempo e no espaço, com um começo, um fim, entradas e saídas claramente definidas". O autor ainda complementa que o processo "representa uma estrutura para ação, com ênfase na maneira como o trabalho é realizado na empresa".

Contador (1997) define o termo processo como sendo o agrupamento de atividades organizadas e executadas seqüencialmente, que transformam recursos (informações, mão-deobra, material, fornecedor) em produtos ou serviços que agregam valor ao cliente, sendo caracterizado pela relação de interdependência entre clientes e fornecedores internos (departamentos).

Dentre os pesquisadores de gestão organizacional, Harrington (1993) define processo como sendo "qualquer atividade que recebe uma entrada (input), agrega-lhe valor e gera uma saída (output) para um cliente interno ou externo". O autor ainda complementa dizendo que "os processos fazem uso dos recursos da organização para gerar resultados concretos”. Este mesmo autor apresenta o conceito de processo em duas esferas: dos processos produtivos e dos processos empresariais. Processo produtivo seria "qualquer processo que entra em contato físico com o produto ou serviço que será fornecido a um cliente externo", e processo empresarial seriam "todos os processos que geram serviço e os que dão apoio aos processos produtivos". 
Cardoso (1997b) apresenta uma definição para processo de produção como sendo "conjunto das etapas físicas, organizadas de forma coerente no tempo, que levam à construção e ao uso de uma edificação. Tal processo engloba atividades de projeto, planejamento, de execução e de avaliação pós-ocupacional".

Salerno (1998) comenta que tanto no âmbito das organizações quanto nos trabalhos de pesquisa realizados há uma grande variedade de respostas e conceitos subjacentes para o termo "processo". Para o autor, processo é "uma cooperação de atividades distintas para a realização de um objetivo global, orientado ao cliente final que lhes é comum". O autor complementa que correspondem a um processo: um desempenho, que formaliza o seu objetivo global (nível de qualidade, prazo de entrega, etc); uma organização, que materializa e estrutura transversalmente a interdependência das atividades do processo, durante sua duração; uma co-responsabilidade dos agentes nesta organização, com relação ao desempenho global; e uma responsabilidade local de cada agente em sua própria atividade.

Portanto, para este mesmo autor, um processo possui as seguintes características:

a) uma organização estruturada, constituída pela ligação ao cliente final;

b) entradas tangíveis ou intangíveis;

c) saídas, ou resultado do processo;

d) recursos, ou a utilização eficiente dos recursos, ou seja, a utilização dos recursos localmente necessários e úteis ao processo;

e) custos, relacionados aos recursos globais;

f) desempenho global, mensurado através de indicadores locais para cada atividade integrante do processo, de modo a tornar possível a avaliação sobre o resultado do processo e identificação das co-responsabilidades;

g) fatores de desempenho, ou pontos críticos do processo, que podem ser atividades ou coordenações; e

h) desenrolar temporal, ou duração do processo e localização no tempo, visto que o processo acontece com temporalidade organizável e mensurável.

Portanto, o termo "processo" será adotado como sendo um conjunto de atividades estruturadas e organizadas no tempo, atribuídas aos agentes envolvidos, com início e término determinados, que utilizam recursos (materiais, pessoas, informações etc) através da aplicação 
de métodos, para produzir saídas (produtos, serviços ou informações), e que são orientadas pelas necessidades dos clientes internos dos processos seguintes e, principalmente, do cliente final.

Quanto à definição de "planejamento", cabe uma primeira colocação, que é a apresentação do sistema de planejamento como sendo formado por dois subsistemas: subsistema de programação e subsistema de controle. Estes dois subsistemas são complementares e necessários, e o desenvolvimento e aplicação dos dois subsistemas caracterizam o processo como um todo. A discussão sobre a participação dos dois subsistemas e a importância de cada um deles será apresentada na seção 2.2.2.

De acordo com Cleland (1988), planejamento é o processo de pensar, e tornar explícito os objetivos, metas, e estratégias necessárias para executar um empreendimento dentro do seu ciclo de vida, atendendo os requisitos de custo, prazo e objetivos de desempenho técnico.

Segundo Ackoff (1970) apud Cardoso (1997b), “planejamento é um processo de decisão executado anteriormente à ação, e se propõe a estabelecer o futuro desejado e meios efetivos para que este se realize". Para tanto, o planejamento deve responder às seguintes questões: o que deve ser feito (atividades); como deve ser feito (métodos); quem deve executar cada atividade e com que meios (recursos); e quando as atividades devem ser executadas (seqüência e duração). Ou seja, como definido por Varalla (2003), planejamento é "um processo de previsão de decisões, que envolve o estabelecimento de metas e a definição dos recursos necessários para atingi-las". Portanto, o planejamento não fornece dados que podem ser considerados definitivos e, sim, um conjunto de diretrizes para a ação, como comentado por Varalla (2003).

Muitos trabalhos apresentados sobre o tema planejamento, como de Lima Jr. (1978), Laufer e Tucker (1987), Assumpção (1996), Martins (1998), Silva (1999), Bernardes (2001), entre outros, apresentam o planejamento dividido em três níveis, quais sejam: planejamento estratégico, planejamento tático, e planejamento operacional. Esta estrutura do processo de planejamento é adotada pelo grupo de pesquisa GEPE-GER ${ }^{4}$ da Escola Politécnica da Universidade de São Paulo, e será considerada neste trabalho.

\footnotetext{
${ }^{4}$ GEPE-GER é a área de concentração de pesquisa em gerenciamento de empreendimentos do Departamento de Engenharia de Construção Civil e Urbana da Escola Politécnica da Universidade de São Paulo.
} 
Conforme definição de Assumpção (1996), o planejamento estratégico está situado no maior nível da hierarquia de uma organização, e possui como função a manipulação dos dados e geração de informações com a visão global da empresa, e sempre tendo em vista a interface com o mercado, analisando alternativas de investimentos para atingir os objetivos de longo prazo. Já o planejamento tático está situado na esfera do negócio e subsidia decisões que levam à escolha dos empreendimentos a serem implementados. Direcionado para cada empreendimento da organização está o planejamento operacional, que discute em sua hierarquia superior as estratégias e metas de produção, e em uma hierarquia inferior define o planejamento das operações e ordens de produção (Quadro 2.1).

Quadro 2.1 - Hierarquias do planejamento

\begin{tabular}{|l|l|}
\hline Planejamento estratégico & $\begin{array}{l}\text { Nível superior da hierarquia da organização } \\
\text { Manipulação de dados e geração de informações com a visão global } \\
\text { Análise da interface com o mercado }\end{array}$ \\
\hline Planejamento tático & $\begin{array}{l}\text { Situado na esfera do negócio } \\
\text { Subsidia decisões que levam à escolha dos empreendimentos }\end{array}$ \\
\hline Planejamento operacional & $\begin{array}{l}\text { Direcionado para cada empreendimento } \\
\text { Trata das estratégias e metas de produção em sua hierarquia superior } \\
\text { e das operações e ordens de produção na hierarquia inferior }\end{array}$ \\
\hline
\end{tabular}

Este mapeamento da hierarquia do planejamento deixa claro que a estratégia de produção, definida no planejamento operacional, "além de ser coerente sob o ponto de vista da produção, nos aspectos de melhor aproveitamento dos recursos ou mesmo de organização do canteiro, deve ser voltada para a viabilidade do empreendimento [planejamento tático] e para os resultados da empresa [planejamento estratégico]”, conforme explicação de Assumpção (1996). Portanto, o planejamento deve ser elaborado e implementado nos três níveis, que possuem necessidades específicas de informação e controle, mas devem formar um conjunto único e sincronizado.

Muitos autores também apresentam os níveis do planejamento operacional. Como discutido por Fachini (2005), o planejamento operacional é formado por três grandes áreas de decisões: decisões de longo prazo, decisões de médio prazo e decisões de curto prazo. Como colocado 
pela autora, as decisões de longo prazo "são bastante abrangentes, tratando de questões sobre a forma de se produzir o produto, a localização do sistema produtivo e de suas partes, o dimensionamento da capacidade produtiva e os momentos em que esta capacidade deve ser ampliada". A autora ressalta que as decisões de longo prazo são "elementos condicionantes ou limitantes operacionais da forma pela qual o sistema produtivo deverá ser operado nos níveis de médio e curto prazo".

As decisões de médio prazo, também segundo Fachini (2005), tratam da alocação dos recursos, como a programação de materiais e mão-de-obra (quantidade e momento de utilização), e estoques necessários e possíveis na obra, sendo esta alocação de recursos a cada pacote de trabalho. Neste nível, as decisões de longo prazo condicionam ou limitam a disponibilidade dos recursos. Por sua vez, as decisões de médio prazo são as restrições das decisões de curto prazo. As decisões de curto prazo definem a produção diária, os recursos alocados a cada tarefa e a prioridade das tarefas.

Assumpção (1996) comenta que, em todos os níveis da hierarquia, "a essência do processo de planejamento consiste na construção de modelos que representem as relações entre as variáveis ou atividades que se desenvolvem no ambiente da empresa e de seus empreendimentos, aliado a sistemas, que permitem operar com estes modelos e gerar informações, ora na forma de expectativas de comportamento do modelo (diretrizes para ação), ora avaliando o comportamento das ações já empreendidas (monitoração dos resultados)" (Figura 2.2).

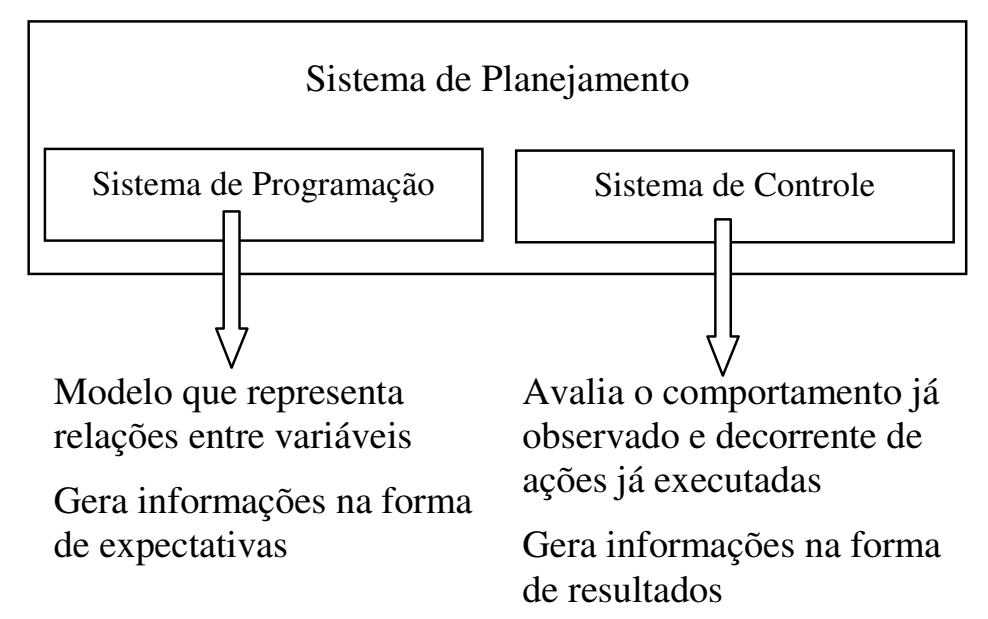

Figura 2.2 - Sistema de Planejamento 
Portanto, em qualquer das esferas de planejamento, este é formado por um subsistema de programação, que consiste no modelo que representa as relações entre as variáveis, e gera informações na forma de expectativas de comportamento, e por um subsistema de controle, que gera informações e avalia o comportamento já observado e decorrente de ações já executadas. Assim, segundo Lima Jr. (1978), "para cada nível do sistema de planejamento caracteriza-se um do sistema de controle" (Figura 2.3).

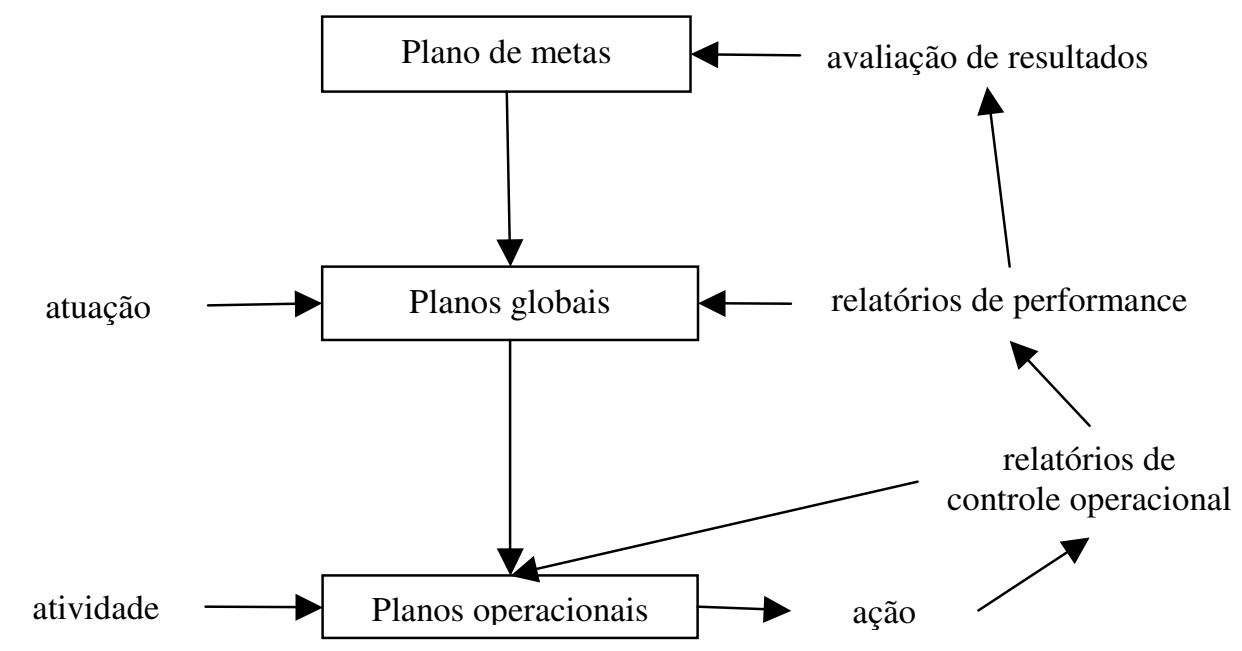

Figura 2.3 - Níveis do planejamento: programação e controle (LIMA JR., 1978)

Assumpção (1996) ainda coloca que "estes dois subsistemas [de programação e controle] interagem a partir de uma mesma matriz de informações, onde as diretrizes emanadas pelo sistema de programação induzem as medidas de desempenho que são processadas pelo sistema de controle. A interação entre estes dois subsistemas, através de um processo dinâmico de programação, controle e reprogramação, caracteriza o sistema de planejamento".

Este trabalho é desenvolvido no terceiro nível do planejamento, o planejamento operacional, que é direcionado para cada empreendimento da empresa, considerando as três esferas de decisão: longo, médio e curto prazo. Portanto, o termo "planejamento da produção", neste trabalho, é utilizado para denominar o planejamento operacional no longo, médio e curto prazo.

No entanto, como bastante salientado, não pode ser perdida a visão global do processo, que corresponde também aos outros dois níveis superiores, pois uma análise realizada apenas em 
um dos níveis, sem a preocupação com a integração do processo como um todo, pode gerar interpretações que são positivas localmente, mas negativas para a organização.

Também vale apresentar a definição de planejamento dada por Laufer e Tucker (1987). Estes autores apresentam o planejamento como um processo de tomada de decisão realizado para antecipar uma ação futura desejada, utilizando meios eficazes para isso. Os autores também colocam que os objetivos básicos do planejamento da produção são: auxiliar a gerência da organização; coordenar os diversos agentes envolvidos; tornar possível o controle da produção; e possibilitar a comparação entre diversos cenários, fundamentando a tomada de decisão.

Estes mesmos autores colocam que o planejamento pode ser representado em duas dimensões: dimensão horizontal e dimensão vertical. A dimensão horizontal é onde ocorre todo o desenvolvimento do processo de planejamento, e a dimensão vertical é onde o processo de planejamento é integrado aos diversos níveis gerenciais da organização.

A dimensão horizontal do processo de planejamento compreende cinco etapas: 1) planejamento do processo de planejamento; 2) coleta de dados; 3) preparação de planos (programação); 4) comunicação do planejamento; e 5) avaliação do processo de planejamento. A interação destas cinco fases é ilustrada na figura 2.4.

Ciclo do Planejamento

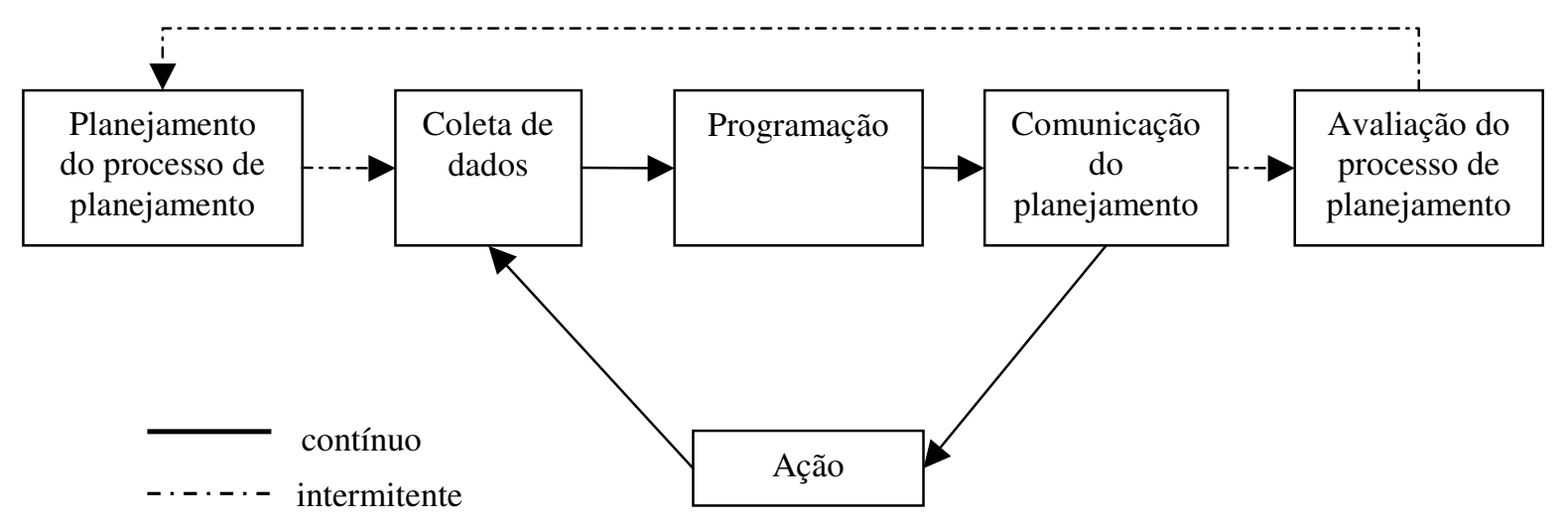

Figura 2.4 - Processo de planejamento: dimensão horizontal (LAUFER e TUCKER, 1987)

A primeira etapa, de preparação do processo de planejamento, consiste na tomada de decisões relativas ao horizonte e nível de detalhe do planejamento, freqüência de replanejamento, e o 
grau de controle que será empregado. É uma atividade intermitente pois acontece no ínicio de cada empreendimento, ainda no estudo de viabilidade.

A coleta de dados é importante pois é a fase onde as informações necessárias para se realizar o planejamento, com a estrutura já definida na primeira etapa, é realizada. Estas informações incluem contratos, projetos, requisitos do cliente, tipo da mão-de-obra que será utilizada, soluções tecnológicas, métodos construtivos, índices de produtividade, etc. Laufer e Tucker (1987) ainda reforçam que esta fase tem como objetivo reduzir as incertezas através da seleção das informações e consideração dos riscos envolvidos nas escolhas realizadas.

A terceira fase, de programação, consiste na elaboração dos planos de produção para o empreendimento. Esta fase, segundo os autores, é a que normalmente recebe mais ênfase nas empresas.

$\mathrm{Na}$ fase de comunicação do planejamento é quando o planejamento é transmitido aos envolvidos. Para tanto, a qualidade da informação e a maneira como esta é comunicada deve atender aos diversos níveis da hierarquia, sendo fundamental na garantia do envolvimento e comprometimento dos agentes.

Na fase da ação, o controle e monitoramento é implementado, e ações corretivas devem ser aplicadas para a compensação de eventuais desvios ${ }^{5}$. Esta fase também faz com que o ciclo do processo aconteça, com a necessidade de coleta de dados complementares, e possíveis reprogramações.

A última fase, a avaliação do processo de planejamento, é uma fase intermitente, que ocorre ao final do empreendimento, ou quando mudanças significativas no progresso da obra causam impacto no prazo, custo ou qualidade do empreendimento. Nesta fase, são analisados indicadores que avaliam o processo de planejamento e o desempenho do processo no empreendimento. Tanto esta última fase quanto a primeira são quase inexistentes nas empresas, como comentam Laufer e Tucker (1987).

A dimensão vertical integra o planejamento nos diversos níveis gerenciais da organização, de modo a manter os mesmos objetivos definidos globalmente pela empresa em todos os níveis hierárquicos. Cada nível do planejamento necessita de um certo grau de detalhamento, com este aumentando conforme se caminha para níveis hierárquicos inferiores. No entanto, o grau

\footnotetext{
${ }^{5}$ Conforme explicação de Assumpção (1996), como a construção civil trabalha com produtos com ciclos longos, os desvios em construção civil não podem ser corrigidos, mas sim compensados.
} 
de detalhamento deve ser aumentado ou diminuído, mas os objetivos globais devem ser mantidos e desdobrados nos diversos níveis (estratégico, tático e operacional), conforme a necessidade de operação da informação.

Nesta pesquisa, será estudada a dimensão horizontal do processo de planejamento no nível operacional, e a análise da dimensão vertical na aderência do planejamento operacional aos níveis hierárquicos superiores (tático e estratégico).

\subsubsection{Estrutura organizacional orientada por processos}

Halpin e Woodhead (2004) colocam que "um dos primeiros problemas com o qual se depara um empreendedor (...) é o de decidir como organizar da melhor forma possível a empresa para alcançar as metas de lucratividade e controle, assim como desempenhar as funções técnicas". Os autores também mencionam que existem duas estruturas formais em uma organização: uma estrutura organizacional relativa à organização legal da organização e a outra, que enfoca a organização gerencial. "A estrutura gerencial estabelece as áreas e os níveis de responsabilidade em alcançar os objetivos da companhia e é o mapa rodoviário que determina como os membros da empresa se comunicam entre si em questões de interesse comum”, de acordo com esses autores.

Segundo Vasconcellos e Hemsley (1997), "a estrutura de uma organização pode ser definida como o resultado de um processo através do qual a autoridade é distribuída, as atividades desde os níveis mais baixos até a Alta Administração são especificadas e um sistema de comunicação é delineado permitindo que as pessoas realizem as atividades e exerçam a autoridade que lhes compete para o atingimento dos objetivos organizacionais”. Esta estrutura deve ser delineada a partir de um conjunto de aspectos, que são: definição das atividades que são desenvolvidas na organização; escolha dos critérios de departamentalização (por função, por processo, por projeto, por critérios geográficos, etc); definição quanto à centralização ou descentralização das áreas de apoio, como tecnologia de informação, jurídico, etc.; localização de assessorias; decisão quanto à amplitude de controle e número de níveis hierárquicos; definição do nível de descentralização de autoridade; sistema de comunicação que será adotado; e definição do grau de formalização requerido (Figura 2.5). 


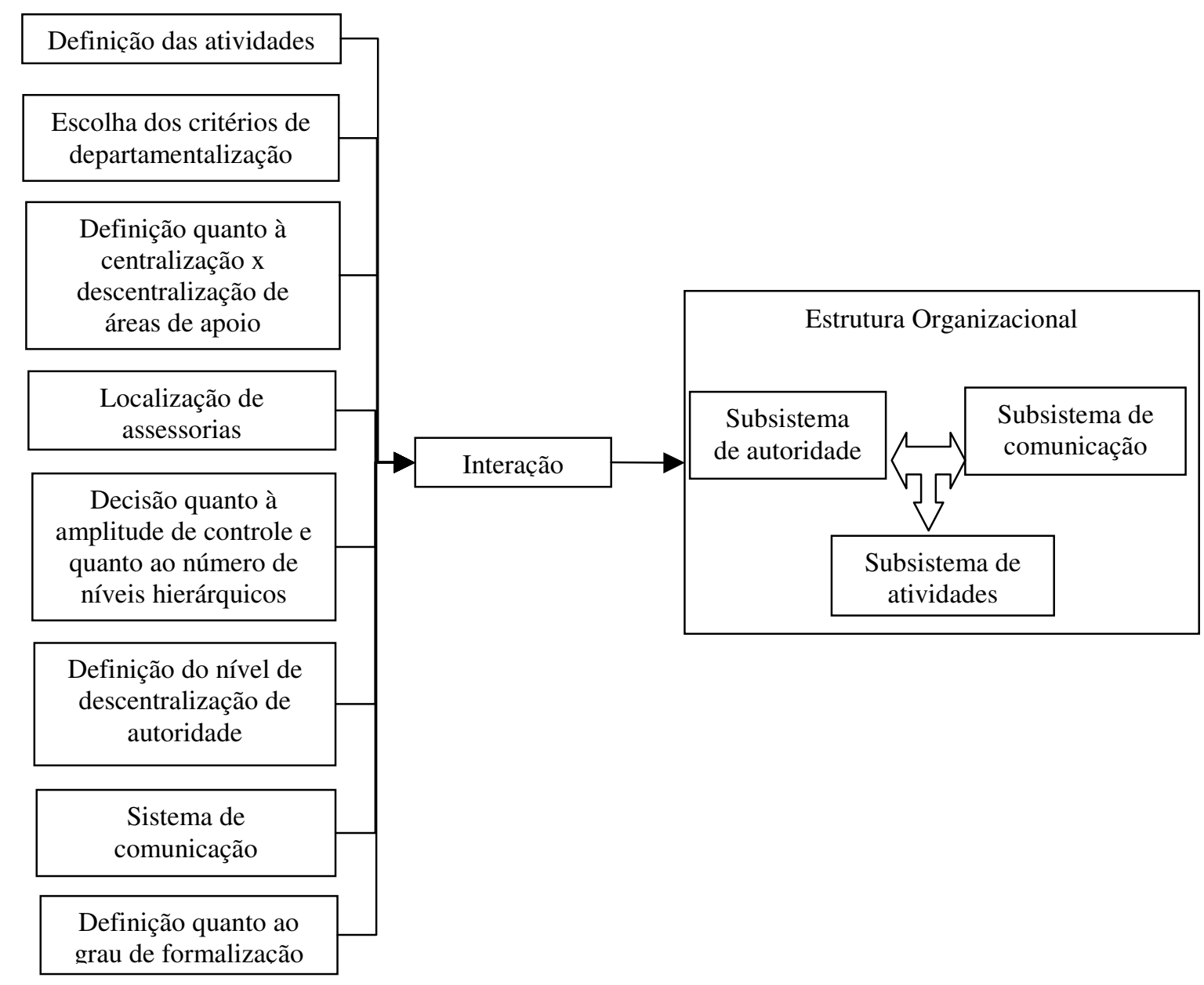

Figura 2.5 - Aspectos a serem considerados na formação de uma estrutura organizacional (adaptado de Vasconcellos e Hemsley (1997))

Um dos aspectos mencionados foi a escolha dos critérios de departamentalização. Por departamentalização pode se entender, por Vasconcellos e Hemsley (1997), que "é o processo de agrupar indivíduos em unidades para que possam ser administrados". Essas unidades são então organizadas em unidades maiores, até o nível mais alto da empresa. Neste processo de agrupar indivíduos, segundo os mesmos autores, são utilizadas características comuns ao trabalho desenvolvido, que envolvem critérios que podem ser, entre os mais utilizados, funcionais, geográfico, por processos, por clientes e por produtos.

Vasconcellos e Hemsley (1997) explicam que a "departamentalização funcional tem como critério básico a área do conhecimento necessário para a realização da atividade”. Ou seja, os indivíduos que possuem e atuam com os mesmos conhecimentos são agrupados em unidades de trabalho. Estes conhecimentos, nas organizações, como mencionado pelos autores, são 
freqüentemente as principais áreas gerenciais como finanças, marketing, recursos humanos, ou as funções gerenciais de planejamento, controle e estruturação.

Os autores ainda colocam que a especialização e a melhor utilização dos recursos, tanto humanos quanto materiais, são as grandes vantagens da departamentalização pelo critério funcional.

Lima Jr. (1978), já na década de 70, defendia a organização da empresa pelo critério funcional. De acordo com o autor, este tipo de organização facilita a determinação das responsabilidades e das autoridades, que são inerentes a cada função.

A departamentalização geográfica, de acordo com Vasconcellos e Hemsley (1997), pode ser utilizada em organizações que possuem seus escritórios e fábricas localizados em diversas cidades e países. Cada unidade localizada em uma cidade ou país, é considerada um departamento, dentro da estrutura da organização, sendo fundamental que haja uma massa crítica de atividades em cada área para justificar esta forma de departamentalização. Este tipo de estrutura permite, dentro de cada departamento, conhecer melhor os problemas de cada área, visto que estão todos agrupados em uma mesma unidade e, portanto, atender melhor às suas necessidades.

Em organizações que trabalham com diferentes perfis de cliente, a departamentalização pode ser feita considerando cada tipo de cliente. Neste caso, segundo Vasconcellos e Hemsley (1997) "são agrupadas, em uma mesma unidade, pessoas que lidam com o mesmo tipo de cliente". Semelhante a este tipo de departamentalização, é a estruturação por produtos ou por serviços, quando estes são muito diversificados.

A departamentalização por processos, conforme também citada por Vasconcellos e Hemsley (1997), é bastante utilizada no setor de produção, e visa agrupar atividades da organização conforme as fases de produção. Por exemplo, no setor da indústria, a organização pode ser estruturada pelos seus processos de produção como fundição, usinagem, montagem, pintura, embalagem, etc.

Dentre os tipos de estrutura organizacional tem-se a chamada estrutura tradicional, que possui, segundo Vasconcellos e Hemsley (1997) as seguintes características: alto nível de formalização; unidade de comando; especialização elevada; comunicação vertical; e utilização das formas tradicionais de departamentalização. Ainda segundo os autores, este tipo de estrutura é favorável a ambientes estáveis e organizações com atividades repetitivas. 
Os mesmos autores também mencionam que "com o aumento da complexidade do ambiente observado nas últimas décadas, tornou-se necessária, em certos setores, a existência de organizações inovativas que pudessem responder de forma eficaz a essas mudanças". Estas estruturas inovadoras possuem as seguintes características, inversas às da estrutura tradicional: baixo nível de formalização; utilização de formas avançadas de departamentalização; multiplicidade de comando; diversificação elevada; comunicação horizontal e diagonal. Uma das principais estruturas chamadas inovadoras são as estruturas matriciais.

A estrutura matricial, segundo Vasconcellos e Hemsley (1997), é uma "solução devido à inadequação da estrutura [tradicional] funcional para as atividades integradas, isto é, aquelas que para serem realizadas exigem interação entre as áreas funcionais”. Os autores também mencionam que a "matriz é uma forma de manter as unidades funcionais criando relações horizontais entre elas".

A matriz é o resultado da estruturação da organização seguindo critérios de mais de um tipo de estrutura, sobre os mesmos indivíduos, simultaneamente. Ou seja, a estrutura matricial é uma combinação de estruturas. Portanto, "há uma grande variedade de estruturas matriciais dependendo da dosagem com que cada tipo de estrutura participa nessa combinação", conforme Vasconcellos e Hemsley (1997).

Em análise comparativa dos dois tipos de estrutura, a tradicional e a matricial, tem-se a principal diferença no fator comunicação. Segundo Vasconcellos e Hemsley (1997), um dos pontos fracos das estruturas tradicionais é a comunicação, principalmente quando é necessária a integração dos diversos departamentos. Nestes tipos de estrutura a comunicação é realizada através das linhas de autoridade, ou seja, predomina a comunicação vertical. Já a estrutura matricial possibilita uma comunicação direta, a chamada comunicação horizontal entre indivíduos do mesmo nível hierárquico, agilizando a organização. No entanto, de acordo com os mesmos autores, "este vínculo direto pode causar problemas de coordenação e desgaste da autoridade dos chefes se certos cuidados não são tomados”. Os autores indicam que deve existir a identificação dos procedimentos de comunicação que devem ser adotados na organização, para cada tipo de estrutura, e que os indivíduos devem ser treinados, com a finalidade de evitar que a estrutura adotada seja levada ao fracasso por problemas de comunicação. 
Outro fator de diferenciação dos dois tipos de estrutura é a autoridade. Em estruturas tradicionais, segundo Vasconcellos e Hemsley (1997), as decisões estão centralizadas no topo da hierarquia, causando, muitas vezes, sobrecarga da diretoria da empresa, demora nas decisões, e decisões desvinculadas da realidade. Já as estruturas matriciais proporcionam a distribuição das decisões nos níveis hierárquicos, mas isso também pode acarretar problemas com a descentralização excessiva das decisões, dificuldade de coordenação e controle.

Um dos tipos de estruturas organizacionais consideradas como inovadoras e com origem na estrutura matricial é a estrutura organizada por processos. Harrington (1993) e Salerno (1998) explicam que a organização por processos tem suas raízes nas estruturas matriciais, mas possui características específicas. Para os autores, enquanto na estrutura matricial são mantidas as unidades funcionais e ao mesmo tempo são criadas unidades de projetos, ou seja, há uma nova estruturação da empresa principalmente quanto às responsabilidades e autoridades, na estrutura por processos a principal característica é a coordenação e gestão com base na estratégia de negócios da empresa, sem necessariamente alteração da forma como a empresa organiza suas unidades. Ou seja, a estrutura por processos pode ser entendida como uma forma de gestão.

Davenport (1994) e Salerno (1998) também enfatizam que a gestão por processos não exige uma nova organização das unidades da empresa, com a extinção da estrutura departamental. Essa forma de estruturação da empresa significa uma alternativa à forma de gestão e coordenação das atividades desenvolvidas nas diversas unidades da empresa, que pode estar estruturada por departamentos seguindo critérios de funcionalidade.

Este tipo de configuração organizacional começou a ser adotado nas empresas principalmente com o advento da Qualidade Total, e implantação de sistemas de gestão da qualidade com base na série de normas NBR ISO 9001, na sua versão 2000 (ABNT, 2000), que introduziu os conceitos de cadeia de processos intra e inter-organizacional e a cadeia de valores com foco no cliente. Outras correntes de estudo das organizações, como a Reengenharia de Processos, também trabalham e introduziram os conceitos de gestão por processos nas empresas.

Contador (1997) justifica a adoção desta forma de gestão mais do que de estrutura organizacional enfatizando que "o cliente vê o fornecedor como um conjunto de processos interligados, que tem como finalidade a produção de um bem ou serviço que ele necessita, então, por que as empresas são organizadas segundo um modelo de departamentalização?" 
A organização da empresa voltada aos processos com foco no cliente surgiu, segundo Harrington (1993) e também comentado por Ohnuma (2003), devido: a) aos avanços da tecnologia da informação, que concede um maior poder às pessoas para participar e coordenar o processo de trabalho em diferentes momentos; b) à transição para uma economia de serviços, já que a necessidade de entendimento e satisfação das exigências dos clientes aumentou sensivelmente; e c) à introdução de iniciativas da Qualidade Total, a fim de integrar pessoas, processos e tecnologia sempre com foco no cliente.

Tanto Contador (1997) quanto Salerno (1998) traçam um comparativo entre a estruturação da empresa por departamentos e a organização por processos. Os autores colocam que a empresa estruturada por departamentos geralmente possui problemas de cooperação entre as unidades, coordenação e integração. Já em empresas que se organizam por processos, existe foco no negócio, visto que os processos são orientados pela estratégia da empresa, há agilidade nas operações e conseqüente redução de custo, pois atividades que não agregam valor são eliminadas ou reduzidas, e é criada uma responsabilidade mútua e coletiva entre os diversos envolvidos nos processos, pois todos são responsáveis pelo produto/serviço final (Figura 2.6).
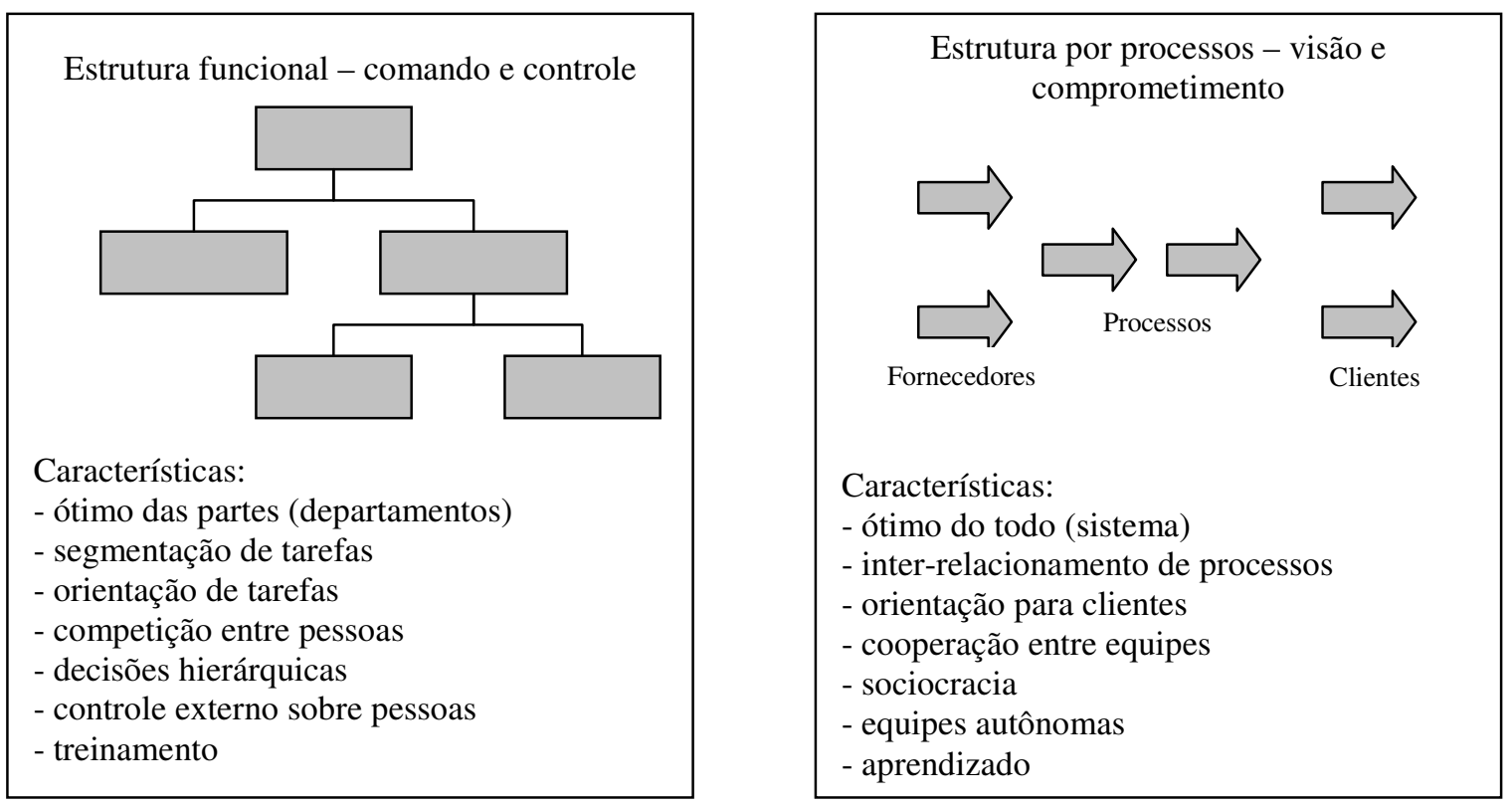

Figura 2.6 - Estrutura tradicional funcional departamentalizada e estrutura gerenciada por processos (adaptado de Contador (1997)) 
Cabe mencionar a observação feita por Vasconcellos e Hemsley (1997) quanto à estrutura "real" da organização. A estrutura "real" de uma empresa é formada pela estrutura formal e pela estrutura informal atuando simultaneamente. Segundo os autores, "a estrutura formal é aquela explicitada em manuais de organização que descrevem os níveis de autoridade e responsabilidades dos vários departamentos e seções”, ou seja, é a representação gráfica e registrada da estrutura, apresentada principalmente pelo organograma. Já a estrutura informal é baseada na improvisação e interação pessoal dos indivíduos dentro de uma organização. Os autores ainda colocam que a composição da estrutura real em termos de formal-informal pode variar bastante dentro de uma mesma organização, em momentos e situações diferentes.

A formalização das atividades de uma empresa é necessária, principalmente na gestão dos recursos, materiais, pessoas e informação. Dentro desta necessidade, a implementação de sistemas de gestão da qualidade, que como já mencionado tem foco na organização e gestão por processos, tem contribuído bastante. As empresas que implantam sistemas de gestão da qualidade precisam identificar seus processos, organizá-los em fluxo, definir procedimentos para executá-los e controlá-los, e definir canais de comunicação entre os processos e clientes internos e externos.

Com o foco no sistema de planejamento, segundo Assumpção (1996), a estrutura organizacional das empresas define como o planejamento é estabelecido e implementado nos diversos níveis hierárquicos. De acordo com o autor, “os sistemas de decisões (...), rebatidos sobre a estrutura organizacional da empresa, permitem identificar as funções para as quais devem ser geradas as informações e estruturados os sistemas de planejamento". Portanto, a forma como a empresa se organiza é fundamental no estabelecimento do sistema de planejamento, bem como na inserção e gestão do processo de planejamento no fluxo de processos da empresa.

O autor ainda reforça que "a compreensão destas estruturas de organização, com o entendimento do sistema de decisões que delas decorre é importante para caracterizar o sistema de planejamento operacional e os modelos que por ele são utilizados”.

Neste trabalho será considerada a empresa como constituída por uma cadeia estruturada por processos, ou seja, as atividades serão consideradas em agrupamentos necessários para o desenvolvimento de uma atividade final. Para tanto, serão consideradas as atividades relacionadas à gestão do processo de planejamento, mesmo quando desenvolvidas e sob a responsabilidade de diversos departamentos da empresa construtora. 


\subsubsection{Gestão por processos}

Os modelos de gestão das organizações são alterados ao longo dos anos devido, principalmente, às mudanças das necessidades competitivas e das exigências do mercado e da sociedade em geral, de acordo com Fabrício (2002). Com isso, a introdução de novas filosofias de gestão dos processos das organizações tem ligação estreita com as tendências e desafios competitivos do setor.

Com base nesta premissa, Fabrício (2002) menciona que "as recentes mudanças econômicas e culturais, atreladas em parte ao processo de globalização, influenciam significativamente as transformações internas do setor e o engajamento das empresas de construção na modernização de seus produtos e processos".

A modernização dos produtos e processos da empresa construtora é provocada pela concorrência no setor que exige, para a sobrevivência da empresa, a redução dos custos de produção e administrativos vinculada a um aumento do atendimento às exigências dos clientes. Segundo Farah (1992), a estratégia para redução de custos se dá através de dois mecanismos: "o primeiro consiste na utilização de insumos baratos e de baixa qualidade e na precarização das relações trabalhistas. O segundo mecanismo é a busca de aumento da produtividade e a ampliação da qualidade, como forma de baixar os custos de produção e melhorar a competitividade da empresa no mercado". O que se tem observado no setor da construção imobiliária, é a aplicação do segundo mecanismo na redução dos custos, ou seja, a modernização dos produtos e processos da empresa construtora.

Como destacado por Farah (1992), "a escassez de recursos inviabilizava a mobilização pesada dos recursos demandados para uma mudança radical da base técnica e da tecnologia construtiva tradicional. Ganharam força as estratégias de modernização centradas nas mudanças tecnológicas incrementais, na racionalização da produção e na introdução de modelos de gestão mais eficientes".

Lima Jr. (1995) ainda coloca que a composição de preços dos empreendimentos, formada pela soma dos custos de produção acrescidos do lucro, que é fornecida pela empresa, é substituída por um patamar de preço estabelecido pela concorrência. Com isso, as empresas construtoras precisam necessariamente ser mais eficientes para poderem participar do mercado, conseguindo apresentar seus produtos dentro dos custos ditados pela concorrência, obtendo níveis de rentabilidade e risco aceitáveis. 
Como um dos movimentos de modernização de produtos e processos que ocorreram e vem ocorrendo, tem-se a adoção efetiva e crescente valorização dos sistemas de gestão da qualidade pelas empresas construtoras, como mencionado por Picchi (1993), Melhado (1994), Cardoso (1996) e Souza (1997).

As empresas construtoras começaram a se preocupar com modernização de produtos e processos e buscar novas filosofias de gestão na primeira metade dos anos noventa, com a empresa Encol $^{6}$ sendo uma das primeiras empresas construtoras a implantar um sistema de gestão da qualidade. A partir de então, já na segunda metade dos anos noventa, houve um forte crescimento e valorização da certificação dos sistemas de gestão da qualidade, inclusive com a criação de programas setoriais ${ }^{7}$ voltados para a construção civil.

Estes sistemas de gestão, conforme explicação de Fabrício (2002), “têm como 'mote' a padronização, o controle e a melhoria contínua dos processos da empresa, através da formalização e estabilização de procedimentos de contratação, compras, produção, treinamento, controles, ensaios, solução de problemas, etc".

Um dos dez princípios da Qualidade Total, segundo Souza et al. (1995), é a gerência de processos. Este princípio visa identificar os processos que ocorrem na empresa, e organizar estes processos como cadeias de relacionamento cliente-fornecedor, eliminando interferências de coordenação e promovendo a integração interdepartamental. Estas interferências de coordenação e interfaces entre processos são apontadas por Davenport (1994) como um dos principais problemas gerenciais.

Outro modelo de gestão que objetiva a modernização de produtos e processos é o do Lean Production, ou Produção Enxuta, criado na empresa japonesa Toyota e denominado originalmente como Toyota Procuction System (TPS), ou Sistema de Produção Toyota. Este modelo de gestão foi mundialmente difundido por Womack, Jones e Roos (1992), e propõe às empresas uma nova forma de gestão da produção, com agrupamento de todas as atividades (da alta gerência passando pelos operários de linha aos fornecedores) em cadeias enxutas de agregação de valores. Koskela (1992) ainda ressalta que esta filosofia está centrada na gestão do fluxo de processos, que é caracterizada pelas atividades de fluxo, de conversão ou de valor (processamento).

\footnotetext{
${ }^{6} \mathrm{O}$ estudo do sistema de gestão da qualidade da Encol é apresentado em Picchi (1993).

${ }^{7}$ Qualihab e PBQP-H, voltados principalmente para a construção habitacional.
} 
O modelo de Produção Enxuta propõe o mapeamento dos fluxos de processos da empresa, tanto administrativos quanto de produção, para promover a análise dos processos, eliminação de atividades que não agregam valor ao cliente, e padronização das atividades. Com isso é possível realizar a gestão dos processos da empresa e não a gestão de atividades departamentalizadas e sem integração. Com a mesma finalidade, nos sistemas de gestão da qualidade, são definidos os procedimentos gerenciais para organizar o fluxo de trabalho, definir responsabilidades e autoridades, e resolver interfaces de processos. O que se observa, em ambos os modelos de gestão por processos, é a importância do gerenciamento da informação, fundamental no controle dos processos principais.

A preocupação com o cliente tem se tornado cada vez mais marcante e fundamental para a sobrevivência da empresa no mercado. Por isso, modelos de gestão orientados pela definição e atendimento às necessidades do cliente são cada vez mais adotados pelas empresas construtoras. Contador (1997) ressalta que a gestão por processos já é orientada aos clientes, já que a geração de um produto ou serviço é realizada pela cadeia de um ou mais processos interligados, que se relacionam reciprocamente como clientes e fornecedores.

Harrington (1993) identifica cinco tipos diferentes de clientes para um único processo:

a) os primários, que recebem diretamente as saídas do processo;

b) os secundários, que são considerados empresas fora dos limites do processo e que se situam em um ponto intermediário do processo principal, não possuindo relação direta com o resultado final;

c) os indiretos, que são clientes dentro da empresa, mas que não fazem parte internamente do processo, mas que são afetados se o processo gerar saídas erradas ou atrasadas;

d) os externos, que se situam fora da empresa e que recebem o produto ou serviço final;

e) os consumidores, que recebem indiretamente o produto quando existe um intermediário para realizar a sua entrega ou venda.

Com base nos conceitos apresentados pelos diversos autores, de gestão por processos e ambiente competitivo do mercado, as alternativas de reorganização das empresas com base em seus processos vem ao encontro das necessidades de mudanças. No entanto, estas mudanças devem ocorrer dentro da organização e, principalmente, na forma como os gestores da organização visualizam seus processos. A reorganização da empresa desvinculada da 
mudança de cultura dos gestores, que devem visualizar a empresa como processos e não como departamentos, pode não gerar os resultados esperados.

\subsection{CARACTERIZAÇÃO DO PROCESSO DE PLANEJAMENTO DA PRODUÇÃO}

Através da caracterização do fluxo de processos da empresa construtora, é analisada a inserção do processo de planejamento da produção neste fluxo, e são identificadas as diversas interfaces existentes.

Com base nestes aspectos identificados do processo de planejamento da produção, são analisadas a gestão deste processo, bem como as características da subcontratação do planejamento da produção. Por fim, são analisadas as competências do planejamento da produção e da gestão deste processo.

\subsubsection{Fluxo de processos}

Como já discutido nas seções anteriores, a gestão por processos visualiza a empresa como um encadeamento lógico de processos que são orientados pelo produto ou serviço que deve ser entregue ao cliente final. Este encadeamento lógico dos processos de uma empresa é o fluxo de processos (Figura 2.7).

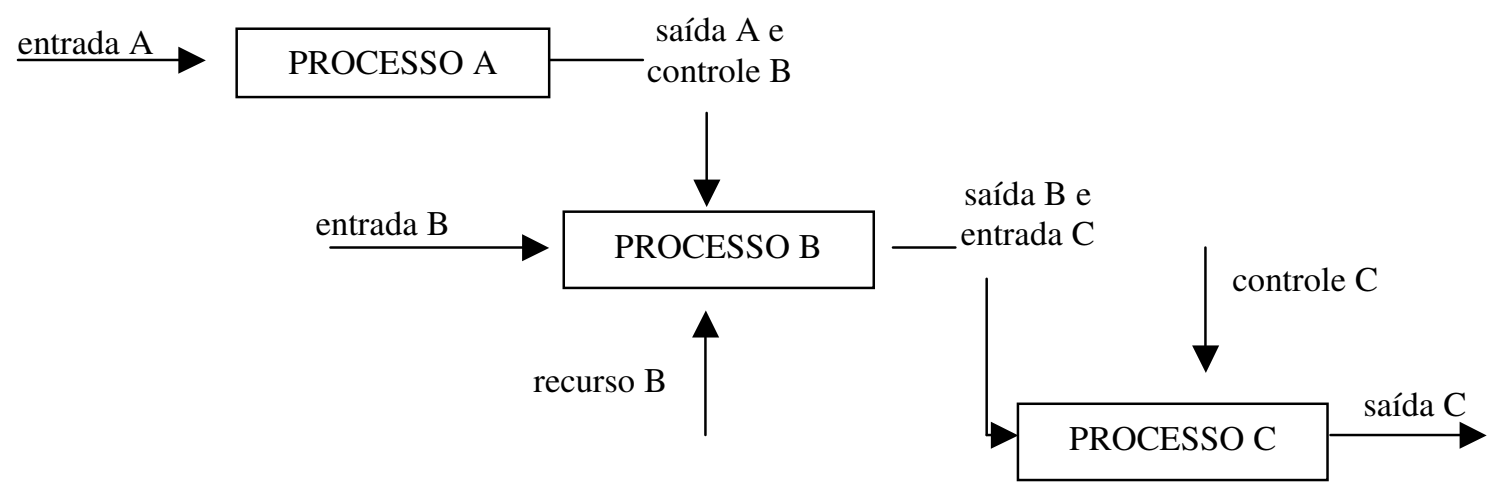

Figura 2.7 - Cadeia de processos (ABNT, 2000)

Antes de descrever o fluxo de processos da empresa construtora, é preciso entender a natureza do produto que é entregue ao cliente final, e para o qual é dirigido o fluxo de processos da empresa. 
Fabrício (2002) apresenta o produto da construção civil, o empreendimento, como único e singular. De acordo com o autor, "o edifício é um objeto complexo pela multiplicidade de técnicas, de agentes e de pontos de vistas envolvidos na sua concepção e realização, implicando a não existência de dois empreendimentos de construção idênticos". O autor ainda traça um paralelo à indústria de produção seriada, pois "os negócios e os empreendimentos gerados na construção são organizados segundo ciclos de produção relativamente únicos e não repetitivos que são vinculados a determinado local (terreno) onde se dará a construção e se estabelecerá o produto edifício", o que possui uma organização diferente da indústria de produção seriada que tem ciclos repetitivos, localizados em determinada fábrica e em uma linha de montagem pré-definida. Ou seja, segundo o mesmo autor, "os processo produtivos das empresas do setor são organizados segundo ciclos intermitentes em que a unidade de produção é o empreendimento".

Portanto, na construção civil, pelo fato de cada produto representar uma realidade distinta, com exigências funcionais, prazos e processos específicos, alguns autores, conforme menciona Amorim (1995), se referem à construção como uma indústria de protótipos, organizada para produção de produtos únicos e diferenciados.

Fabrício (2002) ainda comenta que, pela construção civil ser uma indústria de protótipos, os processos produtivos são organizados visando a unidade básica de atividade produtiva, ou seja, o empreendimento. “Assim, o processo de produção do setor de construção está centrado nos empreendimentos individuais para os quais convergem os materiais e componentes industrializados e os serviços subcontratados".

O ciclo de vida de um empreendimento de construção de edifício, segundo Fabrício (2002), compreende quatro fases principais: 1) montagem da operação; 2) projeto; 3) execução e entrega; 4) uso, operação e manutenção do edifício. As fases são desenvolvidas de forma hierárquica e fragmentada, e envolvem a participação de diversos agentes, comenta o autor. Entre os agentes, se destacam o empreendedor, que é responsável pela formação do produto, os projetistas, que concebem e formalizam o produto, o construtor, que fabrica o produto, e o usuário, que utiliza o produto e assume a manutenção.

Além destes agentes principais, têm-se os investidores e agentes financeiros, que participam do empreendimento com o capital, e os fornecedores de materiais, equipamentos, mão-deobra e serviços especializados, complementa Fabrício (2002). 
Cardoso (1996) apresenta a definição de processo de produção e sistema de produção de um empreendimento. Processo de produção, para o autor, compreende "o conjunto das etapas físicas, organizadas de forma coerente no tempo, que dizem respeito à construção de uma obra: essas etapas concentram-se sobre a execução, mas vão desde os estudos comerciais, até a utilização da obra, e são asseguradas por diferentes agentes”.

Já sistema de produção é definido como "o modo de articulação entre um sistema de operações físicas de produção (inserido em suas dimensões técnico-sociais) e um sistema de operações de gestão, de condução, controle e avaliação dos resultados (inserido em suas dimensões técnico-organizacionais)". Ou seja, são as operações necessárias para viabilizar a produção do empreendimento.

Ahuja (1994) também caracteriza o ciclo de vida de um empreendimento em quatro fases: concepção, desenvolvimento, execução, e conclusão. De acordo com o autor, é importante entender o conceito do ciclo de vida de um projeto porque expectativas dos clientes e das equipes de trabalho devem ser compatibilizadas com o que pode ser esperado durante uma fase em particular. Ou seja, deve estar definido objetivamente o que é executado em cada fase e é oferecido pela equipe do empreendimento, e o que pode ser solicitado pelo cliente.

A fase de concepção caracteriza o início da fase de planejamento, com a identificação da necessidade e a criação do conceito do empreendimento. Inicialmente, membros da equipe do empreendimento começam a estudar a viabilidade das várias alternativas. É também durante esta fase que os primeiros projetos e diagramas são produzidos. Conforme o escopo vai sendo definido, são usados orçamentos e cronogramas iniciais para análise da viabilidade do empreendimento.

$\mathrm{Na}$ fase de desenvolvimento, o plano é aprimorado com informações adicionais de engenharia. Diagramas são transformados em fluxos de processos, e estudos adicionais de engenharia e análises financeiras são elaborados para definir o orçamento, cronograma e fluxo de caixa mais apurados. $\mathrm{O}$ autor ainda ressalta que a definição do escopo não necessariamente é concluída nesta fase.

$\mathrm{Na}$ fase de execução, são dispensados mais esforços, pois os estudos de engenharia, suprimento, e construção são completados nesta fase. O autor também menciona que esta fase é executada com mais facilidade quando as duas primeiras fases, concepção e desenvolvimento, são mais analisadas. 
O procedimento final é a fase de conclusão, na qual o empreendimento é concluído. Nesta fase, as responsabilidades da posse são transferidas para o cliente, e este assume a manutenção do empreendimento.

Souza (2001) apresenta o fluxo de processos com as fases e atividades de um empreendimento (Figura 2.8). 


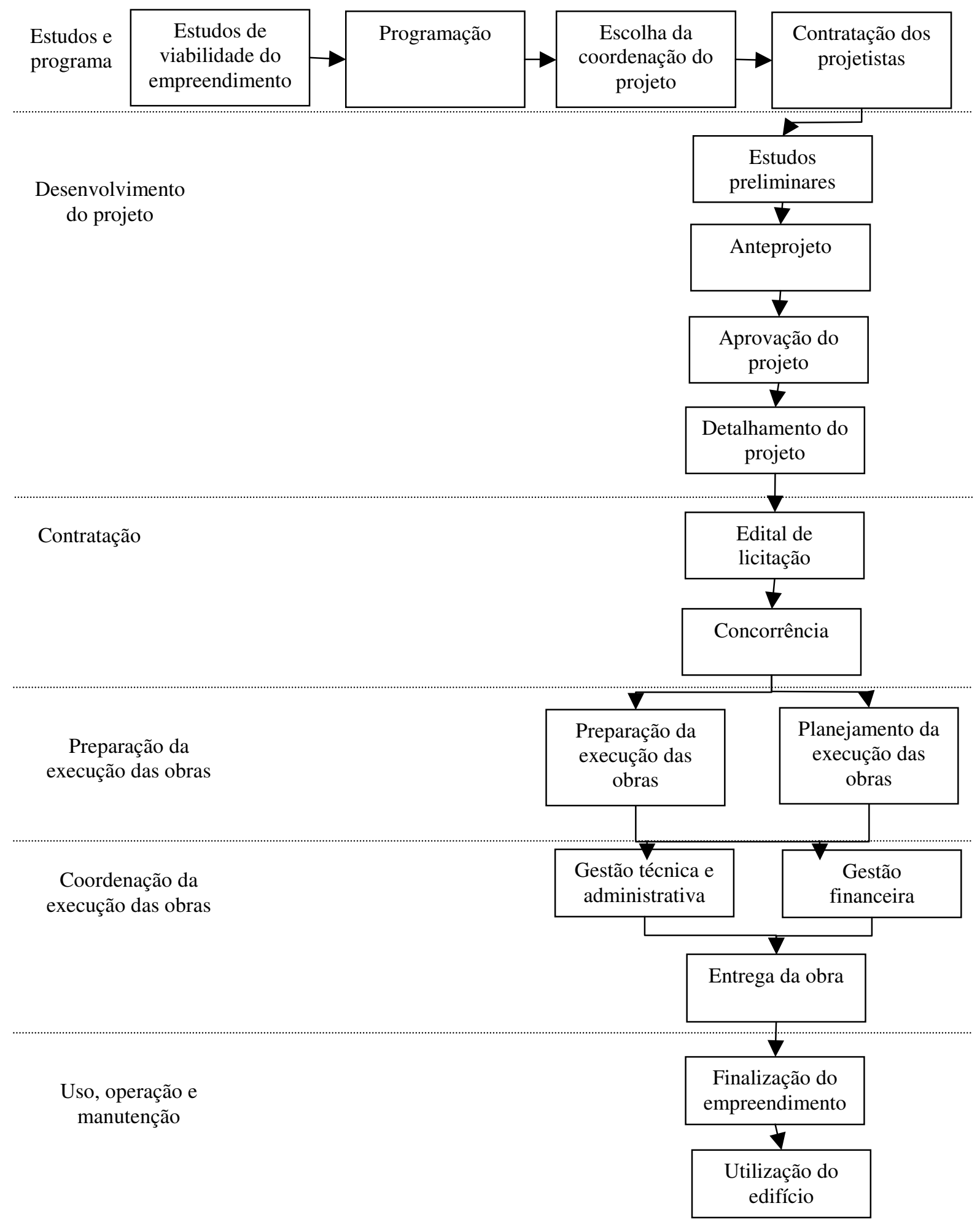

Figura 2.8 - Fases e atividades de um empreendimento (SOUZA, 2001)

Na primeira fase, denominada pela autora como estudos e programa, é realizada a montagem do empreendimento. Segundo Souza (2001), “a montagem do empreendimento é o passo 
inicial de uma operação de construção. Ela tem início com as primeiras reflexões com relação à obra e seu término, não apresentando uma fronteira precisa; ocorre aproximadamente no momento em que as empresas construtoras são escolhidas e o financiamento para a realização do empreendimento é estabelecido”. Esta fase é desenvolvida pela empresa incorporadora, empreendedor, e investidores.

Na segunda, desenvolvimento do projeto, a equipe de projetistas ocupa a função central. "Ela garante a proposta arquitetônica, técnica e econômica com relação ao programa estabelecido pelo empreendedor", segundo a autora. Esta fase pode se dar ainda pelo empreendedor, ou já repassada para a construtora.

A contratação das empresas construtoras caracteriza a terceira fase, e é onde se dá início a quarta fase. Na quarta fase, preparação da execução da obra, dá-se início à preparação propriamente dita, e as atividades de planejamento da execução das obras. Souza (2001) propõe uma metodologia para desenvolvimento e implementação da fase de Preparação da Execução da Obra, denominada PEO, nas empresas construtoras. Atualmente, no Brasil, como exposto pela autora, poucas empresas construtoras aplicam esta fase de forma estruturada e sistemática.

A coordenação da execução das obras, quinta fase, constitui a execução da obra e a empresa construtora é o principal agente.

Na sexta e última fase, recepção e gestão do empreendimento (uso, operação e manutenção), "é novamente o empreendedor o agente responsável em executar a tarefa de garantir a recepção do empreendimento, com ou sem pendências", explica Souza (2001).

O conceito de fluxo de processo bem como a ferramenta de análise de fluxo serão utilizados neste trabalho para a análise do processo de planejamento da produção e das interfaces deste processo. Por isso, é apresentada uma breve introdução sobre a ferramenta que será utilizada neste trabalho, a ferramenta gráfica de fluxograma.

Harrington (1993) apresenta o desenvolvimento do fluxograma pelas etapas de: a) identificação dos processos críticos e dos respectivos subprocessos; b) seleção dos responsáveis pelos processos; c) identificação das atividades envolvidas nos processos e subprocessos; d) definição dos limites de cada processo, ou seja, entradas, saídas e processos que formam as interfaces; e) traçado do fluxograma do processo, definindo as relações de 
interdependência entre atividades; f) estabelecimento dos pontos de controle de cada processo; e g) reavaliação dos limites de cada processo.

Através destas etapas, o processo é desenhado graficamente, bem como seu interrelacionamento no fluxo de processos da organização (Figura 2.9).

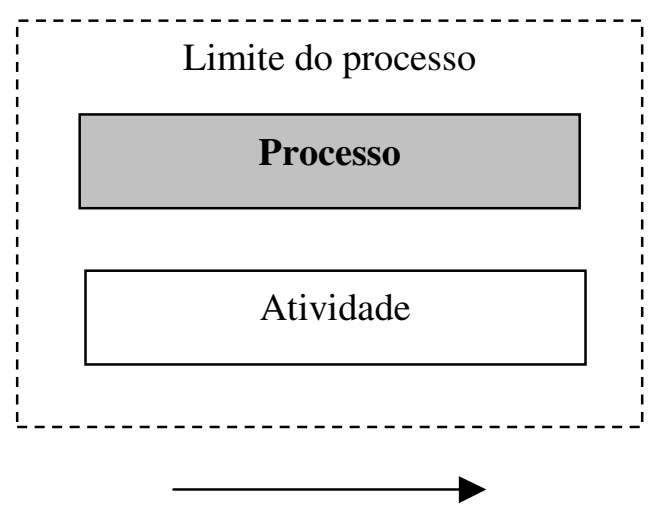

Fluxo de informação

Figura 2.9 - Simbologia adotada para o fluxo de processos

\subsubsection{O planejamento da produção como processo}

Como já definido em seção anterior, neste trabalho será tratado o processo de planejamento no nível hierárquico operacional, na sua dimensão horizontal, ou seja, o processo de planejamento da produção, que envolve a programação e controle no nível operacional, no longo, médio e curto prazo. No entanto, não será perdida, na análise, a visão de conjunto do planejamento nos demais níveis hierárquicos.

O planejamento da produção pode ser considerado um processo, segundo Varalla (2003), pois envolve a execução de muitas atividades inter-relacionadas e interdependentes, como: a) a definição dos envolvidos e as suas responsabilidades; b) a definição e coleta de informações, como projetos das diferentes disciplinas envolvidas, especificações técnicas, orçamento; c) estabelecimento de prazos para realização do planejamento; d) definição do grau de detalhe que se deseja atingir; e e) definição dos recursos necessários para realização do planejamento, como técnicas e ferramentas.

O processo de planejamento da produção pode ser caracterizado por suas entradas, recursos, operação, controle e saída, como ilustrado na figura 2.10 . 


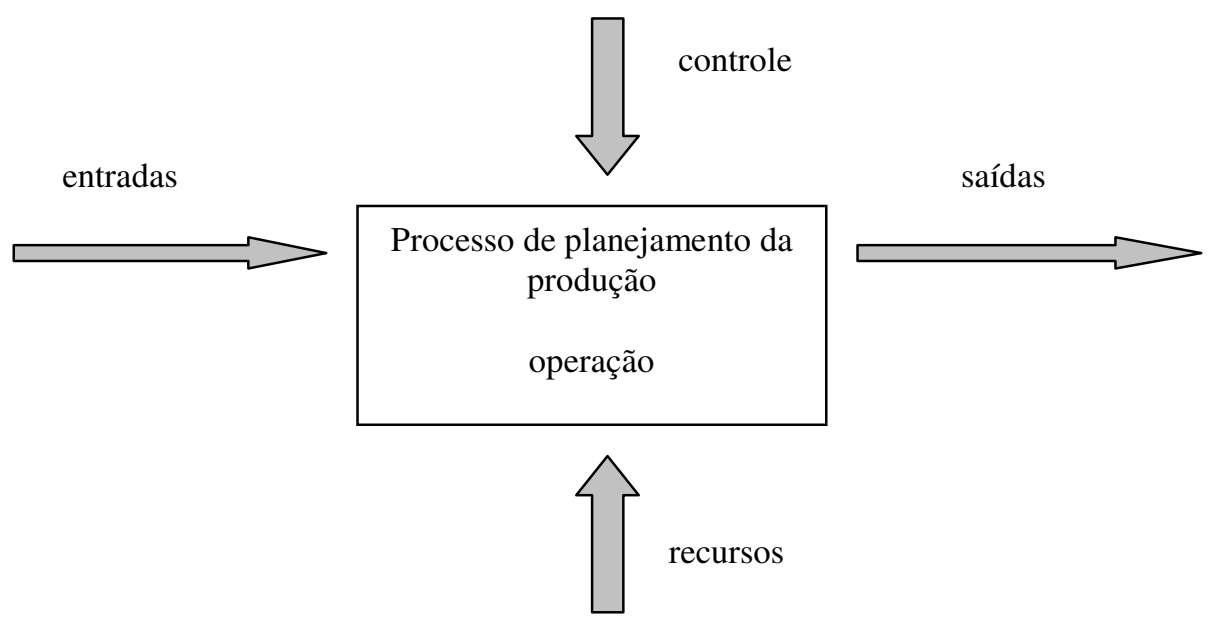

Figura 2.10 - Processo de planejamento da produção

\section{1) Entradas do processo}

As entradas do processo de planejamento são informações resultantes do processo comercial e do processo de projetos, que correspondem a: dados e conceitos iniciais do empreendimento caracterizado pelo programa do empreendimento ${ }^{8}$, informações de custos e prazo decorrentes de análises financeiras, métodos construtivos já discutidos para a viabilização do empreendimento, projetos já desenvolvidos, definição de equipe administrativa alocada e tipo de contratações que serão realizadas e condições de canteiro de obras.

Após a execução da programação da produção, e sua efetiva implementação, a obra também fornece dados de entrada para o processo de planejamento da produção retroagir, que são, segundo Goldman (2004):

a) informações sobre a utilização dos insumos, como custos, locais de aplicação, estoques. Estes dados possibilitam o sistema de controle sobre os insumos e apropriação por serviços;

b) previsão de despesas, como programa de execução, para que exista aderência do fluxo de caixa ao cronograma físico-financeiro;

c) controle de produtividade das equipes, para avaliação do andamento físico-financeiro da obra, e retroalimentação de banco da dados para futuras obras; e

\footnotetext{
${ }^{8}$ Fabrício (2002) descreve a composição deste programa do empreendimento e como deve ser elaborado e compartilhado entre os agentes do empreendimento.
} 
d) verificação de materiais e serviços executados, sendo possível a análise da programação executada.

Através das informações recebidas da obra é que o processo de planejamento da produção implementa o sistema de controle. Com isso, o planejamento assessora a execução da obra e também controla, segundo Goldman (2004).

\section{2) Recursos}

Os recursos utilizados no processo de planejamento da produção são principalmente as pessoas, que desenvolvem as ferramentas e gerenciam o processo, e os recursos da tecnologia da informação, que fornecem softwares de desenvolvimento de ferramentas de programação e controle, e bancos de dados gerenciais e de cooperação entre os agentes.

\section{3) Operação}

De acordo com Goldman (2004), "o planejamento constitui hoje um dos principais fatores para o sucesso de qualquer empreendimento. No tocante à construção predial, faz-se necessário um sistema que possa canalizar informações e conhecimentos dos mais diversos setores e, posteriormente, direcioná-los de tal forma que todas essas informações e conhecimentos sejam utilizados para a construção".

As responsabilidades do processo de planejamento, em uma empresa de construção, segundo Goldman (2004), são: a) estudo de viabilidade técnico-econômica do empreendimento; b) planejamento técnico-econômico das obras; c) controle técnico-econômico das obras em andamento; e d) obtenção e análise dos resultados técnico-econômicos do empreendimento.

Dentro destas responsabilidades do processo como um todo, Assumpção (1988) apresenta as principais atividades do processo de planejamento da obra, que são: a) coleta e análise das informações sobre a obra, que inclui análise dos projetos e especificações técnicas, conhecimento dos condicionantes físicos do local, conhecimento da disponibilidade e dos custos dos recursos disponíveis na região e conhecimento da trajetória ou desenvolvimento da obra; b) identificação das etapas, atividades e serviços necessários para a execução da obra; c) definição dos processos de trabalho (logística de suprimento e de canteiro); d) levantamento 
de quantidades de serviços; e) alocação de recursos (materiais, mão-de-obra e equipamentos) com estimativa das durações para cada serviço; e f) definição da seqüência tecnológica.

Souza (2001) também menciona quais ações devem ser priorizadas no processo de planejamento e organização da fase de execução das obras. Estas ações compreendem:

1) a definição da organização do canteiro de obras e de áreas de vivência (estudo da logística);

2) a conclusão dos projetos para produção dos principais serviços. Com isso, cada agente deve apresentar suas necessidades com relação ao acesso ao canteiro de obras, estocagem dos materiais e componentes, posicionamento dos equipamentos;

3) a elaboração da programação de atividades, e análise dos envolvidos, garantindo assim o comprometimento de todos. Nesta programação também devem ser contemplados os prazos para contratação dos serviços que serão terceirizados, e materiais e equipamentos;

4) a análise das equipes que podem influenciar a organização e o andamento dos trabalhos no canteiro de obras;

5) a análise dos caminhos críticos, definindo-se soluções para as interfaces identificadas que podem vir a complicar o planejamento definido;

6) a definição de responsabilidades como pela limpeza e pela remoção de entulho, que são atividades não identificadas na programação mas que podem afetar o andamento da obra; e

7) a definição de uma agenda de reuniões para análise critica do processo de planejamento.

A autora também ressalta que "devem ser levados em consideração não apenas o aspecto físico e o prazo para a execução dos serviços, mas um conjunto de fatores que contribuem para a sua realização. Por exemplo, devem ser considerados no planejamento: a antecedência com que o projeto deve chegar ao canteiro de obras; quais os itens que serão controlados, a solicitação de amostras, a demanda de materiais, componentes e equipamentos, a necessidade da conclusão de um serviço para o início do outro".

$\mathrm{Na}$ manipulação dos dados de entrada são utilizados modelos que simulam cenários projetados. De acordo com Assumpção (1996), “os modelos para planejamento operacional quando formulados para simular estratégias de produção, devem representar as variáveis e atividades deste processo, mostrando sequiências e trajetória para execução da obra, e os principais insumos e custos envolvidos na sua produção". O autor também comenta que "os 
planos são voltados para atender aos objetivos do empreendimento e da empresa", ou seja, o modelo deve simular as operações de produção sem perder de vista a estratégia da empresa.

Segundo Halpin e Riggs (1992), um modelo é a representação das situações do mundo real e geralmente fornece uma referência na qual uma situação pode ser investigada e analisada. Os autores complementam afirmando que modelos possuem dados sobre uma situação que, quando interpretada de acordo com certas regras ou convenções, fornece informações sobre os pontos importantes para as decisões de processo. Para tanto, são utilizados modelos matemáticos na identificação dos problemas.

O modelo trabalha com a organização das operações de construção. Segundo Halpin e Woodhead (2004), "as operações de construção podem ser consideradas e definidas em termos de conjuntos específicos de tarefas de trabalho, em que a tarefa de trabalho é um componente básico ou elementar de trabalho". Ou seja, a tarefa de trabalho é uma atividade do processo de produção que, designada a uma equipe, demonstra o que está envolvido e o que é necessário para a execução do trabalho. O modelo ordena logicamente de acordo com a tecnologia do processo de construção e do plano de trabalho. O plano de trabalho, de acordo com os autores, "prescreve a ordem na qual os meios serão disponibilizados para que a operação da construção execute as diversas tarefas de trabalho".

Os autores ainda complementam que "uma descrição completa de uma operação de construção requer a definição das tarefas básicas da construção e a forma como as entidades ou recursos disponíveis executam as tarefas de trabalho. (...) As relações seqüenciais, relativas e lógicas entre as várias tarefas de trabalho, como definidas pelos diferentes fluxos de recursos, caracterizam o plano, ou estrutura estática, da operação e tecnologia da construção. O trabalho real da operação pode então ser descrito pela locação e monitoramento, de tempos em tempos, das várias entidades ou recursos, na forma dinâmica da passagem deles pela estrutura estática da operação". Com isso, tem-se a interação da programação e do controle.

Segundo Cleland (1988), os requisitos básicos de uma programação são: a) deve ser compreendida; b) deve identificar os tempos de duração dos pacotes de trabalho; c) deve possibilitar a atualização e modificação quando necessário; e) deve fornecer bases para alocação, monitoramento e avaliação do uso dos recursos; f) deve apresentar estimativa de prazos exeqüíveis; e g) deve ser compatível com outros modelos de planejamento organizacionais. 
Assumpção (1996) comenta que os modelos para planejamento da produção devem ser mais detalhados em níveis inferiores da hierarquia do planejamento operacional. Como definido em seção anterior, o planejamento operacional também apresenta hierarquias que são a elaboração de modelos que trabalham com pacotes de trabalho mais macros no início do empreendimento, e o detalhamento destes pacotes conforme o andamento da construção, ou seja, o longo, médio e curto prazo. Conforme explica o autor, o modelo deve representar "o ato de produzir", por isso "os programas devem contemplar o dimensionamento de insumos para produção e os controles são estruturados para operar com o registro das informações no nível da sua ocorrência (consumo de materiais por serviço, produtividades por serviço, registro de notas fiscais, controle de empreiteiros, e outros, decorrentes das atividades de rotina da obra)".

Fachini (2005) também comenta que, no médio e curto prazo, deve-se analisar pequenos trechos do modelo de planejamento de longo prazo, definindo, assim, períodos de análise menores do que a duração da obra como um todo. Neste menor período, que pode chegar a ser o dia de trabalho ou até mesmo horas - variando conforme a necessidade ou complexidade da obra - os pacotes de trabalho devem ser divididos em tarefas e atividades.

$\mathrm{Na}$ formação de modelos operacionais na construção civil, algumas das técnicas de programação utilizadas são apresentadas:

\section{1) Rede de precedência}

Considerando que a programação consiste na divisão da construção em elementos que são apropriados para o controle do tempo, vem sendo adotado desde o início do século XX, a técnica de planejamento do tempo conhecida como gráfico de Gantt, criada no ambiente da indústria e adaptada e implementada no ambiente da construção. (HALPIN e WOODHEAD, 2004)

De acordo com Halpin e Woodhead (2004), “o conceito básico de modelagem do gráfico de barras é a representação de um item de trabalho ou atividade de um projeto como uma barra em escala de tempo cujo comprimento representa a duração prevista para a atividade”. Em uma representação geral do empreendimento, "o posicionamento relativo das atividades de trabalho do projeto indica o cronograma planejado e a seqüência do trabalho". 
A descrição de um empreendimento como uma rede de atividades pode ser elaborada pela abordagem do caminho crítico, ou CPM (Critical Path Method). Nesta abordagem, uma rede consiste em nós e conexões representando eventos ou atividades, ou a sequência lógica que relaciona as atividades entre si. (HALPIN e WOODHEAD, 2004)

Os modelos obtidos pela aplicação da técnica do CPM são determinísticos e fornecem apenas uma data de início e término das atividades e do modelo como um todo, pois qualquer variação na duração das atividades é considerada pequena ou insignificante. Uma evolução do CPM é a técnica PERT (Program Evaluation and Review Technique), que resulta em modelos probabilísticos, fornecendo expectativas de duração. O método do PERT fornece a variação das atividades, calculando a expectativa de duração com uma medida do risco da duração das atividades e do conjunto. (HALPIN e RIGGS, 1992)

Segundo Halpin e Riggs (1992), apesar da grande aceitação do CPM e PERT, os atrasos nos cronogramas continuam ser o principal problema. Um razão possível é que redes calculadas com CPM e PERT $^{9}$ não fornecem informação adequada considerando o potencial de atraso do cronograma.

Halpin e Woodhead (2004) criticam a rede de precedência por não refletir de maneira imediata "a taxa de produção ou a velocidade com que estão sendo processadas as seções ou unidades em projetos lineares". Para tanto, os autores explicam que a técnica de linha de balanço pode fornecer estas informações.

A análise de uma rede de precedência, de acordo com Halpin e Woodhead (2004), permite: identificar o caminho crítico, ou seja, a seqüência de atividades que possui a maior duração do modelo, e conseqüentemente, impõe a duração mínima da construção; calcular a data mínima de início de cada atividade; calcular a data máxima de cada atividade; e calcular a folga, ou tempo disponível para atraso de cada atividade.

\footnotetext{
${ }^{9}$ Apesar do PERT considerar a probabilidade nos cálculos, o PERT geralmente subestima a duração do projeto, quando todos as sequiências convergem em um nó. O cálculo do PERT dá a expectativa de término mais cedo deste nó como a somatória de tempos no caminho mais longo que chega no nó. No entanto, desde que as durações das atividades são faixas variáveis de duração, é possível que outra seqüência convergente neste nó possa vir a ter uma duração mais longa. (HALPIN e RIGGS, 1992)
} 


\section{2) Diagrama tempo-espaço ou Linhas de Balanço (LOB - Line of Balance)}

Diagrama tempo-espaço ou linha de balanço "relacionam unidades de produção (ou seja, quantidades ou distancias) no eixo ' $y$ ' (vertical, ordenada) com o tempo desenhado no eixo ' $\mathrm{x}$ ' (horizontal, abscissa). (...) A tangente à curva, portanto, representa o número de unidades produzidas em um dado intervalo de tempo. Isso é a taxa de produção". (HALPIN e WOODHEAD, 2004)

Esta técnica permite a coordenação das diversas atividades de forma a evitar intersecções nas curvas de produção. Com isso, os recursos são balanceados de modo a resultarem em uma taxa de produção, que se pretende ser a mesma em todas as operações de construção.

Segundo Halpin e Riggs (1992), em projetos caracterizados pela repetição das atividades, estas podem ser sincronizadas na duração e produtividade de modo que a utilização dos recursos possa ser racionalizada. No entanto, atrasos no desenvolvimento das atividades causam instabilidade na seqüência, mesmo nas situações balanceadas, com conseqüente perda da produtividade e problemas de gerenciamento da cadeia.

Um ponto negativo desta técnica, segundo Assumpção (1996), é a dificuldade na análise dos recursos e custos resultantes desta programação, pois o modelo é desenhado em uma ambiente gráfico. Além disso, não há ferramentas computacionais no mercado que auxiliam na construção dos modelos com esta técnica.

\section{3) Sistema Cyclone (CYCLic Operations Network)}

Segundo Halpin e Riggs (1992), o sistema de modelagem Cyclone fornece um modo de análise, planejamento e controles quantitativos dos processos e operações de construção. Este sistema fornece uma base na qual as operações podem ser transformadas em simples fluxogramas, auxiliando no estudo das interações dos recursos necessários bem como na determinação das taxas de produtividade das tarefas.

Nos modelos do Cyclone, mão-de-obra, equipamentos, e material são modelados como unidades em fluxo. A tecnologia construtiva de uma operação de construção é incorporada na estrutura do processo do modelo, na composição das seqüências das tarefas, e no fluxo das unidades envolvidas no trabalho. Pela associação das durações das tarefas com as demais tarefas no modelo do Cyclone, o modelo é capaz de representar o período de tempo em que um recurso está envolvido em uma determinada sequiência de tarefas. Neste sentido, este 
modelo pode ser desenvolvido para a determinação das saídas operacionais e produtividade ao longo do tempo (HALPIN e RIGGS, 1992).

Como comentado pelos mesmos autores, apesar do produto final da construção ser único, os métodos usados na construção deste produto são na maioria das vezes repetitivos ou cíclicos na sua natureza.

O Cyclone fornece modelos de atividades repetitivas, que são características da construção de edifícios. No entanto, a utilização deste modelo não é muito difundida nas empresas construtoras.

Trabalhos como de Assumpção (1988), Lima Jr. (1990), Halpin e Riggs (1992), Silva (1993) e Ferreira (2001), entre outros, apresentam estudos mais completos das técnicas de programação utilizadas no ambiente da construção civil, bem como as vantagens e desvantagens na utilização destas técnicas. Fachini (2005) também apresenta diversas abordagens preconizadas para lidar com o planejamento da produção na construção de edifícios. Além disso, existem softwares de aplicação destas técnicas, o que auxilia a difusão da utilização nas empresas.

Kerzner (2002) os softwares disponíveis no mercado auxiliaram o planejamento pois:

a) constituíram a base de toda a programação, dando condições técnicas para programar melhor a alocação dos recursos para cumprir determinadas metas dentro das limitações dos prazos e do orçamento;

b) proporcionaram transparência;

c) proporcionaram facilidades na avaliação de alternativas;

d) proporcionaram a base a partir da qual se tornou possível reunir os fatos indispensáveis ao processo decisório;

e) utilizaram a chamada análise de rede de tempo como método básico para determinar a força de trabalho, o material e o capital necessários, e também para prover uma maneira de acompanhar o andamento do projeto; e

f) proporcionaram a estrutura básica para a elaboração de relatórios. 
No entanto, como enfatizado pelo autor, as técnicas de programação não podem substituir o planejamento. E as técnicas de programação, ou sequenciamento, não podem jamais ser mais importantes do que a qualidade das informações do plano.

Nas técnicas de programação apresentadas, as operações de produção precisam ser divididas em pacotes de trabalho, considerando os seguintes aspectos: localização do trabalho; habilidades necessárias para o trabalho; equipes envolvidas; recursos críticos; ações administrativas que necessitam de tempo; entregas ou aprovações que devem ser consideradas; e atividades especiais ligadas às propriedades físicas dos materiais ou procedimentos necessários. (HALPIN e WOODHEAD, 2004)

A divisão das operações de produção em pacotes de trabalho é elaborada a partir da estruturação e análise de uma matriz WBS (Work Breakdown Structure) da obra, ou EAP (Estrutura Analítica do Projeto) considerando Projeto no seu sentido mais amplo, ou seja, o empreendimento, conforme apresenta Assumpção (1996).

Assumpção (1996) explica que “o WBS é um procedimento de decompor a obra em subsistemas, estabelecendo hierarquias para esta decomposição. Como resultado obtém-se uma matriz que permite analisar a obra a partir dos seus subsistemas de hierarquia inferior". O autor complementa que, "no caso do modelo de programação, a decomposição será feita para identificar quais subsistemas estarão nele representados. Cada subsistema corresponderá a uma atividade da rede, o qual estará representando um conjunto de serviços de hierarquia inferior".

A partir da identificação e delimitação dos pacotes de trabalho, a duração de cada atividade é determinada em função da produtividade e balanceamento de recursos. (HALPIN e WOODHEAD, 2004)

Em toda a etapa de operação do processo de planejamento da produção não pode ser desconsiderado que na definição de um modelo também devem estar definidos os meios e procedimentos para se atingir as metas, reforça Assumpção (1996).

A segunda fase da operação do processo de planejamento da produção é o controle. Para se dar andamento a esta segunda fase é necessário que a base utilizada na estruturação do modelo de programação seja compatível com a que será utilizada para o sistema de controle. Por isso, “a matriz de serviços 'WBS' deverá ser a mesma, tornando-se necessário, portanto, 
olhar para o sistema de controle para se definir o de programação", ressalta Assumpção (1996).

Calvert, Coles e Bailey (1995) colocam que "o complemento do planejamento é o processo de controle, isto é, a comparação do desempenho atual com o planejado, a aplicação de ações corretivas quando e onde necessário, e o registro dos resultados para alimentar futuros planejamentos". Como também comentado pelos autores, controle "compreende as funções de contabilidade, orçamento, custos e registros, todas dependentes de coleta e acesso a informações confiáveis, de modo a permitir ações de curto prazo ou promover experiências de longo prazo".

Varalla (2003) coloca que a programação "resulta em um conjunto de diretrizes para a produção, e o controle representa a análise crítica dos resultados alcançados na produção para realimentar o processo" (Figura 2.11). O autor complementa que "a eficácia do sistema como um todo dependerá da velocidade com que as informações geradas no controle serão analisadas e das decisões a serem tomadas".

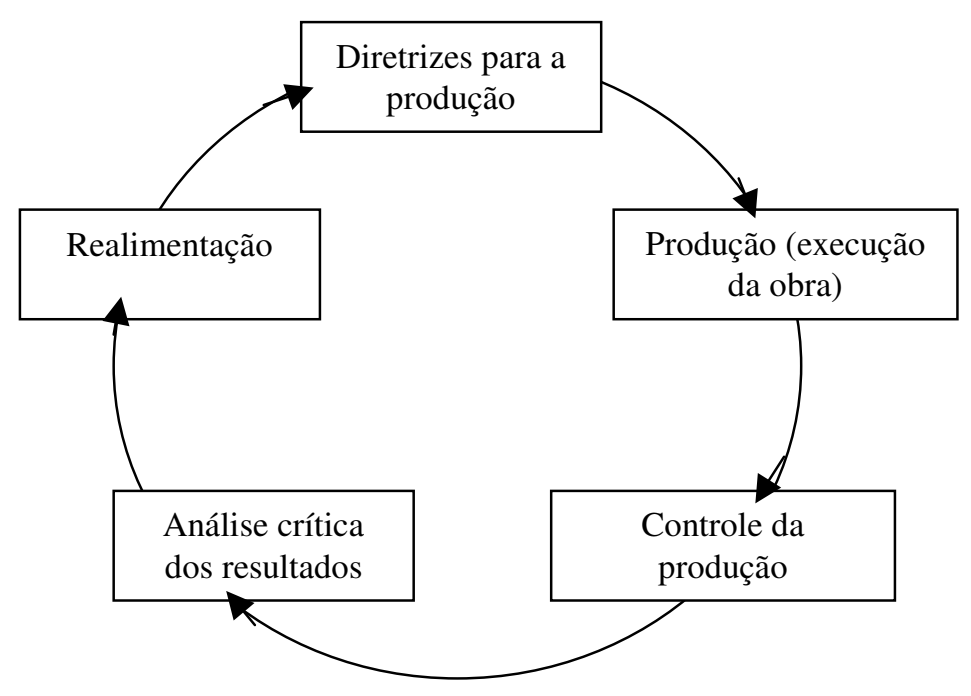

Figura 2.11 - Ciclo do planejamento (VARALLA, 2003)

Portanto, o sistema de controle do processo de planejamento da produção deve ser definido ainda na etapa de elaboração da programação, com o foco no caminho crítico da construção, conforme comentado por Varalla (2003).

Goldman (2004) também aponta que a fase de controle se dá durante a execução da obra. Por isso, este controle possibilita a coleta de dados e a conseqüente execução dos planos de curto 
prazo, que tornam a ação para eventuais desvios implantadas nos serviços ainda em andamento, e não a simples constatação de deficiências já ocorridas. Ou seja, a "qualidade deste controle está diretamente ligada à qualidade do planejamento previamente elaborado e à qualidade do acompanhamento físico-financeiro do empreendimento", segundo o autor.

As informações são obtidas do controle, e são avaliadas através da comparação das previsões e estudos da programação. As avaliações retroalimentam o processo de planejamento com uma nova entrada de dados, e quando os desvios interferem significativamente no prazo, custo e qualidade do empreendimento, os níveis de trabalho são atualizados e uma reprogramação do modelo pode ser realizada. (GOLDMAN, 2004)

Como enfatizado por Cleland (1988), variações na programação são resultado de estimativas inadequadas, controle inadequado da tarefa que deveria ser cumprida, baixa produtividade, ou inícios muito tarde das tarefas. $\mathrm{O}$ autor complementa que as variações devem ser analisadas para determinar o impacto no prazo e custo, visto que grandes variações podem exigir mudanças significativas na programação, enquanto variações menores podem apenas indicar que a situação deve ser monitorada. No entanto, o autor ainda comenta que qualquer mudança na programação irá provavelmente ser menos eficiente do que a programação original.

Varalla (2003) comenta que o funcionamento do planejamento proporciona à empresa a tomada de decisões em níveis de risco controlados, pois os processos são confiáveis e competitivos. As margens de lucro podem ser diminuídas, e a empresa melhorar sua representação no mercado.

Isso porque "a possibilidade de dominar os processos está relacionada à qualidade do sistema de planejamento [programação] e controle e à velocidade com que o controle age, registra, analisa e produz informações que realimentam o processo para tomada de decisões", afirma Varalla (2003). Isto posto, é reforçada a idéia de que o sistema de controle deve ser definido conjuntamente com o sistema de programação, com o estabelecimento do sistema de medição, registro e análise adequados.

O sistema de medição, registro e análise dos resultados é fundamental na detecção de problemas de produção. A forma como são realizados o acompanhamento da produção e a medição de produtividade deve ser capaz de detectar problemas em pontos específicos da obra, reforça Varalla (2003). 
Assumpção (1996) propõe, então, que o controle deve ser exercido sobre os principais serviços da obra. $\mathrm{O}$ autor ainda argumenta que "para tanto, é necessário que se atribuam pesos a estes serviços, caracterizando sua representatividade no processo de produção", sendo os pesos definidos por diferentes critérios, tais como a atribuição de pesos em função dos custos, ou do consumo de homens-hora, em relação ao total requerido para a obra.

Conforme enfatizado por Varalla (2003), a medição, que é o momento da coleta de dados realizada de forma sistemática, deve representar o momento do processo de produção, mostrando através das análises uma impressão global, e também direcionando a problemas pontuais que precisam de ações imediatas.

\section{4) Controle do processo}

O controle do processo de planejamento da produção é realizado através da análise e da validação do sistema de planejamento (programação e controle) pelos envolvidos, que vão desde a diretoria da organização, até as equipes de produção.

A análise e validação pela diretoria garantem que o processo de planejamento da produção é executado dentro dos conceitos e do programa do empreendimento, e é capaz de fornecer as informações necessárias para o processo decisório da alta gerência. Mais do que isso, dá condições para que o processo de planejamento realizado na hierarquia operacional seja aderente aos níveis superiores do planejamento.

Já a validação pelas equipes de produção e demais envolvidos, como a gerência de produção, analisa criticamente os critérios definidos no planejamento, a aceitação e o comprometimento com as metas estabelecidas.

A validação do sistema de planejamento, tanto a programação quanto o controle, é importante para obter o compromisso dos envolvidos, bem como garantir que a equipe entende o trabalho que deve ser executado. O planejamento do projeto irá solicitar colaboração entre os membros da equipe para desenvolver as soluções dos problemas e atingir as metas. (CLELAND, 1988) 


\section{5) Saídas}

As principais saídas do processo de planejamento da produção são informações: 1) referentes às metas, métodos e índices da programação; 2) referentes aos resultados alcançados e ações tomadas.

Um modelo de programação deve gerar informações sobre prazo, custos de produção, necessidades de insumos e volumes de produção, de acordo com Assumpção (1996). O autor também define que outras saídas do processo são o orçamento da obra, cronograma e especificações, que além de estruturar a empresa para a execução da obra, pode subsidiar a elaboração de contratos, a seleção e alocação de recursos, a definição de responsabilidades, a programação de investimentos, entre outros.

Calvert, Coles e Bailey (1995) afirmam que "para o planejamento ser eficaz, [este] deve ser simples, flexível, balanceado e baseado em dados precisos de desempenho determinados por análises sistemáticas de fatos observados e registrados. Planejamento é a mais importante ferramenta de gerenciamento, necessitando aplicação intensa, atenção aos detalhes, imaginação e conhecimento técnico, mas é sempre o meio e não o fim”. Os autores ainda ressaltam que "na sua aplicação, deve-se cuidar para com as necessidades humanas da organização".

As saídas do sistema de controle, as informações, devem, segundo Calvert, Coles e Bailey (1995): a) ser separadas conforme a responsabilidade; b) apresentar os resultados de maneira apropriada; c) ser apresentadas no período necessário; d) estarem disponíveis em tempo para que as decisões possam ser tomadas; e) despender o mínimo de energia da alta administração; e f) mostrar claramente os desvios do plano ou as exceções que aceitam tolerância.

Assumpção (1996) complementa que "o sistema de controle deve gerar informações sobre prazos, custos, e recursos, incorridos na produção, que permitam avaliar se as metas estão sendo cumpridas e se o desenvolvimento físico da obra está sendo compatível com os recursos já utilizados na sua execução".

Além disso, segundo Lima Jr. (1978), "um sistema de controle deve ter no seu bojo a capacidade da interação. Somente uma das áreas de ação é o controle de custos, onde poderá, até, estar o fulcro de todo o processo, porém, para que não se transforme num sistema paralelo à empresa, deverá estar integrado ao sistema de suprimento e seu controle, ao de 
planejamento financeiro e econômico e aos próprios sistemas primários da organização protocolo, contabilidade, caixa, etc".

Portanto, conforme mencionado por Goldman (2004), o planejamento deve apresentar análises em curto prazo, para que eventuais desvios sejam compensados, propiciando o mínimo de prejuízo.

Cabe aqui a discussão de que, como observado na descrição do processo de planejamento da produção, existem duas grandes etapas neste processo: uma primeira etapa que é desenvolvida antes do início da construção e compreende a formulação das diretrizes da obra; e uma segunda etapa que acontece já no canteiro de obras, pelos gerentes e equipes de produção, e que retroalimenta a primeira etapa, caracterizando o subsistema de controle. Portanto, o processo de planejamento da produção pode ser considerado como a atuação conjunta de dois subprocessos: um subprocesso de planejamento da produção inserido no fluxo de processos principais da organização; e um subprocesso de planejamento da produção integrante do fluxo de processos específicos do empreendimento. Estes dois subprocessos são complementares, e integrados pelo sistema de controle.

\subsubsection{Análise de interfaces e integração entre processos}

De acordo com Varalla (2003), o sistema de programação e controle é uma ferramenta fundamental na gestão da organização. Por isso, o processo de planejamento deve ser estabelecido como um dos processos principais do fluxo da empresa, e não como uma atividade isolada.

Como ressaltado por Goldman (2004), o processo de planejamento possui interfaces com quase todos os outros processos da empresa. Portanto, uma das funções do processo de planejamento, comenta Varalla (2003), é "identificar, analisar, questionar, melhorar, integrar os processos", ou seja, o processo de planejamento é um "processo integrador dos demais processos (internos e internos/externos)" e pode também ser considerado "uma ferramenta para gerenciar as interfaces com incorporação, projetos, suprimento, orçamentos, subcontratos, produção".

Os processos que interferem mais diretamente no processo de planejamento da produção, segundo diversos autores consultados, são: comercial, projetos, suprimento, financeiro, entrega de obra e assistência técnica e produtivo. Portanto, estes são os processos analisados 
na integração do processo de planejamento da produção no fluxo de processos da empresa construtora, como ilustrado na figura 2.12 .

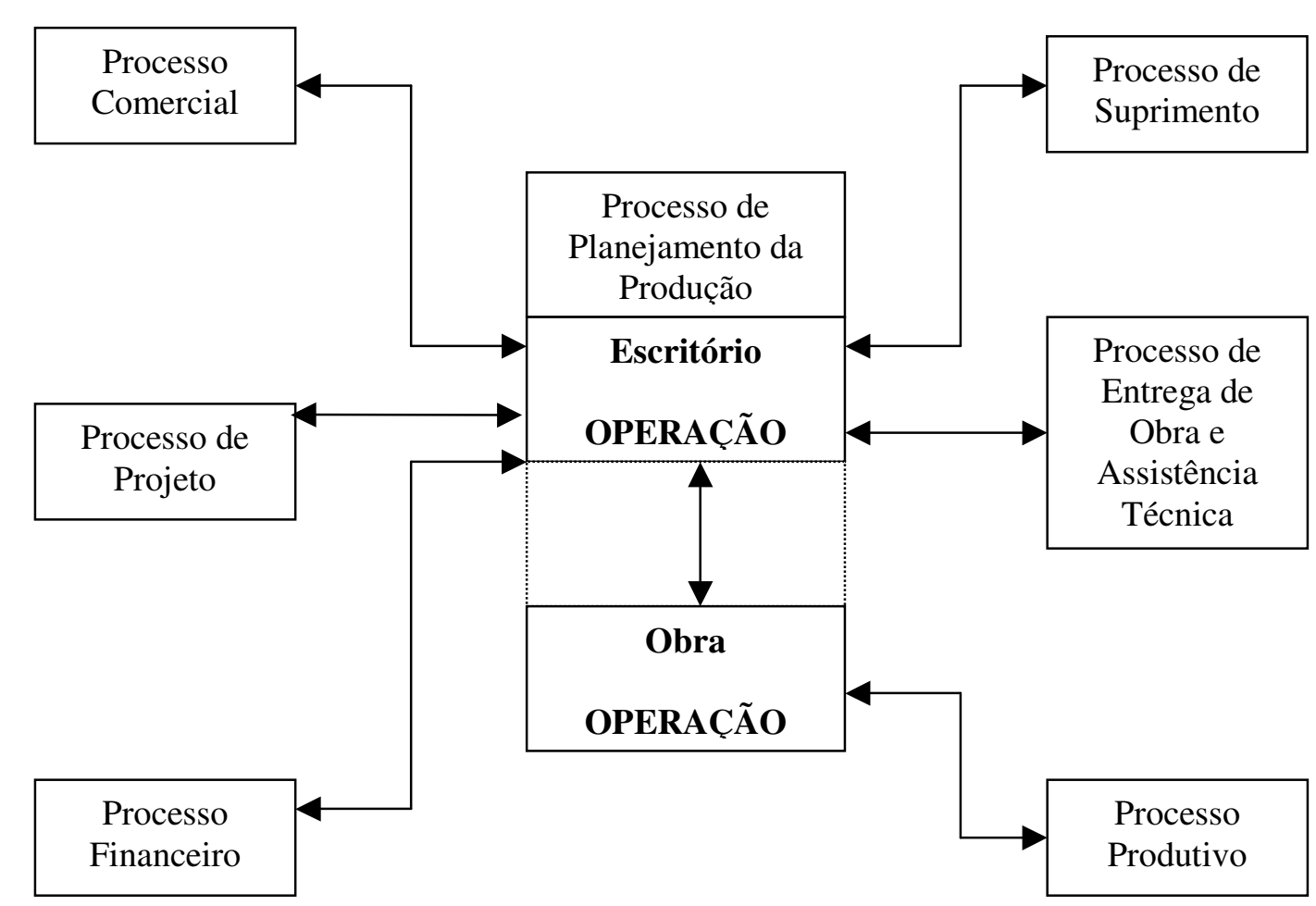

Figura 2.12- Gestão e integração do processo de planejamento da produção no fluxo de processos principais da empresa

\section{1) Processo de Planejamento da Produção x Processo Comercial}

O processo comercial é o principal responsável pelo estudo de viabilidade dos empreendimentos, em função de análises de custo estimadas utilizando índices de custo de produção por $\mathrm{m}^{2}$ de área construída, de acordo com Assumpção (1996). Com a viabilização do empreendimento, os custos estimados se transformam em metas de produção, que, conforme comentado pelo autor, se não cumpridas, podem comprometer a viabilidade do empreendimento.

Assumpção (1996) coloca que a realização do estudo de viabilidade sem consulta à equipe de produção pode gerar, entre outros problemas, custos de soluções fora do padrão provocadas por dificuldades construtivas na aplicação das soluções definidas no estudo de viabilidade. Ou seja, soluções inicialmente definidas e programadas no estudo de viabilidade não são de fato 
exequíveis no canteiro de obras. Isso pode acarretar alteração do sequenciamento das atividades de obra, e conseqüente alteração do fluxo econômico.

Outra dificuldade na integração do processo comercial com o processo de planejamento da produção apontada pelo mesmo autor é a definição do prazo da obra. O prazo da obra muitas vezes é definido pelo fluxo de caixa montado para viabilizar o empreendimento, e não pela capacidade do sistema de produção. Com isso, o sistema de produção através do planejamento da produção precisa adequar a construção à equação de fundos do empreendimento, sem atentar para o melhor aproveitamento dos recursos. Ou seja, segundo o autor, "isto leva a mudanças no ritmo e na trajetória de execução da obra, que devem ser ajustados para atender às condições de encaixe das receitas, quer sejam proveniente de vendas, quer sejam de financiamento para produção".

Por outro lado, a influência do processo de planejamento da produção sobre o processo comercial também é significativa. A qualidade do processo de planejamento da produção pode limitar ou incentivar a estratégica da empresa no mercado. A organização pode adotar posturas mais arrojadas quando seu processo de planejamento lhe dá o suporte necessário para garantir que sua produção atende os objetivos estabelecidos.

Isso é confirmado por Assumpção (1996), defendendo que o processo de planejamento, através de seus subsistemas de programação e controle, "devem ser estruturados para a busca do melhor desempenho no confronto com o mercado e o setor econômico no qual a empresa está inserida. Devem também ser construídos para dar suporte às decisões tomadas no ambiente interno da empresa, em seus níveis operacionais, que afetam diretamente a eficiência em custos de produção. O desempenho deste sistema, traduzido pela melhoria de produtividade, redução de custos de produção e melhor qualidade da construção, condiciona os riscos inerentes à produção, permitindo maior segurança na definição de preços e estratégias de comercialização".

Varalla (2003) também possui a mesma opinião que "empresas com sistemas de planejamento e controle funcionando adequadamente estarão em condições de diminuir margens de resultados, aumentando a competitividade, ou de garantir as margens e aumentar o lucro".

Outro aspecto que pode ser mencionado e está se tornando uma prática bastante comum em empreendimentos de alto padrão na Região Metropolitana de São Paulo, é a personalização dos apartamentos pelos clientes. As personalizações são utilizadas pelo processo comercial como apelo de marketing, mas afetam diretamente o processo de produção de um 
empreendimento. O sequenciamento dos serviços não consegue ser mantido, e é gerado grande volume de retrabalho. Com isso, dificilmente um modelo de programação consegue simular um cenário como este, e também causando efeitos no sistema de controle.

A aceitação de modificações pelo cliente deve ser considerada como umas das informações de entrada na elaboração da programação. Com isso, devem-se simular cenários com os tipos de modificações aceitas (por exemplo, alteração das vedações, dos acabamentos etc) ainda no estudo de viabilidade, considerando estes cenários na análise de risco do empreendimento. Assim, as interferências externas podem ser previstas e os impactos calculados na programação da construção, podendo também ser monitorados.

O quadro 2.2 apresenta o resumo da análise da interface do processo de planejamento da produção e do processo comercial.

Quadro 2.2 - Análise da interface do processo de planejamento da produção e do processo comercial

\begin{tabular}{|c|c|c|}
\hline Processo de planejamento da produção & $\mathbf{X}$ & Processo comercial \\
\hline $\begin{array}{l}\text { Elaboração de orçamentos e cronogramas } \\
\text { físicos para o estudo de viabilidade do } \\
\text { empreendimento }\end{array}$ & & Estudo de viabilidade do empreendimento \\
\hline $\begin{array}{l}\text { Elaboração da programação em função da } \\
\text { equação de fundos e não na alocação e } \\
\text { nivelamento dos recursos }\end{array}$ & & $\begin{array}{l}\text { Determinação do prazo da obra em função da } \\
\text { equação de fundos }\end{array}$ \\
\hline $\begin{array}{l}\text { Dá suporte ao processo comercial nas } \\
\text { estratégias de mercado }\end{array}$ & & $\begin{array}{l}\text { Posturas mais arrojadas com a confiabilidade no } \\
\text { sistema de planejamento }\end{array}$ \\
\hline $\begin{array}{l}\text { Interferência na definição das seqüências e } \\
\text { trajetórias em função de modificações pelo } \\
\text { cliente }\end{array}$ & & $\begin{array}{l}\text { Estratégia de marketing apoiada na opção de } \\
\text { modificações pelo cliente }\end{array}$ \\
\hline
\end{tabular}

\section{2) Processo de Planejamento da Produção x Processo de Projeto}

A interface mais crítica do processo de planejamento da produção é com o processo de projeto. Dificilmente há nas empresas a preocupação com a integração entre estes dois processos, que são fundamentais nas definições dos processos de produção, e que deveriam ser complementares. Estes processos são tão complementares que, no trabalho de Souza 
(2001), o processo de planejamento acontece na fase de Preparação da Execução de Obras (PEO), que integra projetos e obra.

Souza (2001) comenta que "somente um planejamento elaborado em coerência com o projeto torna-se 'ferramenta' para o acompanhamento da execução dos serviços".

Como forma de fundamentar as decisões de projeto nos conceitos do empreendimento estabelecidos no processo comercial, Fabrício (2002) coloca que deve ser elaborado um programa do empreendimento, estabelecendo as metas do negócio e requisitos para os projetos. $\mathrm{O}$ autor ainda explica que em geral são três tipos de requisitos tratados no programa: 1) as metas de negócio, referentes ao segmento de mercado ou demanda-alvo, seleção fundiária, custos do empreendimento, condições de financiamento, dependendo do tipo de empreendimento, velocidade de venda e rentabilidade desejada, etc.; b) requisitos funcionais, espaciais e operacionais que norteiem o desenvolvimento de produto; e c) requisitos de caráter construtivo como prazos, qualidade da obra, custos de construção, etc.

Este programa, como propõe Fabrício (2002), deve ser apresentado não só ao projetista de arquitetura, mas a todos os projetistas envolvidos no desenvolvimento do empreendimento, bem como aos responsáveis pelo planejamento e gerenciamento da produção. Assim, os agentes podem desenvolver seus trabalhos fundamentados em uma base única, que é o programa do empreendimento, ao invés de um trabalho ser originado com base no anterior, numa ordenação seqüencial do processo.

A falta de detalhamento dos projetos com relação a especificações, métodos construtivos e sequiências, faz com que estas características tenham que ser definidas pelo processo de planejamento da produção como, por exemplo, quando programações são elaboradas com base em projetos básicos ou ante-projetos. Em situação mais desfavorável, estas características também passam pelo processo de planejamento sem definição, e acabam sendo decididas pelo engenheiro de obra, mestres e oficiais, sem tempo e sem condições adequadas durante a construção, comenta Picchi (1993).

Como comentado por Fabrício (2002), “a partir dos anos 90 vários trabalhos de pesquisa têm analisado teoricamente a necessidade e a configuração dos 'projetos para produção' como ferramenta de planejamento da construção dos subsistemas da obra e como transposição entre o projeto do produto e a obra". 
Melhado (1994) define projeto para produção como um "conjunto de elementos de projeto elaborados de forma simultânea ao detalhamento do projeto executivo, para utilização no âmbito das atividades de produção em obra, contendo as definições de: disposição e sequiência de atividades de obra e frentes de serviço; uso de equipamentos; arranjo e evolução do canteiro; dentre outros itens vinculados às características e recursos próprios da empresa construtora".

Apesar dos estudos realizados sobre projeto para produção de diversos sistemas, como impermeabilização, laje racionalizada, revestimentos de fachada, entre outros, as empresas que já os utilizam ainda não têm a cultura de desenvolver estes projetos em simultaneidade com os projetos do produto, "o que inibe a interatividade com as soluções técnicas adotadas nos projetos do produto", afirma Fabrício (2002). O desenvolvimento tardio destes projetos não proporciona a integração com o processo de planejamento da produção, que acaba, muitas vezes, adotando soluções diferentes das solicitadas pelos projetos para produção.

Souza (2001) apresenta a metodologia de PEO como forma de "melhorar a comunicação, incentivar a participação e a colaboração entre os agentes". A autora ainda coloca que a PEO deve atender três condições: a) ser um trabalho coletivo, envolvendo os agentes responsáveis pelo projeto e pela execução, reduzindo os problemas de integração entre essas fases; b) ser um trabalho que conduza a antecipação das decisões, evitando que sejam tomadas no canteiro de obras, diante de uma necessidade de cronograma, sem considerar aspectos como custo, racionalização e desempenho; e c) ser um trabalho desenvolvido dentro de um tempo compatível com o atendimento de seus objetivos (constituir uma fase de interligação entre projeto e a obra, quando será possível estudar e planejar sua execução).

Varalla (2003) aponta como pontos negativos da falta de integração entre projeto, planejamento e obra as "interrupções não desejadas, aumentos de custo e o comprometimento da qualidade do produto".

A integração entre os processos de projeto, planejamento da produção e obra deve ser gerenciada, pois o inter-relacionamento destes três processos ocorre durante todo o ciclo de vida do empreendimento, como comentado por Goldman (2004).

O quadro 2.3 apresenta o resumo da análise da interface do processo de planejamento da produção e do processo de projeto. 
Quadro 2.3 - Análise da interface do processo de planejamento da produção e do processo de projeto

\begin{tabular}{|c|c|c|}
\hline Processo de planejamento da produção & $\mathbf{X}$ & Processo de projeto \\
\hline $\begin{array}{l}\text { Elaboração dos modelos com base no } \\
\text { programa do empreendimento e não apenas } \\
\text { nos projetos }\end{array}$ & & $\begin{array}{l}\text { Elaboração do programa do empreendimento e } \\
\text { projetos }\end{array}$ \\
\hline $\begin{array}{l}\text { Elaboração dos modelos considerando os } \\
\text { projetos para produção }\end{array}$ & & $\begin{array}{l}\text { Execução dos projetos para produção em } \\
\text { simultaneidade com os projetos do produto }\end{array}$ \\
\hline $\begin{array}{l}\text { Análise dos impactos das modificações no } \\
\text { modelo elaborado }\end{array}$ & & Controle de modifcações \\
\hline
\end{tabular}

\section{3) Processo de Planejamento da Produção x Processo de Suprimento}

Goldman (2004) afirma que "o setor de planejamento é em relação ao setor de compras o seu braço direito. Tanto serve de fornecedor como de controlador".

O processo de planejamento da produção é responsável por definir quando, quanto e como os recursos serão solicitados pela obra. A falta de integração entre os dois processos pode provocar interferências:

- no processo de suprimento: a falta da informação correta de quando, quanto e como os recursos serão alocados na obra pode prejudicar a negociação que deve ser realizada pelo processo de suprimento. A compra ou contratação em tempos insuficientes pode provocar aumentos de custos dos recursos por falta de negociação;

- no processo de planejamento da produção: a compra ou contratação dos recursos deve ser feita em concordância com as seqüências e pacotes de trabalho definidas no planejamento da produção. Compras ou contratações realizadas sem a análise do planejamento podem causar interferências na gestão dos recursos na obra, e conseqüente alteração das seqüências e soluções pré-estabelecidas para a construção. Neste aspecto, as contratações mais críticas com relação à análise do planejamento são os subempreiteiros.

Antes de justificar o aspecto crítico da contratação dos subempreiteiros, cabe apresentar os conceitos de seqüência e trajetória utilizados para caracterizar as ligações de dependência que existem entre os serviços, ou pacotes de trabalho, de uma construção vertical. Assumpção (1996) explica que "ligações de trajetória estabelecem dependências entre atividades de mesmo tipo, que se repetem de pavimento em pavimento", e "ligações de seqüência são 
utilizadas para dependências entre atividades de natureza diferentes, que são desenvolvidas dentro de um mesmo pavimento". O autor também coloca que "seqüência e trajetórias fazem parte da estratégia, ou plano de ataque, a ser utilizada para a execução da obra na região da torre".

De acordo com Fabrício (2002), as empresas construtoras recorrem cada vez mais à subcontratação de empreiteiros devido à facilidade de adaptação da estrutura produtiva da empresa a elevada variação de demanda por edificações no mercado, e também pela própria variação da quantidade e tipo de trabalho de cada fase do empreendimento. Com a subcontratação, os empreiteiros são mobilizados e desmobilizados conforme a necessidade da empresa e das fases do empreendimento.

Segundo o autor, "no processo construtivo, a utilização intensiva de mão-de-obra é viabilizada por uma estratégia agressiva de subcontratação de serviços fazendo com que parte significativa da produção seja delegada a terceiros".

Ohnuma (2003) complementa que "deve fazer parte do planejamento da produção, a análise da competência técnica do subempreiteiro para a execução de um serviço perante o seu conhecimento sobre uma determinada tecnologia inovadora". Para tanto, o autor ressalta a importância do processo de seleção para contratação, que precisa estar previsto na programação do empreendimento.

De acordo com Fabrício (2002), falhas no processo de seleção dos empreiteiros, somadas ao "precário domínio técnico das construtoras sobre suas atividades produtivas", que é decorrente da "ausência de um conhecimento formal sobre as técnicas construtivas (não existência de normas e procedimentos de execução) e sobre as seqüências de atividades de um serviço e seus respectivos tempos de duração", dificultam a adoção de procedimentos de controle da qualidade, "e a produtividade no canteiro fica sujeita a uma grande variabilidade de obra para obra e dependente das decisões tomadas em canteiro e do saber prático dos operários". O autor comenta que com a implementação de sistemas de gestão da qualidade, as empresas conseguiram padronizar e criar procedimentos para seus processos, "ampliando sensivelmente o seu domínio técnico sobre os processos produtivos".

Como forma de facilitar a integração dos subempreiteiros e do sistema de planejamento, Ohnuma (2003) propõe que sejam considerados dois processos distintos e interdependentes: 1) a análise e atualização do orçamento da obra pelos contratos dos subempreiteiros; e 2) a análise e atualização da programação e controle da obra pelos contratos dos subempreiteiros. 
O autor também ressalta a importância da definição clara de responsabilidades nos contratos para uma gestão eficiente da produção.

A contratação dos subempreiteiros considerando o orçamento e programação, e a posterior análise destas ferramentas, evitam problemas de definição de escopo e de integração entre os serviços. A desconsideração das sequiências e trajetórias na fase de contratação pode interferir sensivelmente na estratégia da obra, e conseqüentemente na equação de fundos montada para viabilizar o empreendimento. Problemas de contratação não afetam apenas o custo do serviço diretamente contratado, mas sim podem afetar o desempenho do empreendimento como um todo.

Ohnuma (2003) aponta o problema das interfaces entre contratações. Segundo o autor, problemas de interfaces entre serviços são dependentes de efetiva coordenação, pois os serviços subempreitados são, na maioria das vezes, interdependentes na sua trajetória e sequência.

O autor ainda coloca que "o envolvimento com diversos subempreiteiros condiciona a empresa construtora a compatibilizar os processos de gestão de contrato, de medição e de pagamento do serviço. Assim, é possível controlar eficientemente o fluxo de caixa da obra com a gestão das interfaces entre os serviços ou durante o momento de entrada e saída dos subempreiteiros do canteiro de obras. O contrato e o cronograma físico-financeiro devem servir como instrumentos de gestão dos subempreiteiros aos engenheiros de obras".

O quadro 2.4 apresenta o resumo da análise da interface do processo de planejamento da produção e do processo de suprimento.

Quadro 2.4 - Análise da interface do processo de planejamento da produção e do processo de suprimento

\begin{tabular}{|l|l|l|}
\hline \multicolumn{1}{|c|}{ Processo de planejamento da produção } & $\mathbf{X}$ & \multicolumn{1}{c|}{ Processo de suprimento } \\
\hline $\begin{array}{l}\text { Definição dos prazos e quantidades dos } \\
\text { recursos }\end{array}$ & $\begin{array}{l}\text { Definição correta dos recursos auxilia na } \\
\text { negociação }\end{array}$ \\
\hline $\begin{array}{l}\text { Interferência nas seqüências devido à } \\
\text { contratações sem análise da programação } \\
\text { (interferências nos escopos das contratadas) }\end{array}$ & $\begin{array}{l}\text { Compras e contratações baseadas nas seqüências } \\
\text { e pacotes de trabalho (definição clara do escopo) }\end{array}$ \\
$\begin{array}{l}\text { Sistema de controle integrado ao sistema de } \\
\text { medição de fornecedores }\end{array}$ & $\begin{array}{l}\text { Critérios de medição estabelecidos em contrato } \\
\text { de acordo com o sistema de controle }\end{array}$ \\
\hline
\end{tabular}




\section{4) Processo de Planejamento da Produção x Processo Financeiro}

Os processos e estratégias de produção, e os prazos definidos por estes, devem atender a equação de fundos montada para viabilizar o empreendimento, minimizando os investimentos no período de construção, como coloca Assumpção (1996).

Na montagem da equação de fundos, o orçamento e a programação do fluxo de gastos são fundamentais. Como comentado por Fabrício (2002), "a capacidade de orçar e planejar os fluxos de gastos e receitas é estratégica na condução do empreendimento". No entanto, estes orçamentos e programação inicial são elaborados a partir do programa de necessidades, e só posteriormente são refinados a partir dos projetos e na obra, como complementado pelo autor.

Fabrício (2002) ainda comenta que "paradoxalmente, como cada empreendimento é único e os dados e metodologias paramétricas da maioria das empresas são precários, uma previsão confiável dos custos só é possível após uma série de levantamentos, sondagens e da existência dos projetos detalhados. Em contraste, a disponibilidade e a qualidade dos dados disponíveis no início da concepção do empreendimento são limitadas, obrigando a utilização de dados históricos e paramétricos para geração das estimativas".

Goldman (2004) reforça que “o orçamento detalhado da obra é, sem dúvida, a mais importante ferramenta para o planejamento [programação] e acompanhamento dos custos de construção". Varalla (2003) complementa que o orçamento "é o elemento de referência para o planejamento [programação] e o controle da produção e para a orientação e o controle da gestão das compras".

No acompanhamento do progresso do empreendimento, o sistema de controle deve ser capaz de gerar dados tanto de progresso físico quanto de custos.

No controle de custos, a definição dos centros de custos deve ser realizada "com base na divisão do empreendimento em unidades de controle significativas, cada uma delas consistindo em um certo tipo de trabalho que pode ser medido no campo", de acordo com Halpin e Woodhead (2004).

Segundo os autores, "o conceito de uma unidade comum no empreendimento que integra tanto o planejamento como o controle de custos levou ao desenvolvimento da abordagem da divisão do trabalho. O denominador comum básico neste esquema é o pacote de trabalho, que é um subelemento do empreendimento em que os dados referentes a custos e prazos são 
coletados para a produção de relatórios de andamento do empreendimento. A coleta de dados de custos e tempo com base em pacotes de trabalho gerou o termo gerenciamento integrado de empreendimentos". Este conjunto de pacotes de trabalho constitui a estrutura do WBS do empreendimento, já discutido em seção anterior.

A estrutura tradicional dos orçamentos com os centros de custos formados pelos principais serviços de obra nem sempre auxilia na gestão do empreendimento, e acompanhamento do progresso da obra. Segundo Varalla (2003), seria interessante que o orçamento identificasse “os vários ciclos de atividades através dos quais será desenvolvido o trabalho". Com isso seria possível a integração do orçamento, do sistema de controle de custos e do sistema de programação mais aderente aos ciclos de produção.

Além do controle dos custos na gestão do empreendimento, este controle deve ser capaz de retroalimentar o banco de dados, que darão origem a orçamentos e estudos de viabilidade de novos empreendimentos. (HALPIN e WOODHEAD, 2004)

O quadro 2.5 apresenta o resumo da análise da interface do processo de planejamento da produção e do processo financeiro.

Quadro 2.5 - Análise da interface do processo de planejamento da produção e do processo financeiro

\begin{tabular}{|c|c|c|}
\hline Processo de planejamento da produção & $\mathbf{X}$ & Processo financeiro \\
\hline $\begin{array}{l}\text { Processos construtivos e estratégias de } \\
\text { produção devem atender à equação de fundos }\end{array}$ & & Estudo da equação de fundos (fluxo de caixa) \\
\hline $\begin{array}{l}\text { Divisão dos pacotes de trabalho considerando } \\
\text { o controle de custos e prazo }\end{array}$ & & $\begin{array}{l}\text { Definição dos centros de custos com a mesma } \\
\text { estrutura básica da programação e controle } \\
\text { (WBS) }\end{array}$ \\
\hline Alimentação do banco de dados de custos & & Manutenção do banco de dados de custos \\
\hline
\end{tabular}

\section{5) Processo de Planejamento da Produção x Processo de Entrega de Obra e Assistência}

\section{Técnica}

O processo de entrega de obra é raramente inserido na programação da obra, sendo que este é um processo extremamente importante para garantia da qualidade final do produto que é entregue ao cliente. 
Cabe ressaltar o comentário de Kerzner (2002) sobre a definição de sucesso de um empreendimento: o sucesso pode ser mensurado em termos de fatores primários e secundários, tais como:

a) fatores primários: empreendimento no prazo, dentro do orçamento, com a qualidade do produto desejada;

b) fatores secundários: aceitação do empreendimento pelo cliente; principal demonstração da aceitação do produto pelo cliente e da satisfação é quando o cliente concorda com a utilização de seu nome como referência.

O quadro 2.6 apresenta o resumo da análise da interface do processo de planejamento da produção e do processo entrega de obra e assistência técnica.

Quadro 2.6 - Análise da interface do processo de planejamento da produção e do processo de entrega de obra e assistência técnica

\begin{tabular}{|c|c|c|}
\hline Processo de planejamento da produção & $\mathbf{X}$ & $\begin{array}{c}\text { Processo de entrega de obra e assistência } \\
\text { técnica }\end{array}$ \\
\hline $\begin{array}{l}\text { Previsão das atividades de inspeção final e } \\
\text { entrega de obra na programação }\end{array}$ & & $\begin{array}{l}\text { Definição dos prazos de inspeção final e entrega } \\
\text { de obra, bem como documentação e aprovações } \\
\text { necessárias }\end{array}$ \\
\hline $\begin{array}{l}\text { Garantia de atendimento aos requisitos do } \\
\text { cliente }\end{array}$ & & Verificação dos requisitos do cliente \\
\hline
\end{tabular}

\section{6) Processo de Planejamento da Produção x Processo Produtivo}

A análise da interface entre estes dois processos trata, principalmente, do desdobramento do planejamento operacional nos três níveis de decisão: longo, médio e curto prazo.

Fachini (2005) comenta que já é consenso nas empresas a importância do planejamento operacional no longo e médio prazo, mas que são poucas as empresas que estruturam o planejamento operacional no curto prazo. Quando o planejamento atinge o nível de curto prazo, "detecta-se uma carência quanto ao detalhamento dos serviços, deixando de ser útil para a produção", coloca a autora. No entanto, com a melhoria dos processos executivos das obras, o planejamento operacional de curto prazo "tem sido sensivelmente valorizado e a necessidade de implantá-lo é cada vez mais intensa", segundo a mesma autora. 
No entanto, o planejamento operacional de curto prazo que é transmitido à equipe de produção através da definição de metas diárias ou semanais, por exemplo. Também é neste nível que são definidos a alocação dos recursos, como mãos-de-obra e materiais, às tarefas e atividades. Ou seja, o planejamento operacional de curto prazo é o nível do planejamento mais próximo a execução, mas é o nível que mais é negligenciado, ou pela definição informal ou pela delegação aos subempreiteiros e fornecedores.

O quadro 2.7 apresenta o resumo da análise da interface do processo de planejamento da produção e do processo produtivo.

Quadro 2.7 - Análise da interface do processo de planejamento da produção e do processo produtivo

\begin{tabular}{|l|l|l|}
\hline \multicolumn{1}{|c|}{ Processo de planejamento da produção } & $\mathbf{X}$ & \multicolumn{1}{c|}{ Processo produtivo } \\
\hline \hline $\begin{array}{l}\text { Definição do planejamento operacional de } \\
\text { médio e curto prazo (metas de médio e curto } \\
\text { prazo com alocação dos recursos) }\end{array}$ & & Cumprimento das metas de médio e curto prazo \\
\cline { 1 - 1 } & & Monitoramento da produtividade e consumos \\
\hline
\end{tabular}

\subsubsection{Gestão do processo de planejamento da produção}

Considerando o conceito adotado de "gestão" como o conjunto de ações de planejamento, organização das competências, responsabilidades e autoridades, comunicação, controle, tomada de decisão e melhoria, é analisado o processo de planejamento da produção.

Na gestão do processo de planejamento da produção, a fase de planejamento do processo é que dirige o desenvolvimento das ações que são tomadas ao longo do processo. A definição dos momentos de atuação, dos modelos utilizados e grau de detalhamento, da equipe técnica alocada e os graus de responsabilidade e autoridade, e do fluxo de informação, garantem a aderência do processo de planejamento da produção ao fluxo de processos principais da empresa, e ao empreendimento a que este se aplica.

O sistema de planejamento envolve "uma série de ações que devem fazer parte de um processo dentro da empresa", e estas ações devem ser gerenciadas, garantindo a eficácia do processo, explica Varalla (2003). 
O processo de planejamento não pode ser entendido como apenas a elaboração do modelo e da programação do empreendimento. Esta falha de conceitos é devido a ênfase dada na execução da programação, comenta Laufer e Tucker (1987). Isso acontece, segundo os autores, devido ao foco principal no prazo, e a pouca preocupação com a alocação dos recursos e com a equação de fundos do empreendimento. Deste modo, o principal fator do sistema de planejamento, que é a definição do método construtivo, não é pensada.

Laufer e Tucker (1987) ainda colocam que o detalhamento do planejamento que na maioria das situações é realizado já na obra, não atende ao objetivo do processo de planejamento da produção, que é o estudo dos métodos em uma análise global e integrada dos processos da empresa e do empreendimento.

A definição da equipe de trabalho do processo, as competências necessárias, suas responsabilidades e autoridades dentro do fluxo de processos da empresa e do empreendimento, determinam a gestão do processo de planejamento da produção. A gestão do processo executada por indivíduos sem autoridade sobre o que estão planejando, sem responsabilidades assumidas de suas atividades, tornam a gestão do processo ineficiente, pois não atuam efetivamente sobre o contexto no qual estão inseridos.

Como já decorrido em seções anteriores, a aderência do processo de planejamento nos níveis hierárquicos da organização é importante na configuração do sistema de controle e de comunicação. A gestão das informações ao longo do processo de planejamento da produção permite a confiabilidade nas entradas e saídas do processo, e na tomada de decisões pelos diversos níveis hierárquicos.

\subsubsection{A subcontratação do processo de planejamento da produção}

De acordo com Fabrício (2002), a descontinuidade dos ciclos de produção e as oscilações de demanda por edificações no mercado, tornam difícil a manutenção, pelas empresas construtoras, de equipes internas de determinados serviços de engenharia como projetos e planejamento. Estas equipes, na maioria das vezes, "representa investimentos com os quais a maioria das empresas não pode e não se interessa em arcar", comenta o autor.

Goldman (2004) comenta que as empresas construtoras estão revendo sua estrutura organizacional, reduzindo ou até mesmo eliminando alguns departamentos, optando pela subcontratação parcial ou total dos serviços realizados pelo departamento. Com isto, verifica- 
se a formação de um setor independente constituído por prestadores de serviços de engenharia, tais como projeto, planejamento e serviços de consultoria, que atuam como fornecedores externos, dando suporte ou substituindo os processos internos da empresa construtora, complementa Fabrício (2002).

Como ressaltado por Fabrício (2002), “as atividades desenvolvidas nessas empresas requerem a atuação, preponderantemente, de profissionais com formação universitária e de técnicos especializados, cuja formação acadêmica requer pesados investimentos e tempo significativo de estudos".

Apesar do valor agregado que estes serviços têm incorporado, e da importância da formação dos profissionais, muitas vezes estes serviços são contratados segundo critérios de preço, sem avaliação da qualidade do fornecedor que está sendo contratado, comenta o autor. Com isso, o serviço especializado é visto como custo, quando na verdade deveria ser considerado um investimento cujos retornos se darão na maior eficiência da produção e na melhor qualidade do produto final.

Outro aspecto fundamental na análise da subcontratação dos serviços que fazem parte do processo da empresa, é a integração deste agente no ambiente da empresa e do empreendimento. Este agente subcontratado promove a inserção na empresa e no empreendimento da especialização do trabalho. No entanto, se este agente é inserido em um ambiente sem a análise da integração deste serviço em um contexto pré-existente, o aproveitamento é muito baixo, podendo até mesmo causar efeitos negativos no fluxo de processos da empresa. Além disso, a inserção deste agente na estrutura da empresa sem a atribuição de responsabilidades e autoridade para sua atuação, não o tornam parte integrante do processo.

Ohnuma (2003) comenta que a subcontratação na indústria é um aspecto fundamental e valorizado, que proporciona maior competitividade através da redução dos custos, maior qualidade, acesso a novas tecnologias e foco no negócio. No entanto, como também observado pelo autor, na indústria existe a preocupação com a integração das atividades especializadas junto às subcontratadas, garantindo, assim, a utilização racional dos diversos recursos adquiridos, sejam estes tecnologias, recursos, ou conhecimentos.

Por isso, sendo cada vez mais freqüente a subcontratação nas empresas construtoras, torna-se cada vez mais importante a coordenação e integração das atividades internas e de seus fornecedores. A gestão por processos auxilia nesta integração, visto que, segundo Ohnuma 
(2003), a “mudança de paradigma de 'funções' para 'processos' permite às empresas gerenciar o fluxo de trabalho continuamente, através da visão do cliente-fornecedor de cada processo".

\subsubsection{Competência do planejamento e competência de gestão}

Como apresentado por Halpin e Woodhead (2004), os três aspectos mais importantes de sistema de planejamento são o controle do tempo, do custo e do escopo, sendo a qualidade resultante do controle destas três variáveis.. Portanto, um sistema de planejamento deve ser competente no tratamento destas três variáveis, que são função da qualidade da informação com que o sistema é gerado, e também determina a qualidade da informação que o sistema gera.

No entanto, o sistema de planejamento é uma ferramenta do processo de planejamento. A gestão do processo de planejamento, com a organização do sistema, a aplicação, a comunicação, os controles sobre o processo, e as ações de melhoria, é que fazem com que o sistema funcione e garanta o cumprimento dos requisitos do produto, no caso o empreendimento, e dos objetivos definidos nos níveis operacional, tático e estratégico. $\mathrm{O}$ atendimento aos objetivos propostos nos três níveis só é possível através da integração dos processos da empresa.

\subsection{GESTÃO DA INFORMAÇÃO}

De acordo com Vasconcellos e Hemsley (1997), “comunicação é o processo através do qual uma mensagem é transmitida de um ponto chamado emissor para outro denominado receptor, através de um determinado canal”. Em uma estrutura organizacional, a comunicação pode se dar horizontalmente e verticalmente: quando a comunicação segue a cadeia de autoridade, ela é denominada vertical; quando o fluxo de comunicação não passa pelos gerentes dos departamentos, e acontece entre indivíduos de unidades diferentes, é denominada horizontal.

Segundo Calvert, Coles e Bailey (1995), comunicação é o meio empregado pelo líder para se fazer conhecer seus objetivos e inspirar os esforços necessários; é o meio empregado pelos executivos para transmitir seus planos e instruções para a ação; e pelos supervisores para coordenar atividades e controlar as operações. Mais do que isso, a comunicação promove um melhor entendimento através da descrição do que está sendo feito e o motivo pelo qual está 
sendo feito, permite a livre expressão de sugestões por todos os níveis da hierarquia, estimula o senso de participação e previne a pressão de suspeitas e desentendimentos, estes contribuindo para a manutenção da saúde moral dos indivíduos.

Calvert, Coles e Bailey (1995) complementam que apesar da comunicação ser uma ferramenta indispensável de liderança e supervisão, também a habilidade para transmitir mensagens claramente, com energia e convicção, tanto por discurso quanto pela escrita, é a chave do exercício do poder entre pessoas civilizadas.

Souza (2001) comenta que existem duas regras básicas para um bom funcionamento de uma troca de informações: "de início, é necessário que os agentes estabeleçam os meios de comunicação e seu modo de funcionamento; em seguida, que os papéis dos agentes sejam claramente definidos e que cada um aceite o papel que lhe foi destinado". A autora também coloca que "é importante entender a palavra comunicação no sentido de 'dividir algo', e não no de 'conhecer' ou 'informar algo'. É necessário que os agentes cooperem verdadeiramente, que possuam um conjunto de dados, a partir dos quais cada um passe a assumir a missão que lhe é confiada".

Os sete estágios da comunicação são apresentados por Calvert, Coles e Bailey (1995), e ilustrados na figura 2.13. A idéia do emissor é convertida em mensagem que é transmitida para o receptor, decodificando e entendendo a mensagem. Ou autores também colocam que, em negócios, este entendimento normalmente significa uma ação específica.

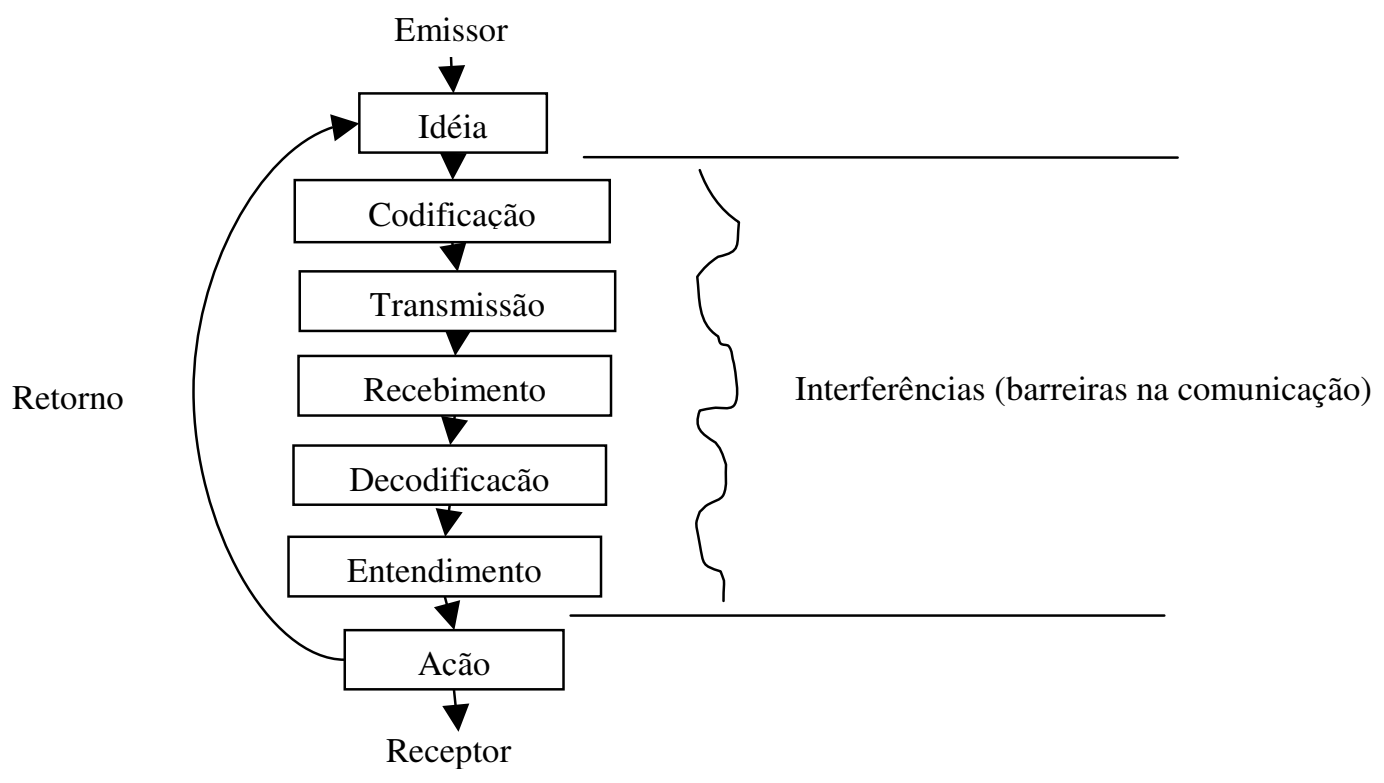

Figura 2.13 - Os sete estágios do processo de comunicação (adaptado de Calvert, Coles e Bailey (1995)) 
As barreiras da comunicação, segundo os autores, podem ser caracterizadas como: a) desvio na percepção do receptor (informações negativas são filtradas ou distorcidas pelos agentes intermediários); b) omissão (emissor não transmite itens importantes da informação deliberadamente ou propositalmente); c) falta de confiança (tendência a não aceitar a informação, principalmente quando o emissor não é confiável); d) elementos não-verbais da informação (mensagem recebe interpretação não pela mensagem em si mas pelo modo como é transmitida, por exemplo, a expressão corporal); e) excesso de informação (muita informação faz com que o receptor não consiga considerar toda a informação); f) segregação de informação (mal uso do poder para esconder informações ao invés de dividi-la); g) distância (pode ser geográfica, mas muitas vezes envolve a distância pelo número de pessoas na cadeia de comunicação); h) posição hierárquica (posições mais próximas conseguem mais informações dos chefes); i) momento (por exemplo, telefone pode interromper discussões que são mais importantes); j) tática de conflito (utilização da informação como moeda de troca); k) falta de clareza (uso de jargões ou palavras erradas sempre atrapalham o estágio de codificação e transmissão).

Em um empreendimento, uma das barreiras é a falta de efetiva coordenação das atividades. De acordo com Souza (2001), informações geradas ao longo das fases de concepção e execução são perdidas devido à ausência de efetiva coordenação. Isso porque "no caso da construção de edifícios, composta por várias organizações, as possibilidades de constituição de canais [de comunicação] são significativas. Com isso, a coordenação dessa série de informações geradas pelos diversos canais de comunicação pode ser considerada como uma atividade imprescindível a ser trabalhada em cada organização e entre elas”.

Lima Jr. (1978) também ressalta a utilização dos canais de comunicação para promover a integração da organização. Através do sistema de controle que possui seus ramos nos diversos níveis hierárquicos, e da informação necessária no momento requerido, é possível a integração da organização em uma avaliação global dos objetivos buscados.

De acordo com Murgel (1981), sistema de informação é aquele que "cuida dos processos e procedimentos de informações necessárias a levar rapidamente ao conhecimento dos níveis de decisão os 'indicadores gerenciais', bem como, tornar conhecidas com rapidez as decisões tomadas". 
Ohnuma (2003) explica que um processo possui dois tipos de fluxos de informação, que interagem internamente ao processo no momento da tomada de decisões:

“a) fluxo de informações primário: flui na horizontal como uma entrada do processo (entrada primária) e gera uma saída (saída de valor) que é o resultado esperado decorrente da tomada de decisão que envolve as 'atividades de transformação' internas ao processo. Sua 'entrada' é caracterizada por documentos que irão passar por um processo de avaliação na empresa, como por exemplo: planilhas, contratos, fichas de avaliação, notas fiscais, etc.

b) fluxo de informações de apoio: flui na vertical como uma 'entrada de apoio' e serve para auxiliar/orientar as pessoas no momento da tomada de decisão. (...) a 'saída de controle' objetiva retroalimentar o início do fluxo de informações 'de apoio', que também pode ser conduzido por um sistema da qualidade e por um sistema de planejamento. Quanto a 'entrada de apoio', esta é caracterizada por documentos ou instrumentos de gestão, como: procedimentos gerenciais e administrativos, manuais, instruções de trabalho, normas internas, etc.".

Portanto, a informação serve como meio de comunicação e controle das atividades, e suporta a programação, o controle e a tomada de decisões em uma organização, coloca Ohnuma (2003). Como ressaltado por Davenport (1994), as empresas devem gerenciar as informações de modo a orientar e acompanhar o desempenho dos processos, integrando as atividades.

De acordo com Davenport (1994), “apenas o acréscimo da informação num processo pode, por vezes, levar a melhorias radicais de desempenho. Ela pode ser usada para medir e acompanhar o desempenho de processos, integrar atividades dentro e através dos processos, personalizar processos para determinados clientes e facilitar o planejamento e a otimização dos processos à longo prazo". Deste modo a informação deve ser orientada para o processo, apoiando análises em tempo real da qualidade das atividades.

Mais importante que a quantidade de informação em um processo, é a qualidade desta informação. Segundo Souza (2001), "a qualidade do sistema de informação está ligada principalmente à velocidade com que a informação chega ao pólo de decisões e ao seu conteúdo, ou nível de detalhamento", ou seja, "o conteúdo e a forma como as informações se apresentam têm que guardar uma correspondência com o nível de decisão a que se destinam".

Segundo Assumpção (1996), “em empreendimentos de construção civil, a disponibilidade de informações a manipular aumenta, à medida que se avança nas diferentes etapas do seu ciclo 
de vida". Ou seja, o detalhamento das informações aumenta a medida que se passa do planejamento de longo para médio prazo, e conseqüentemente o modelo também precisa ser mais detalhado.

A utilização de modelos detalhados, ou seja, a manipulação de informações detalhadas nos níveis de longo e médio prazo, de acordo com Assumpção (1996), "não confere qualidade às decisões, uma vez que as informações para operar com estes modelos, nem sempre estarão disponíveis, por terem origem em projetos e especificações ainda não elaborados”. Com isso, são inseridas informações no modelo que não possuem base sólida, mas partem da suposição do planejador. Desta forma são inseridos riscos no estudo do modelo, pois não há uma base sólida de análise destas informações, que possuem uma baixa qualidade intrínseca visto que não é possível conhecer o comportamento das variáveis mas apenas especular sobre seu andamento.

O autor ainda ressalta que "apesar disso, é comum a associação de que a qualidade das informações geradas pelo planejamento é tanto melhor quanto maior for o número de informações manipuladas. Assim, a tendência acaba sendo a de procurar modelos mais detalhados, ou complexos, mesmo quando para gerar informações para níveis mais elevados de decisão".

Além da preocupação com o grau de detalhamento da informação, o tipo e fonte da informação também interferem na qualidade do modelo, principalmente quanto aos indicadores de custo e produtividade inseridos para a modelagem dos cenários.

Os indicadores publicados por revistas especializadas, que não são orientados por um critério padrão e sem correlação com programas de produção e tratamento estatístico, são questionáveis, segundo Assumpção (1996). Estas informações inseridas no modelo, também prejudicam a qualidade das informações geradas, além de inserir um risco devido à adoção de critérios que não são praticáveis, tanto com relação a custos quanto a produtividade, podendo inclusive comprometer a viabilidade do empreendimento.

Fachini (2005) também coloca que "para se obter confiabilidade nos prazos previstos no cronograma físico, é fundamental ter-se confiança nos índices de produtividade, pois, durante a elaboração do planejamento, esses índices são necessários para se conseguir prever os prazos para execução das atividades". A autora também ressalta que "em muitas empresas, os indicadores de produtividade foram obtidos através de coleta realizada por estagiários, da extração de valores de um manual de orçamentação, como o TCPO (Tabela de Composições 
de Preços para Orçamentos), de índices estimados por engenheiros da empresa, números que, muitas vezes, são majorados ou não conseguem atender à expectativa de execução do serviço, dificultando a confiabilidade na previsão dos prazos para execução".

Apesar de o setor se mobilizar no estudo de indicadores confiáveis ${ }^{10}$, a fonte mais fiel de informações é a própria empresa, que possui um histórico próprio de métodos construtivos e níveis alcançados. Para isto, segundo Assumpção (1996), a empresa deve criar critérios e procedimentos padronizados para a coleta destes indicadores, e o banco de dados é formado pelo acompanhamento da evolução destes indicadores ao longo do tempo, no ambiente interno da empresa. De acordo com o autor, estes indicadores "além de medirem a evolução do sistema de produção servem para calibrar as referências utilizadas para a programação da produção".

Souza (2001) também aponta para a necessidade da criação de um banco de dados com a memória construtiva da empresa. Para a autora, a memória construtiva é "uma 'ferramenta' de gestão fundamental para a constituição da documentação técnica". Isto pois "a importância da constituição da memória construtiva da empresa, destinada a ser consultada, principalmente, pelos coordenadores de projeto e pelos coordenadores de obras, está em sistematizar as informações já avaliadas e utilizá-las em novos empreendimentos, visando sempre a melhoria contínua do processo de produção". Este banco de dados acaba por auxiliar no gerenciamento do conhecimento da empresa.

Segundo Fischer (2005b), o conceito de gestão do conhecimento é recente tanto na literatura quanto na prática organizacional. Por isso, são encontradas diversas definições, e pode ser considerado como um conceito em construção, de acordo com Perrotti (2004). O autor ainda coloca que a própria definição de conhecimento é controversa. Aqui é apresentada uma definição de conhecimento e de gestão do conhecimento, visto que não é objetivo do trabalho esgotar o assunto, mas apenas entender os significados para subsidiar a análise da gestão.

De acordo com Davenport e Prusak (1998), dados são um conjunto de fatos distintos e objetivos, relativos a eventos; nas organizações, são descritos como registros de operações. Portanto, dados descrevem parte de algum evento, não possuindo significado inerente, não fornecendo interpretação ou base para tomada de decisão.

\footnotetext{
${ }^{10}$ Diversas pesquisas vem sendo elaboradas com o intuito de melhorar a qualidade dos indicadores. Neste sentido, destacam-se as pesquisas de indicadores de produtividade realizadas pela Escola Politécnica da Universidade de São Paulo, e pelo NORIE da Universidade Federal do Rio Grande do Sul.
} 
Os dados formam a informação. Segundo os mesmos autores, a informação possui mensagem e como qualquer mensagem possui um emissor e um receptor. A informação causa impacto sobre o julgamento e comportamento do receptor. No entanto, a informação não é suficiente para a ação. Para isto é necessário o conhecimento, que não são apenas documentos e relatório, mas também rotinas processos, práticas e normas organizacionais. Por isso, o conhecimento é resultante da associação dos meios estruturados como livros e documentos, e de contatos pessoais que vão desde conversas informais até relações de aprendizado.

Com isso, segundo Perrotti (2004), "a Gestão do Conhecimento é uma forma de tornar o ambiente favorável para que a organização identifique suas competências, encontre os conhecimentos que ela já possui, aprenda o que precisa, compartilhe e use estes conhecimentos na velocidade necessária ao desenvolvimento dos seus negócios”.

Assumpção (1996) coloca que a formação de um banco de dados na empresa ainda esbarra em dificuldades, que são: a) a conscientização dos envolvidos quanto a importância das informações coletadas e a utilização destas informações; b) alocação de pessoal para a coleta dos dados; c) receio que os dados sejam divulgados para comparação de desempenho com outras empresas; d) a dificuldade de se iniciar o processo de medição; e e) falha no armazenamento de registros, dificultando a coleta de dados históricos.

Com importância igual à qualidade da informação, está a capacidade dos agentes que receberão as informações, os receptores do processo. Souza (2001) destaca que a capacidade do receptor em compreender e aplicar a informação também irá determinar o uso da informação recebida. Ou seja, "a formação é um dos elementos chaves para o progresso do setor da construção civil".

No processo de planejamento operacional, já é intenso o uso da tecnologia da informação como instrumento de gerenciamento. Segundo Davenport (1994), a tecnologia da informação pode ser um instrumento de capacitação, gerenciamento e modificação de seqüências de processos, reduzindo custos e tempos, e auxiliando a análise de informações e tomada de decisões. No entanto, como comentado pelo autor, o investimento em um sistema de informação só é viável após a análise de como a informação está estruturada e interage com os processos da empresa; caso contrário, corre-se o risco de implantar um sistema de informação que não é aderente ao fluxo de informações da empresa, não trazendo os benefícios esperados. 
Contador (1997) aponta as possibilidades que a tecnologia da informação proporciona: a) disponibilização da informação em todos os lugares; b) a possibilidade de um profissional generalista executar o trabalho de um especialista; c) a difusão da autoridade da tomada de decisão (níveis hierárquicos mais baixos podem ter conhecimento da informação e tomar ações para compensar os desvios); d) agilizar o contato com o cliente; e) localização mais rápida da informação; e f) possibilidade de revisão dos modelos em intervalos mais curtos.

No entanto, a tecnologia da informação deve oferecer algo que acrescente valor ao processo. Caso contrário, a ferramenta é dispensável, pois "as pessoas compõem os elementos básicos" do gerenciamento, comenta Contador (1997).

\subsection{GESTÃO DE PESSOAS}

As características da organização da equipe de trabalho, do gestor e o envolvimento dos agentes no processo de planejamento da produção são fundamentais na gestão deste processo. O sistema de planejamento envolve diversas hierarquias da empresa, e dá sustentação a competitividade da empresa no setor. A forma como os agentes interferem no processo, e necessitam da gestão deste processo para a tomada de decisão, caracteriza o desempenho do sistema de planejamento dentro da organização.

A forma de estruturação da empresa com relação a organização das pessoas determinam como uma empresa realmente trabalha, e como seus processos acontecem. De acordo com Vasconcellos e Hemsley (1997), "a sintonia entre fator humano e estrutura é um pré-requisito para o sucesso da organização". Os autores justificam que "uma estrutura organizacional pode ser a mais adequada, tendo-se em vista a natureza da atividade, os objetivos e as características do ambiente externo; entretanto, se esta estrutura é incompatível com o fator humano ${ }^{11}$, sua probabilidade de sucesso será pequena”.

Uma organização não é simplesmente uma associação de pessoas com atribuições de tarefas. Como explica Souza (2001), estas pessoas precisam estar inter-relacionadas e buscar objetivos comuns, que são os objetivos da organização. A autora ainda complementa que "as

\footnotetext{
11 Vasconcellos (1997) define fator humano "como as características dos indivíduos e grupos que formam a organização, assim como o clima organizacional existente”.
} 
boas organizações são aquelas que possuem equipes fortes, formadas por indivíduos engajados e motivados".

Deste modo, o trabalho de coordenação é uma tarefa de base para estruturação da empresa. A tarefa de coordenação integra as atividades, que em um primeiro momento são divididas entre os diversos agentes. Mais do que isso, segundo Souza (2001), a coordenação é uma atividade pró-ativa que deve incentivar os agentes a colaboração e a participação, buscando o envolvimento de todos, como também apontado por Varalla (2003).

Como já mencionado, a motivação dos indivíduos garante a formação das equipes em busca dos objetivos comuns da organização. Como explicado por Vasconcellos e Hemsley (1997), “a motivação mais forte para a atitude de colaboração é o interesse próprio; congregando forças de modo cooperativo, espera-se que os benefícios para cada membro do esforço conjunto sejam bem maiores do que se tivessem atuando individualmente. (...) O outro motivo para a colaboração é a certeza de que levará ao sucesso de empreendimento, beneficiando, deste modo, o grupo ou organização maior, mesmo que a recompensa dos indivíduos, em si, seja pequena".

Calvert, Coles e Bailey (1995) coloca que os planos e a organização podem ser fracassados sem a vontade de cooperação dos agentes; a vontade de fazer o melhor e o entusiasmo pelos objetivos da empresa. Sendo assim, "motivação é essencialmente um processo social, a função executiva de cultivo à moral, inspiração de lealdade aos líderes, e clima emocional e produtivo, conduzindo ao cumprimento dos objetivos determinados ao grupo".

Em um trabalho de equipe, além da motivação, a atribuição de responsabilidades e autoridades estabelece como a equipe é coordenada e como o trabalho é conduzido. A atribuição de responsabilidades e autoridades aos agentes que não interferem na coordenação da equipe, ou seja, indivíduos que não possuem a liderança, pode causar interferências na gestão dos processos.

Responsabilidade, segundo Calvert, Coles e Bailey (1995), é atribuir uma tarefa pela qual se deve prestar retorno a um agente. Este agente ainda deve responder pela maneira de execução da tarefa a ele atribuída. Toda responsabilidade, como ressaltado pelos autores, deve ser correspondente a uma autoridade. Portanto, as funções dos agentes devem ser bem definidas para que não exista um descolamento entre a responsabilidade sobre uma atividade atribuída a um indivíduo, e a respectiva autoridade atribuída a outro envolvido no processo. 
Por isso, Calvert, Coles e Bailey (1995) recomendam que as atividades da organização sejam descritas, alocando aos diversos envolvidos, as responsabilidades e autoridades, de modo a formalizar as relações, e complementar as informações de hierarquia apresentadas pelo organograma da empresa.

Dentro do processo, a figura do líder é que vai influenciar o comportamento dos indivíduos e do grupo, segundo Vasconcellos e Hemsley (1997). O líder deve conhecer todas as especialidades envolvidas no processo, fundamentando sua análise e capacidade de contestamento, orientando a tomada de decisão. Para tanto, segundo Halpin e Woodhead (2004), o líder deve possuir competência em um leque de assuntos qualitativos e quantitativos, e deve ter o pensamento estruturado de um gerente, que observa e analisa o processo como um todo, e a integração no fluxo da organização.

Pasternak (2005) comenta que os gerentes de projeto são cada vez mais necessários, que devem entender e aplicar "métricas de negócio no seu dia-a-dia". O gerente de projeto deve considerar em suas análises desde a taxa de retorno do empreendimento, até a alocação das equipes de produção e logísticas de abastecimento de sua obra. Ou seja, o gerente de projetos precisa ter em mente a gestão de pessoas, a gestão dos custos e da qualidade, com visão global do negócio e não apenas de suas atribuições diretas.

\subsection{COMENTÁRIOS FINAIS DO CAPÍTULO}

A estrutura organizacional da empresa influencia em como o planejamento é estabelecido e implementado nos diversos níveis hierárquicos. Portanto, a forma como a empresa se organiza é fundamental no estabelecimento do sistema de planejamento, bem como na inserção e gestão do processo de planejamento no fluxo de processos principais da empresa.

Para caracterizar o sistema de planejamento de uma organização, é necessário entender como a empresa está organizada e o sistema de decisões decorrente desta estruturação.

A organização da empresa por processos auxilia a visualização de um encadeamento lógico de processos que são orientados pelo produto ou serviço que deve ser entregue ao cliente final. Fazendo parte deste encadeamento lógico está o processo de planejamento da produção, com suas diversas interfaces, caracterizadas pela visão do planejamento como um processo, com suas entradas, operações, saídas e controles. 
A gestão deste processo no contexto da organização garante o cumprimento das funções pelos agentes, o fluxo de informações, o controle do processo, e a tomada de ações globais no ambiente da empresa. Para tanto, informações e equipes precisam ser gerenciadas visando o objetivo comum da organização. 


\section{ESTUDOS DE CASO}

Os estudos de caso foram realizados em três empresas construtoras, denominadas " $A$ ”, " $B$ ” e “C”. Os estudos de caso tiveram como finalidade principal responder a três questões: 1) como está estruturado o processo de planejamento da produção nestas empresas construtoras; b) como é gerenciado o processo de planejamento da produção; e c) como este processo é integrado aos demais processos do fluxo.

Inicialmente, as três empresas são caracterizadas através da apresentação de sua estrutura organizacional, foco de negócio e dados de empreendimentos já realizados e em execução.

Identificando as atividades administrativas, operacionais e gerenciais do processo de planejamento da produção da empresa, é apresentado como o processo é gerenciado e como é promovida a integração com os demais processos do fluxo.

A partir do embasamento teórico e da confrontação da gestão do processo de planejamento da produção teórico e o prático, são apontadas as práticas que já estão sendo aplicadas pelas empresas e que auxiliam a gestão deste processo, bem como as falhas com propostas de ações de melhoria no processo

Os estudos de caso nas três empresas construtoras foram iniciados em junho de 2005 e concluídos em abril de 2006. Para os estudos de caso, foram utilizados questionários com roteiros semi-estruturado de entrevista, contendo os temas-chave para discussão (ver anexo). As entrevistas foram realizadas principalmente com o gerente de planejamento e com o gerente de obra, tendo as informações complementadas por entrevistas a equipe de produção e empresas subcontratadas para a execução planejamento.

\subsection{CARACTERIZAÇÃO DAS EMPRESAS CONSTRUTORAS}

Nesta seção são apresentadas as empresas estudadas e as características organizacionais e modelos de gestão adotados. Os dados das empresas são apresentados na Tabela 3.1, seguido da apresentação dos respectivos organogramas fornecidos pelas empresas nas figuras 3.1, 3.2 e 3.3 . 
Tabela 3.1 - Caracterização das empresas construtoras

\begin{tabular}{|c|c|c|c|}
\hline Características & Empresa A & Empresa B & Empresa C \\
\hline Fundação & Agosto de 1982 & Maio de 1990 & 1985 \\
\hline Ramo de atuação & $\begin{array}{l}\text { Incorporação e } \\
\text { Construção }\end{array}$ & $\begin{array}{l}\text { Incorporação e } \\
\text { Construção }\end{array}$ & $\begin{array}{l}\text { Incorporação e } \\
\text { Construção }\end{array}$ \\
\hline $\begin{array}{l}\text { Região de atuação } \\
\text { principal }\end{array}$ & Estado de São Paulo & Cidade de São Paulo & Cidade de São Paulo \\
\hline $\begin{array}{l}\text { Número de funcionários } \\
\text { próprios }\end{array}$ & 47 & 75 & 60 \\
\hline $\begin{array}{l}\text { Número de funcionários } \\
\text { terceirizados }\end{array}$ & 14 & 0 & 0 \\
\hline $\begin{array}{l}\text { Tipologia das } \\
\text { construções }\end{array}$ & $\begin{array}{l}\text { Obras de incorporação } \\
\text { ou por contrato, } \\
\text { residenciais de médio } \\
\text { e alto padrão, } \\
\text { comerciais e } \\
\text { industriais }\end{array}$ & $\begin{array}{l}\text { Obras de incorporação } \\
\text { ou por contrato, } \\
\text { residenciais de médio } \\
\text { e alto padrão, e } \\
\text { comerciais }\end{array}$ & $\begin{array}{l}\text { Obras de incorporação } \\
\text { ou por contrato, } \\
\text { residenciais de baixo, } \\
\text { médio e alto padrão, e } \\
\text { comerciais }\end{array}$ \\
\hline Obras já executadas & $\begin{array}{l}31 \text { empreendimentos } \\
\text { residenciais de alto } \\
\text { padrão; } 17 \\
\text { empreendimentos } \\
\text { comerciais; } 6 \\
\text { empreendimentos } \\
\text { industriais } \\
\text { (640.000,00 } \mathrm{m}^{2} \mathrm{de} \\
\text { área construída) }\end{array}$ & $\begin{array}{l}10 \text { empreendimentos } \\
\text { residenciais de alto } \\
\text { padrão; } 5 \\
\text { empreendimentos } \\
\text { residenciais de médio } \\
\text { padrão; } 1 \\
\text { empreendimento } \\
\text { comercial } \\
\text { (155.000,00 } \mathrm{m}^{2} \text { de } \\
\text { área construída) }\end{array}$ & $\begin{array}{c}4 \text { empreendimentos } \\
\text { residenciais de alto } \\
\text { padrão; } 15 \\
\text { empreendimentos } \\
\text { residenciais de médio } \\
\text { padrão; } 9 \\
\text { empreendimentos } \\
\text { residenciais de baixo } \\
\text { padrão; } 2 \\
\text { empreendimentos } \\
\text { comerciais } \\
\text { (264.334,42 } \mathrm{m}^{2} \mathrm{de} \\
\text { área construída) }\end{array}$ \\
\hline Obras em execução & $\begin{array}{l}7 \text { empreendimentos } \\
\text { residenciais de alto } \\
\text { padrão; } 1 \\
\text { empreendimento } \\
\text { comercial } \\
\left(320.000,00 \mathrm{~m}^{2} \mathrm{de}\right. \\
\text { área construída) }\end{array}$ & $\begin{array}{l}4 \text { empreendimentos } \\
\text { residenciais de alto } \\
\text { padrão; } 1 \\
\text { empreendimento } \\
\text { residencial de médio } \\
\text { padrão } \\
\text { (45.3330,00 } \mathrm{m}^{2} \mathrm{de} \\
\text { área construída) }\end{array}$ & $\begin{array}{c}3 \text { empreendimentos } \\
\text { residenciais de médio } \\
\text { padrão } \\
\left(50.330,55 \mathrm{~m}^{2} \text { de área }\right. \\
\text { construída) }\end{array}$ \\
\hline $\begin{array}{l}\text { Certificação de sistema } \\
\text { de gestão }\end{array}$ & $\begin{array}{c}\text { Certificação } \\
\text { ISO 9001:2000 }\end{array}$ & $\begin{array}{c}\text { Qualificação PBQP-H } \\
\text { e Certificação ISO } \\
9001: 2000\end{array}$ & $\begin{array}{c}\text { Qualificação PBQP-H } \\
\text { e Certificação ISO } \\
\text { 9001:2000 }\end{array}$ \\
\hline
\end{tabular}




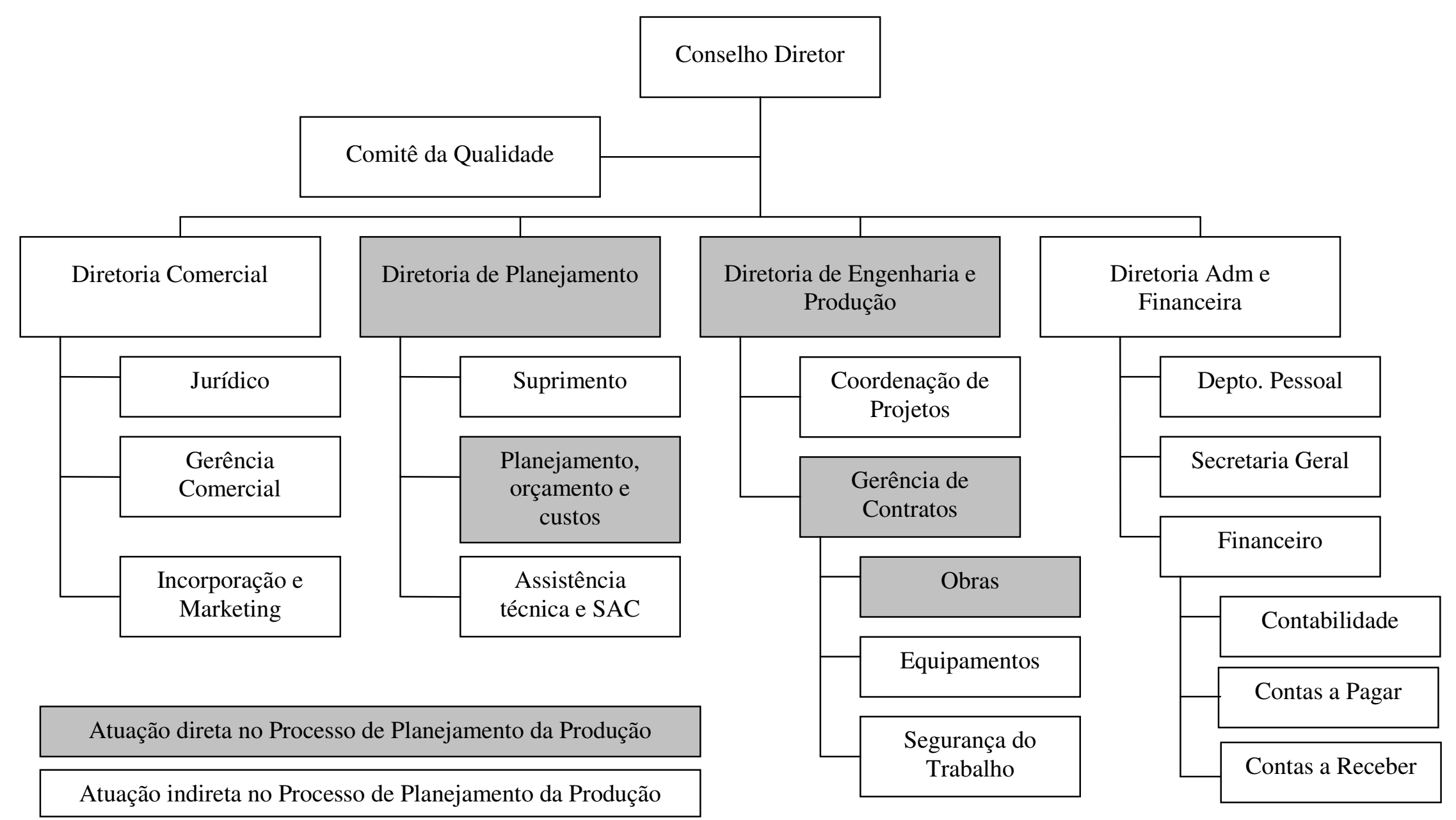

Figura 3.1 - Organograma da empresa A em junho de 2005 


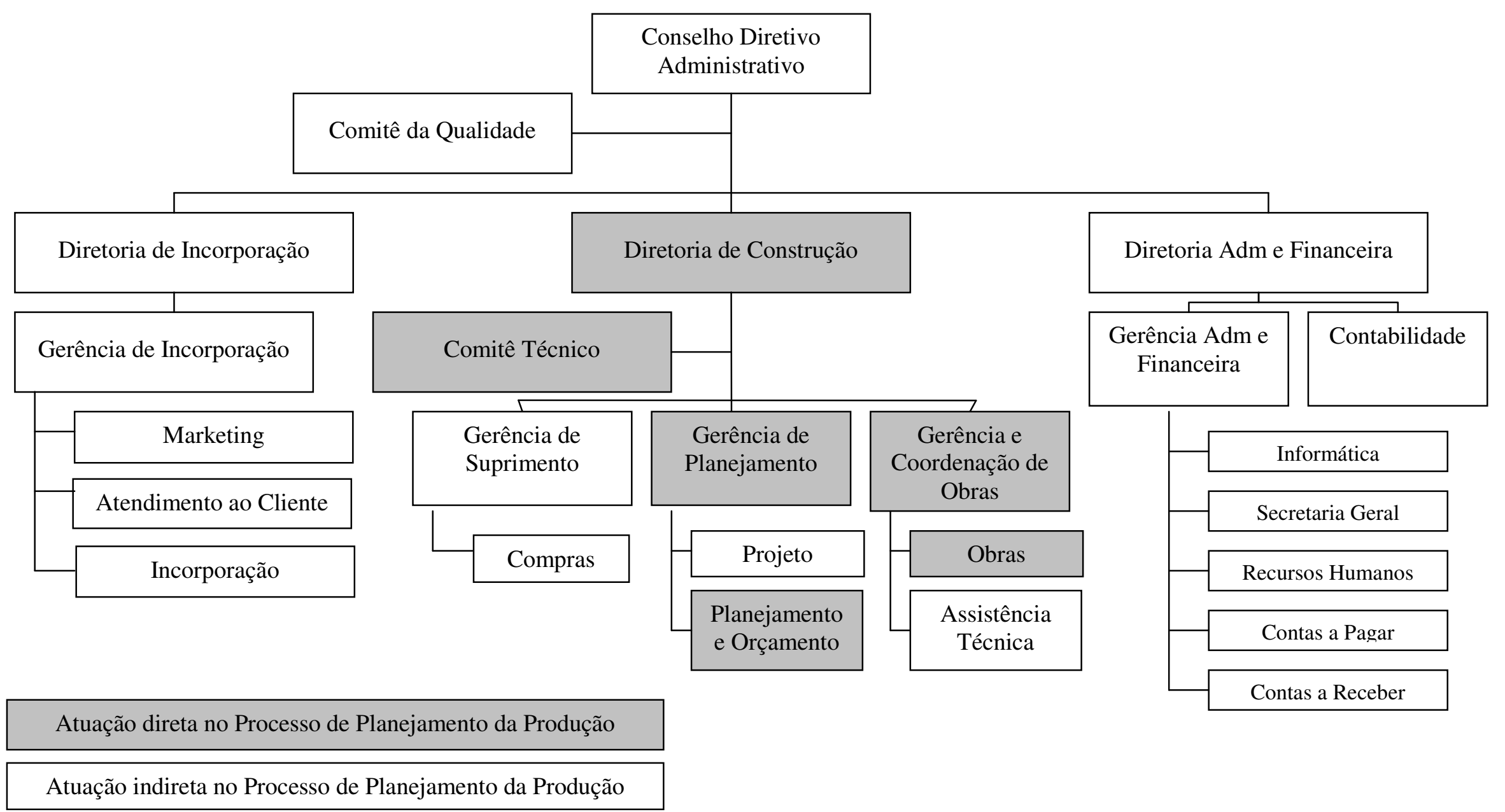

Figura 3.2 - Organograma da empresa B em julho de 2005 


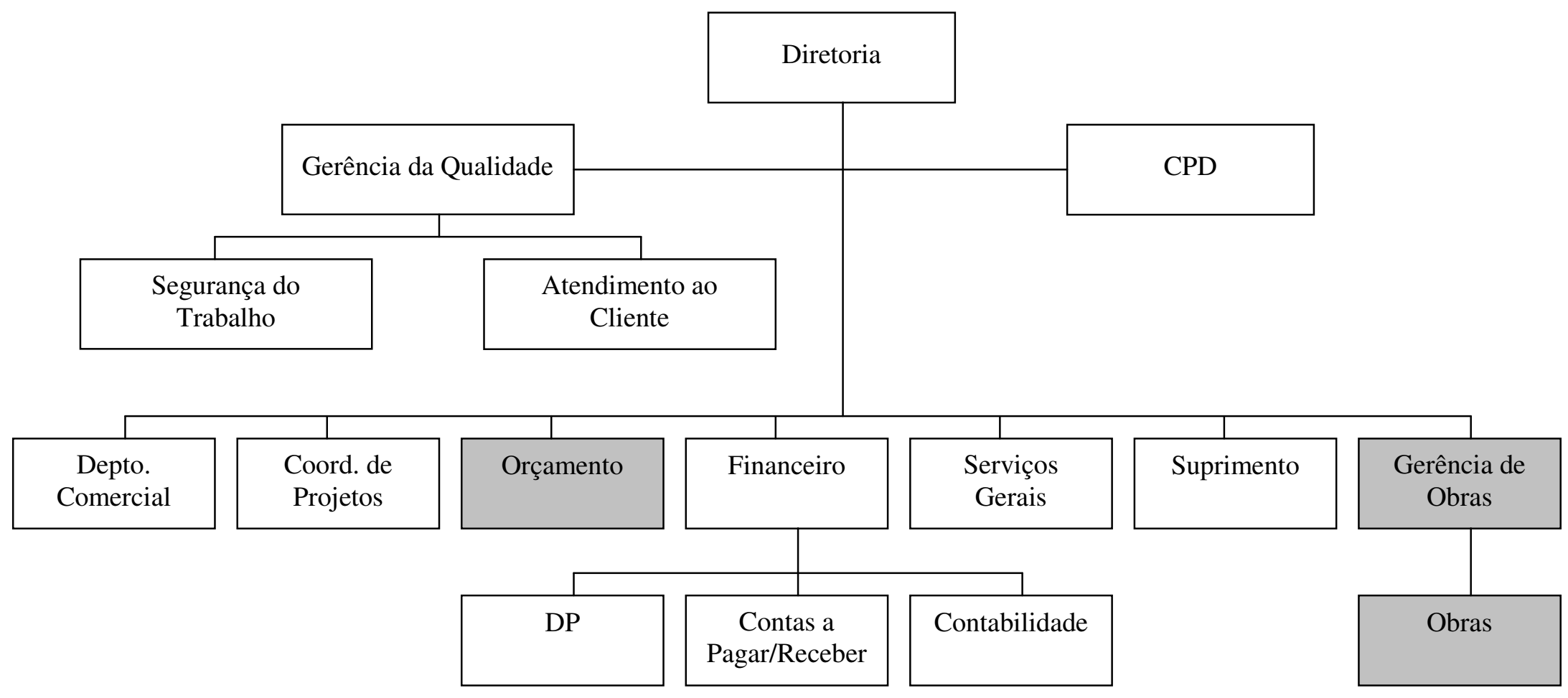

Atuação direta no Processo de Planejamento da Produção

Atuação indireta no Processo de Planejamento da Produção

Figura 3.3 - Organograma da empresa C em abril de 2006 
As três empresas atuam no mercado imobiliário, com foco na incorporação e construção de edifícios residenciais de médio e alto padrão. As empresas possuem sistema de gestão da qualidade, o que é relevante neste trabalho, pois já existe na empresa a preocupação com a padronização das atividades e a visão de processos.

Pelos organogramas, observa-se que as empresas são organizadas por departamentos segundo o critério de funcionalidade. Quanto ao processo de planejamento da produção, as empresas A e B possuem equipe interna com as funções de planejamento da produção, enquanto a empresa $\mathrm{C}$ executa o orçamento internamente mas subcontrata a programação e o controle. A empresa A possui uma diretoria de planejamento; a empresa B possui uma gerência de planejamento subordinada à diretoria de construção; e a empresa $\mathrm{C}$ possui um departamento de orçamento diretamente subordinado à diretoria da empresa e uma gerência de obras também diretamente subordinada à diretoria da empresa.

Também é interessante observar que na empresa A os departamentos de suprimento e assistência técnica são subordinados à diretoria de planejamento; e na empresa B o departamento de projeto é subordinado à gerência de planejamento.

A equipe de planejamento da empresa A é formada pelo Diretor de Planejamento, o Gerente de Planejamento, um Engenheiro de Planejamento, um Engenheiro Civil e um Técnico de Edificações. A função principal do Engenheiro Civil e do Técnico de Edificações é o levantamento de quantitativos e a estruturação de orçamentos. O Engenheiro de Planejamento é um engenheiro civil e é responsável pelo acompanhamento do planejamento nas obras. $\mathrm{O}$ Gerente de Planejamento, também engenheiro civil, é responsável pela gestão do processo de planejamento da produção, que consiste nas atividades de orçamentação, programação e controles físico e custos. A operação da atividade de orçamentação é executada pelo Engenheiro Civil e pelo Técnico de Edificações, com a análise e aprovação do Gerente de Planejamento; já a operação da atividade de programação é realizada pelo próprio Gerente de Planejamento. O Diretor de Planejamento, engenheiro civil, é responsável pela aprovação do planejamento e coordenação com a Diretoria de Engenharia e Produção.

A equipe de planejamento da empresa B é formada pelo Gerente de Planejamento e dois estagiários de engenharia civil. Os estagiários são responsáveis por auxiliar na operação dos orçamentos, com levantamento de quantitativos e estruturação, e acompanhamento do planejamento nas obras. O Gerente de Planejamento, engenheiro civil, é responsável pela gestão do processo de planejamento da produção, com as atividades de orçamentação, 
programação e controles físico e custos, como na empresa A. O Gerente de Planejamento é o responsável pela operação do orçamento e programação. A equipe de planejamento também possui a função de manutenção do sistema de gestão da qualidade da empresa.

A empresa $\mathrm{C}$, como já descrito, não possui equipe interna para a operação da programação e controle do processo de planejamento da produção. A empresa possui um Departamento de Orçamento, que executa o orçamento internamente, formado por um engenheiro civil, que responde diretamente à Diretoria da empresa. A operação da programação e controle é subcontratada à uma empresa especializada, que atua com a equipe técnica nas obras sob a supervisão do Gerente de Obras.

Confirmando as características observadas nestas empresas, Vivancos e Cardoso (2001) concluíram, nos estudos de caso realizados em empresas construtoras de edifícios do Estado de São Paulo, os seguintes aspectos: a) que a maioria das empresas são hierarquizadas, organizadas por departamentos, com ênfase na unidade de comando e na comunicação vertical; b) em um terço das empresas estudadas, foram encontradas estruturas matriciais; c) na grande maioria das empresas, já existe uma preocupação em querer focalizar os processos de produção e os administrativos, que na verdade, são decorrentes da implantação de sistemas de gestão da qualidade; d) os sistemas de gestão da qualidade têm proporcionado um aumento da padronização e uma maior formalização dos processos da empresa, além de uma definição mais clara das responsabilidades e dos controles por parte das pessoas envolvidas.

Nos organogramas apresentados nas figuras 3.1, 3.2 e 3.3 estão identificados os departamentos que possuem atuação direta no processo de planejamento da produção. $\mathrm{Ou}$ seja, estes departamentos possuem responsabilidade direta no processo de planejamento da produção.

Com isso, justifica-se a visão de processo dentro da organização, e que torna possível a integração das equipes dos departamentos na execução de um trabalho comum a todos. Inclusive, na empresa A, departamentos de diretorias diferentes atuam sobre o mesmo processo de planejamento da produção.

De acordo com Souza (1997), uma das formas de gestão de processos das empresas construtoras é pelo conceito de cadeia cliente-fornecedor, tanto entre os processos quanto em consideração ao cliente final. O autor ainda ressalta que este conceito pode ser considerado entre os departamentos da empresa, e também entre as equipes de produção nas obras. 
As três empresas possuem a visão de processo, devido principalmente a adoção do sistema de gestão da qualidade como forma de gestão da organização. Todas as empresas possuem procedimentos que padronizam o processo de planejamento da produção, identificando suas entradas, operações e saídas, bem como os responsáveis pelas atividades. Também possuem o fluxo de processos principais identificado.

\subsection{CARACTERIZAÇÃO DAS OBRAS ANALISADAS}

Nesta seção são apresentadas as obras visitadas para a complementação da caracterização e análise do processo de planejamento da produção. Para cada uma das três empresas, foi analisada uma obra com as características do escopo da pesquisa - construção de edifícios residenciais de médio e alto padrão na RMSP. Na tabela 3.2 são apresentados os dados das obras.

Tabela 3.2 - Caracterização das obras

\begin{tabular}{|c|c|c|c|}
\hline Características & $\begin{array}{c}\text { Empresa A } \\
\text { Obra A }\end{array}$ & $\begin{array}{c}\text { Empresa B } \\
\text { Obra B }\end{array}$ & $\begin{array}{c}\text { Empresa C } \\
\text { Obra C }\end{array}$ \\
\hline $\begin{array}{l}\text { Incorporação e/ou } \\
\text { construção pela empresa }\end{array}$ & Construção & $\begin{array}{l}\text { Incorporaçãa e } \\
\text { construção }\end{array}$ & $\begin{array}{l}\text { Incorporaçãa e } \\
\text { construção }\end{array}$ \\
\hline Tipo e padrão & $\begin{array}{l}\text { Edifício residencial } \\
\text { médio/alto padrão }\end{array}$ & $\begin{array}{l}\text { Edifício residencial } \\
\text { alto padrão }\end{array}$ & $\begin{array}{l}\text { Edifício residencial } \\
\text { médio padrão }\end{array}$ \\
\hline Localização & Lapa - SP & Vila Mariana - SP & Penha - SP \\
\hline Área construída em m² & $58.000 \mathrm{~m}^{2}$ & $10.000 \mathrm{~m}^{2}$ & $13.814,94 \mathrm{~m}^{2}$ \\
\hline Pavimentos e subsolos & $\begin{array}{l}2 \text { torres com } 25 \text { pav } \\
\text { tipo e cobertura } \\
\text { duplex; } 1 \text { subsolo } \\
\text { único; } 4 \text { apart/pav de } \\
4 \text { dorm ( } 2 \text { suítes) }\end{array}$ & $\begin{array}{l}1 \text { torre com } 21 \text { pav } \\
\text { tipo e cobertura } \\
\text { duplex; térreo e } \\
\text { mezanino; } 2 \text { subsolos; } \\
1 \text { apart/pav de } 4 \text { suítes }\end{array}$ & $\begin{array}{l}2 \text { torres com } 15 \text { pav } \\
\text { tipo; } 2 \text { subsolos; } 4 \\
\text { apart/pav de } 3 \text { dorm } \\
\text { (1 suíte) }\end{array}$ \\
\hline Início da construção & Abril/2005 & Julho/2004 & Outubro/2005 \\
\hline Prazo de entrega & Março/2007 & Julho/2006 & Outubro/2006 \\
\hline Fase atual da construção & $\begin{array}{l}\text { estrutura, vedação, } \\
\text { instalações e } \\
\text { revestimento interno }\end{array}$ & acabamentos, pintura & $\begin{array}{l}\text { alvenaria estrutural, } \\
\text { instalações e } \\
\text { revestimento interno }\end{array}$ \\
\hline
\end{tabular}


Tabela 3.2 - Caracterização das obras (continuação)

\begin{tabular}{|l|c|c|c|}
\hline \hline Características & $\begin{array}{c}\text { Empresa A } \\
\text { Obra A }\end{array}$ & $\begin{array}{c}\text { Empresa B } \\
\text { Obra B }\end{array}$ & $\begin{array}{c}\text { Empresa C } \\
\text { Obra C }\end{array}$ \\
\hline Número de funcionários & $\begin{array}{c}220 \text { funcionários } \\
\text { próprios e } 80 \\
\text { subempreitados }\end{array}$ & $\begin{array}{c}7 \text { funcionários } \\
\text { próprios e 70 } \\
\text { subempreitados }\end{array}$ & $\begin{array}{c}\text { 5 funcionários } \\
\text { próprios e 95 } \\
\text { subempreitados }\end{array}$ \\
\hline $\begin{array}{l}\text { Serviços mão-de-obra } \\
\text { própria }\end{array}$ & $\begin{array}{c}\text { estrutura, vedação, } \\
\text { revestimentos internos } \\
\text { e externo }\end{array}$ & nenhum & nenhum \\
\hline $\begin{array}{l}\text { Modificação do } \\
\text { apartamento pelo cliente }\end{array}$ & Aceita & Aceita & Não aceita \\
\hline \hline
\end{tabular}

Também são apresentados os organogramas das obras nas figuras 3.4, 3.5 e 3.6.

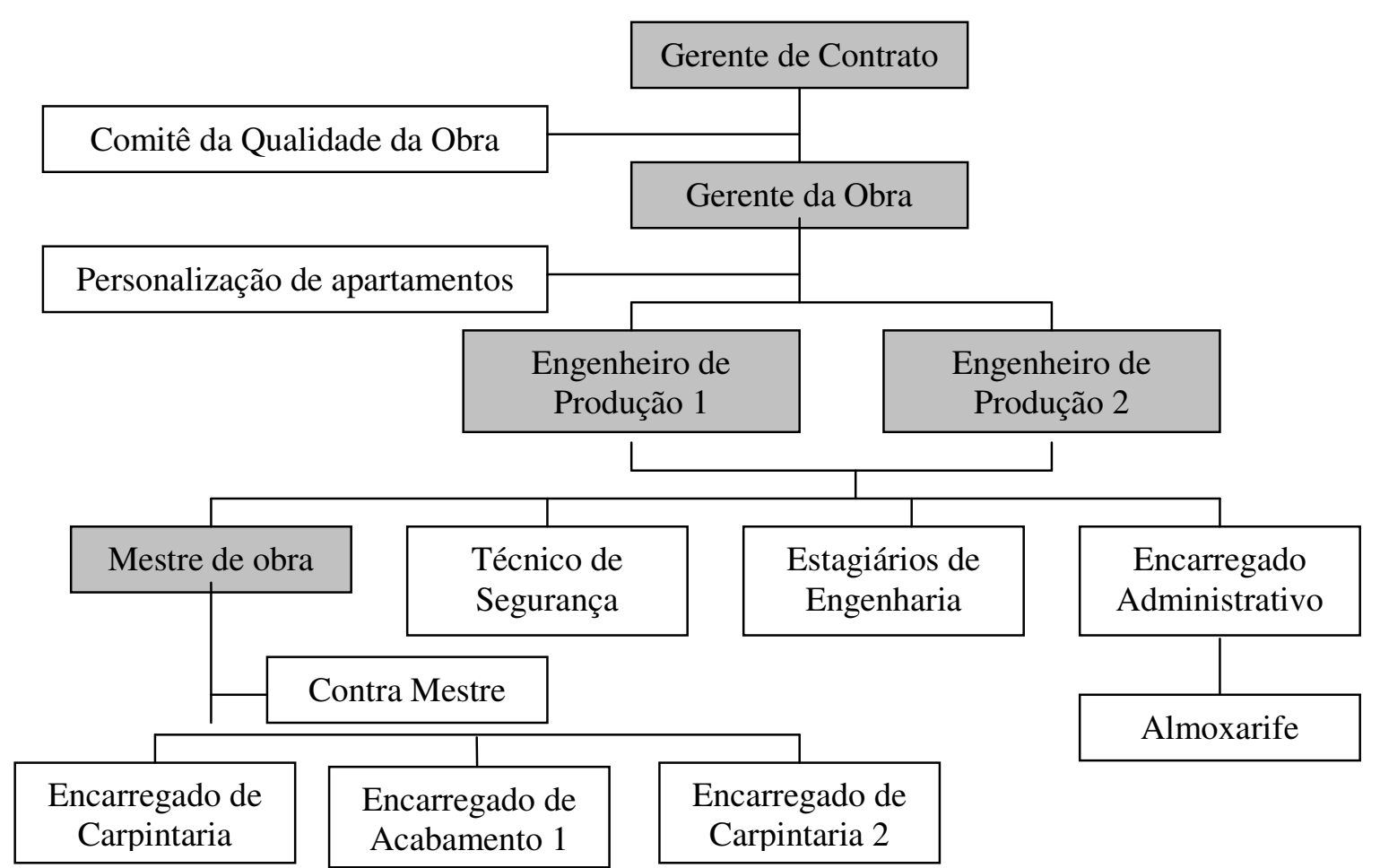

Atuação direta no Processo de Planejamento da Produção

Atuação indireta no Processo de Planejamento da Produção

Figura 3.4 - Organograma da obra A em abril de 2006 


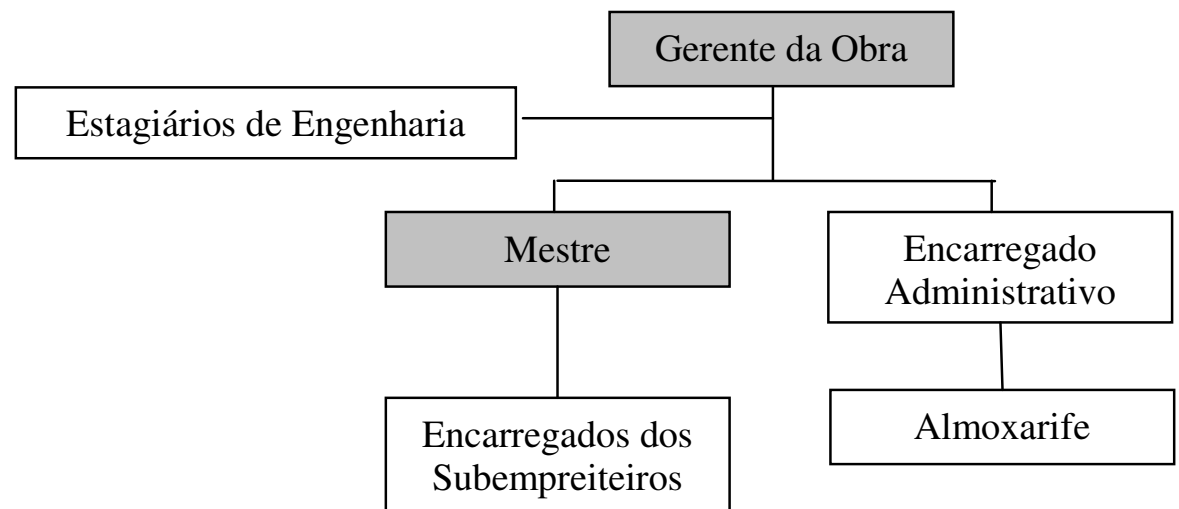

Atuação direta no Processo de Planejamento da Produção

Atuação indireta no Processo de Planejamento da Produção

Figura 3.5 - Organograma da obra B em abril de 2006

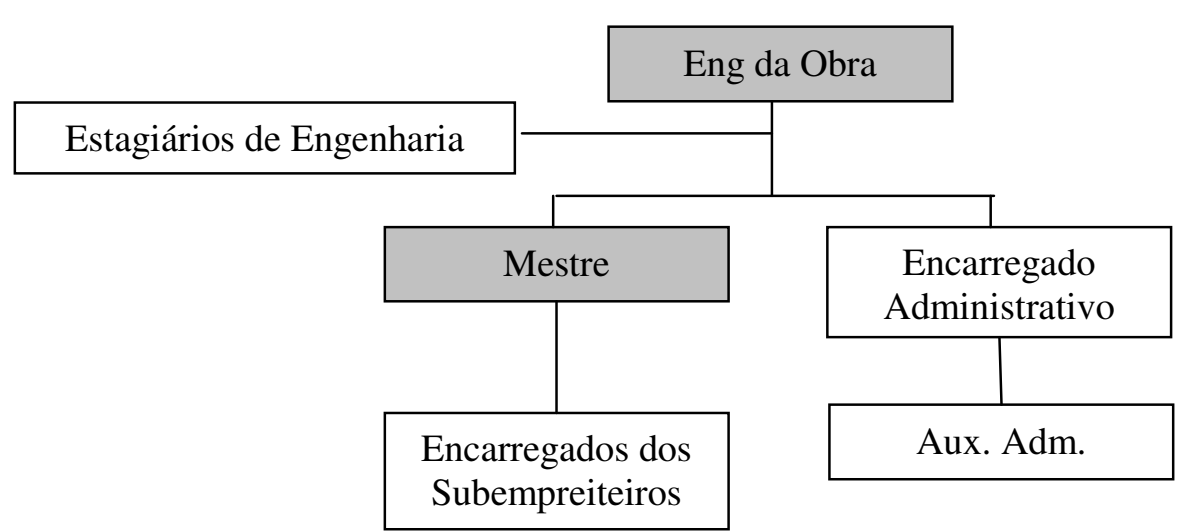

Atuação direta no Processo de Planejamento da Produção

Atuação indireta no Processo de Planejamento da Produção

Figura 3.6 - Organograma da obra C em abril de 2006

As obras A e B possuem características mais semelhantes: ambas são de alto padrão, aceitam modificações de vedação e acabamentos pelo cliente, e prazo de obra mais estendido (aproximadamente dois anos de duração). Já a obra C é um empreendimento de médio padrão, sistema construtivo de alvenaria estrutural e não são aceitas modificações pelo cliente, com o prazo de obra de um ano. 
A estrutura administrativa da obra A é maior, se comparada com as estruturas das obras B e $\mathrm{C}$, devido principalmente ao volume de obra $\left(58.000 \mathrm{~m}^{2}\right)$. Além disso, a obra A utiliza mãode-obra própria para a maioria dos serviços de obras civis, subempreitando os serviços especializados como pintura e impermeabilização. Já as obras B e C subempreitam todos os serviços de obra.

Nos organogramas das obras também foram identificadas as funções que possuem atuação direta no processo de planejamento da produção, ou seja, estas funções possuem responsabilidades definidas formal ou informalmente no processo de planejamento da produção.

Na obra A, o Gerente de Contrato e o Gerente da Obra são responsáveis pelo recebimento do caderno de obras com toda a documentação da programação física e financeira, e dos controles. O Gerente da Obra deve analisar a documentação recebida e aprovar a programação, ou solicitar ajustes ou detalhamentos. A partir da aceitação da documentação, o Gerente da Obra é responsável pelo cumprimento das metas, e pela elaboração das programações de médio e curto prazo, que são comunicadas aos Engenheiros de Produção, Mestre e Encarregados. Os Engenheiros de Produção, Mestre e Encarregados são os responsáveis pela comunicação das metas às equipes de produção. O Gerente da Obra também é responsável pelo acompanhamento dos serviços, efetuando os controles de progresso físico e de custos, informando ao Gerente de Planejamento o resultado mensal.

Como nesta obra a maioria dos serviços são realizados por mão-de-obra própria, o Gerente da Obra é responsável pelo dimensionamento das equipes e alocação dos recursos. A operação desta programação de médio e curto prazo é discutida no item 3.3.1.

Na obra B, o Gerente da Obra é responsável pela análise e aprovação do caderno de obras, que possui a documentação do orçamento da obra, programação física, programação de empenho (custos), critérios de medição e cronograma de suprimento. Sendo o caderno aprovado, o Gerente da Obra é responsável pela elaboração das programações de médio e curto prazo, e a comunicação das metas ao Mestre da Obra e Subempreiteiros. O Mestre da Obra é responsável pelo monitoramento das metas das equipes de produção subempreitadas. Como na empresa A, o Gerente da Obra também é responsável pelo acompanhamento dos serviços através dos controles de progresso físico e de custos, que devem ser transmitidos ao Gerente de Planejamento. 
Na obra C, o Engenheiro da Obra é responsável pela aprovação da programação física de longo, médio e curto prazo elaborada pela empresa subcontratada abrangendo os serviços da torre; e pela elaboração da programação dos serviços de periferia. As metas de produção são comunicadas pela empresa subcontratada ao Mestre e subempreiteiros, e estes são responsáveis pela comunicação às equipes de produção. A empresa subcontratada realiza o acompanhamento do progresso físico, e o Engenheiro da Obra é responsável pelo controle dos custos.

As três obras estudadas possuem características que exigem funções diferentes do processo de planejamento da produção. A obra A, por trabalhar com mão-de-obra própria, demanda da programação um estudo mais detalhado da alocação de equipes e produtividade. Isto não significa que em obras que utilizam subempreiteiros esta também não seja uma necessidade. No entanto, em uma obra com o volume de serviços como o da obra A e com a mão-de-obra tendo que ser apropriada pelo Gerente da Obra, o estudo detalhado da alocação das equipes é uma das funções mais importantes que deve ser suprida pelo planejamento.

Já a obra B possui como característica crítica a interferência direta dos clientes e a execução dos acabamentos. Por ser um edifício de alto padrão com poucas unidades, o cliente acaba tendo um contato maior com a obra, e a abertura na aceitação de modificações das unidades também é maior. Com isso, uma das principais necessidades que o planejamento deve atender é a simulação de cenários com as interferências e os limites aceitáveis.

A obra $\mathrm{C}$ é um empreendimento de médio padrão que utiliza o sistema construtivo de alvenaria estrutural. Portanto, a repetição é uma característica da construção, que deve ser bem estudada pela programação para melhorar a racionalização dos processos e aspectos de logística. Com isso, uma das principais funções do planejamento é racionalizar a utilização de recursos - material, mão-de-obra e equipamentos.

\subsection{O PROCESSO DE PLANEJAMENTO DA PRODUÇÃO NAS EMPRESAS CONSTRUTORAS}

Com as informações obtidas nas entrevistas realizadas nos escritórios com os responsáveis pelo processo de planejamento da produção das empresas construtoras A, B e C, em uma das obras das empresas, denominadas também A, B e C respectivamente, com os gerentes das obras, e com os responsáveis pelas equipes de produção - os mestres de obras - foi possível 
identificar as atividades administrativas, operacionais e gerenciais do processo de planejamento da produção nestas empresas. Na empresa $\mathrm{C}$, as informações também foram complementadas pela empresa subcontratada para a operação da programação e controle. Com isso, são descritos os processos de planejamento da produção nas três empresas estudadas.

\subsubsection{O processo de planejamento da produção na empresa A}

Na figura 3.7 é ilustrado o processo de planejamento da produção na empresa A, e em seguida são descritos as entradas, os recursos, a operação, o controle e as saídas do processo.

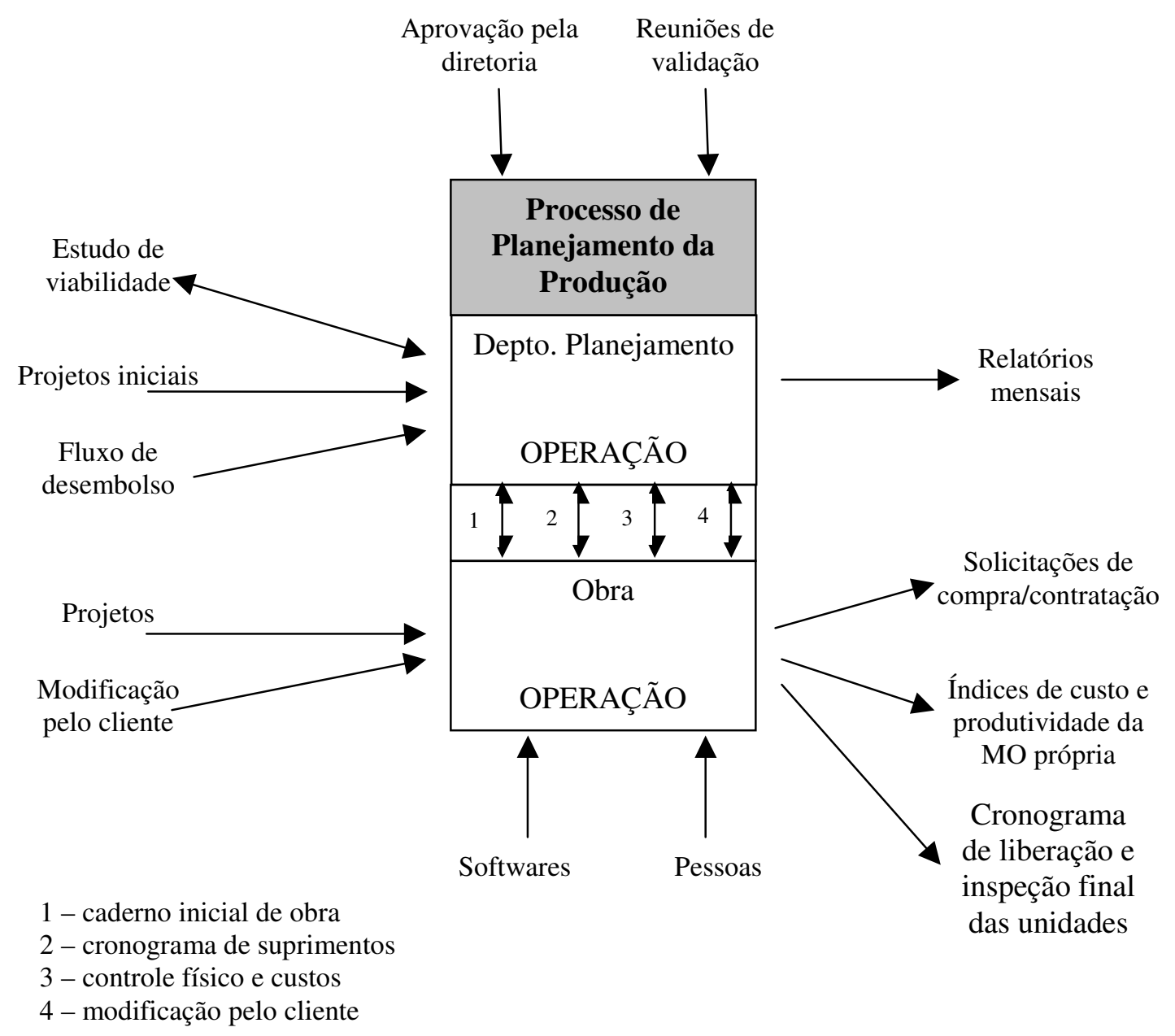

Figura 3.7 - Processo de planejamento da produção da empresa A 


\section{1) Entradas do processo}

O processo de planejamento da produção começa a atuar em um empreendimento ainda na fase de estudo de viabilidade (obras de incorporação) e participação em concorrências (obras por contrato). O processo comercial encaminha para o processo de planejamento da produção os dados do empreendimento como memorial descritivo, projetos e edital de concorrência. $\mathrm{O}$ grau de detalhamento da documentação recebida pode variar bastante, principalmente em obras por contrato, que geralmente encaminham projetos básicos ou de prefeitura. Também não existe uma padronização e formalização na entrega desta documentação tanto em obras incorporadas pela empresa quanto por contrato.

Nas obras incorporadas, existe a preocupação com o detalhamento das informações encaminhadas ao processo de planejamento. Os projetos geralmente já são executivos e o memorial descritivo já define com detalhes os sistemas construtivos e acabamentos.

O processo comercial também entrega ao processo de planejamento da produção a equação de fundos do empreendimento, ou fluxo de desembolso, no nível macro dos pacotes de trabalho, que define principalmente prazos da obra e fluxo de caixa.

As diretrizes de produção do empreendimento são definidas em reunião com Diretoria Comercial, Diretoria de Planejamento e Diretoria de Engenharia e Produção. Nesta reunião são definidas as estratégias macro de produção, logística e tecnologia.

$\mathrm{Na}$ segunda etapa do processo de planejamento da produção, quando o empreendimento já está em construção, os projetos executivos e projetos para produção são recebidos diretamente pela obra, encaminhados pelo Departamento de Coordenação de Projetos subordinado à Diretoria de Engenharia e Produção. Na obra estudada, são elaborados projetos para produção de fôrma e alvenaria.

As solicitações de modificação dos apartamentos pelos clientes também são recebidas pela obra. Uma arquiteta que faz parte da equipe administrativa da obra é responsável pelo recebimento das solicitações e aprovação com os clientes. 


\section{2) Recursos do processo}

O Departamento de Planejamento, Orçamento e Custos é formado por um Gerente de Planejamento, um Engenheiro de Planejamento, um Engenheiro Civil e um Técnico de Edificações. Este departamento é subordinado ao Diretor de Planejamento.

Como já descrito na seção 3.1, o Engenheiro Civil e o Técnico de Edificações atuam na elaboração dos orçamentos, o Engenheiro de Planejamento acompanha o planejamento nas obras e o Gerente de Planejamento analisa e aprova os orçamentos, e operacionaliza a programação e controle das obras. O Diretor de Planejamento aprova o planejamento e coordena a interface com a Diretoria de Engenharia e Produção

Este departamento é responsável pelo planejamento da produção das obras da empresa na fase de estudo de viabilidade e concorrências, e após a viabilização do empreendimento, na construção.

Também é responsável pelo acompanhamento do progresso físico das obras, realizando o sistema de controle. Esta função foi assumida pelo departamento no ano de 2005, com a criação da função do Engenheiro de Planejamento. Anteriormente, esta função era responsabilidade do Gerente da Obra, que deveria fornecer as informações para o departamento retroalimentar o sistema de controle e emitir os relatórios gerenciais. Como a empresa detectou falhas nesta sistemática do processo, foi inserida a função do Engenheiro de Planejamento, que passou a assumir a responsabilidade de coletar as informações na obra.

Na obra, o Gerente de Contrato, o Gerente da Obra, os Engenheiros de Produção, Mestres e Encarregados também são recursos do processo de planejamento da produção. As respectivas funções e responsabilidades foram descritas na seção 3.2.

Na elaboração dos modelos da programação, são utilizados os softwares MS Project ${ }^{12}$ e o pacote Office, ambos do ambiente windows.

A empresa também trabalha com a ferramenta Sienge (Sistema Integrado de Engenharia) ${ }^{13}$, com os módulos de orçamento, suprimento e custos.

\footnotetext{
12 Software da classe de gerenciadores de projeto, desenvolvido pela Microsoft Corporation. Este software utiliza a técnica CPM de programação de atividades e alocação dos recursos.

${ }^{13}$ Software de gestão desenvolvido pela empresa Softplan
} 


\section{3) Operação do processo}

$\mathrm{Na}$ fase de estudo de viabilidade e concorrências, é elaborado o orçamento preliminar pelo Departamento de Planejamento, Orçamento e Custos. Este orçamento é elaborado no sistema Sienge, através do levantamento de quantitativos e apropriação de custos estimados, sendo os custos estimados obtidos do banco de dados do Sienge.

Ainda na fase de estudo de viabilidade são elaborados os modelos em cronograma de barras, utilizando o software MS Project, com uma estrutura de WBS bastante detalhada. Nas situações onde os dados de entrada possuem pouco detalhamento do escopo de trabalho, são assumidas algumas premissas no modelo, que deverão ser validadas posteriormente. Um exemplo dado pelo entrevistado é quando o modelo tem que ser elaborado sobre projetos de prefeitura que ainda não possuem análise de interferência de sistemas como instalações, por exemplo. O planejador tem que conseguir visualizar o produto para identificar eventuais interferências para, por exemplo, prever a instalação de forros ou sancas de gesso. Estas premissas precisam ser validadas posteriormente a execução dos projetos executivos, e análise pelo Gerente da Obra. No entanto, estas premissas são registradas apenas na estrutura do WBS da programação ou no sequenciamento das atividades, não havendo um documento que formalize a adoção das premissas ou a posterior validação.

Mesmo com o detalhamento, a programação pode ser considerada como de longo prazo, pois não faz o estudo da alocação da mão-de-obra, que é crítica na empresa A por esta trabalhar com mão-de-obra própria, como já mencionado anteriormente. Além disso, o modelo é elaborado com base na experiência do planejador, pois a empresa não possui um banco de dados de produtividade para a estimativa de durações. Como explicado pelo entrevistado, algumas durações e seqüências são definidas com consulta a fornecedores, como por exemplo no caso das atividades de fundação.

No início da construção, o modelo é avaliado pelo Gerente de Planejamento com o Gerente da Obra, e caso seja necessário, são feitas correções ou alteração. O modelo sendo aprovado, o Gerente de Planejamento elabora o Caderno da Obra, com o orçamento e programação física de longo prazo. Também pode fazer parte deste caderno o fluxo de desembolso da construção. Não há uma ferramenta formal para verificação do atendimento aos requisitos previamente estabelecidos no processo comercial.

O Gerente de Planejamento também lança a programação física no Sienge, com algumas adaptações, para elaborar o cronograma financeiro. Esta entrada de dados no sistema é manual 
pois o sistema não possui a mesma estrutura da ferramenta utilizada na programação. Uma das dificuldades, segundo o entrevistado, é que a programação é bastante detalhada, chegando a ter na maioria das situações, mais de mil itens, e que não necessariamente estão agrupados na mesma estrutura dos centros de custos do sistema, que é a estrutura do orçamento, o que dificulta a comunicação direta entre as duas ferramentas. Também segundo o entrevistado, as funções das saídas das duas ferramentas são diferentes: a programação física tem por finalidade auxiliar o gerenciamento da construção, e o sistema integrado auxilia no controle dos custos e nas compras e contratações.

Após a elaboração do cronograma financeiro no Sienge, este sistema gera o cronograma de suprimento, que também será utilizado pela obra. Na integração do processo de suprimento e processo de planejamento da produção, o sistema atua no controle de custos. O orçamento elaborado no sistema define o custo dos recursos, e dos grupos de atividades, ou centros de custo. As solicitações de compra e contratação são emitidas no sistema e devem ser apropriadas nos centros de custo, e somente são aprovadas se os insumos estiverem previstos e dentro do custo estimado.

Com base na programação de longo prazo, o Gerente da Obra desdobra as tarefas e atividades em programações de médio e curto prazo. O Gerente da Obra elabora uma programação mensal com base na programação de longo prazo e nas metas do fluxo de desembolso, garantindo assim o atendimento à meta de medição física e financeira. Não existe um padrão da empresa para a elaboração desta programação de médio prazo, ficando sob a responsabilidade do Gerente da Obra a decisão de fazer ou não tal desdobramento, e de como fazer. Na obra visitada, o Gerente da Obra monta uma planilha com o horizonte de dois meses para esta análise, com as atividades atrasadas, as previstas para o período e o prazo para realização, que é transmitida aos Engenheiros de Produção e Mestre da Obra em reuniões mensais, na primeira semana do mês.

O Gerente da Obra também elabora uma programação de curto prazo, com o horizonte de uma semana. Esta programação também não é padronizada na empresa. Na obra visitada, o Gerente da Obra elaborou uma planilha onde são marcadas as atividades previstas na semana separadas nos andares e ambientes, com uma coluna de previsto e realizado. Esta planilha é discutida nas reuniões semanais com os Engenheiros de Produção, Mestre e Encarregados. 
Nestas reuniões são discutidos as metas e os desvios. Não há um padrão na empresa para o registro dos desvios do planejamento. Na obra visitada, o Gerente da Obra registra as justificativas dos desvios e compromissos assumidos de recuperação nos diários de obra.

No dimensionamento da mão-de-obra própria, o Gerente da Obra define, com base nas metas de médio e curto prazo, a equipe dos serviços. Os índices de produtividade utilizados neste dimensionamento são baseados nos custos de mão-de-obra do histórico da empresa. Portanto, é utilizado um índice de produtividade médio e o desempenho da equipe é monitorado para verificar se está atendendo a produtividade necessária da equipe, sem avaliação individual. Caso seja necessário, a equipe é aumentada ou reduzida. No entanto, não há uma análise por tarefa.

Para a solicitação de materiais, equipamentos e contratações, o Gerente da Obra deve encaminhar solicitação para o Departamento de Suprimento pelo Sienge, que analisa o escopo da solicitação, negocia e efetua a compra ou contratação. Para auxiliar na organização da obra, o Departamento de Planejamento elabora um cronograma de suprimento com horizonte de quatro meses, em planilha de Excel. Este cronograma é discutido e entregue ao Gerente da Obra em reuniões mensais que participam o Gerente de Planejamento, o Gerente da Obra e o Gerente de Suprimento. Cabe ressaltar que o Gerente de Suprimento não possui a programação da obra, prejudicando a análise e definição dos escopos de contratação. Ou seja, caso o Gerente da Obra não especifique claramente na solicitação de compra e contratação o escopo solicitado, podem ocorrer falhas nos fechamentos dos contratos.

$\mathrm{Na}$ obra, o acompanhamento do progresso físico é feito em gráficos esquemáticos do prédio que indicam com a pintura do pavimento a conclusão do serviço. Este também não é um controle padrão da empresa, mas que a obra utiliza para auxiliar nas medições dos serviços.

Mensalmente, o Gerente da Obra deve encaminhar ao Gerente de Planejamento a medição física da obra. Esta medição é feita em planilhas de Excel que indicam a porcentagem executada dos serviços. A medição do progresso físico mensal também é feita pelo Engenheiro de Planejamento.

Estes dados são encaminhados ao Gerente de Planejamento que elabora o relatório mensal com a situação do progresso físico da obra e a situação do progresso financeiro com os dados do Sienge. O progresso físico é avaliado pela análise da curva "S", e o progresso financeiro é avaliado pela análise dos custos incorridos comparados com o progresso físico dos serviços. 
Este relatório mensal está em fase de implantação na empresa. Anteriormente, os relatórios tinham uma periodicidade trimestral, mas que foi avaliada pela empresa como sendo um período muito longo para a tomada de ações.

Os relatórios são analisados em reuniões do Departamento de Planejamento e Gerente da Obra. Somente em casos de grandes desvios ou de interferências significativas não previstas, é que a programação de longo prazo é revisada. Caso contrário, o Gerente de Obra deve tomar ações no médio e curto prazo, como aumento da equipe ou mudança de sequiência.

Também faz parte da operação do processo de planejamento da produção a elaboração dos orçamentos das solicitações de modificação pelos clientes, recebidas pela Arquiteta residente na obra. Quando as modificações são aprovadas, cabe ao Gerente da Obra a programação e controle da execução das modificações. Com isso, o Gerente da Obra gerencia estas modificações nas programações de médio e curto prazo.

Interferências de projetos não identificadas pela Coordenação de Projetos, bem como revisões, também são gerenciadas pelo Gerente da Obra nas programações de médio e curto prazo. Cabe ressaltar que na fase de construção os projetos são encaminhados pela Coordenação de Projetos diretamente à obra, sem a análise do Gerente de Planejamento.

No término da construção, com a finalidade de orientar o Departamento de Assistência Técnica, o Gerente da Obra deve elaborar uma programação de liberação das unidades para a inspeção final e entrega. No entanto, já na programação de longo prazo da obra visitada, é previsto um período de dois meses para a inspeção final, limpeza e reparos.

Os indicadores de custos são apropriados no sistema Sienge. Os indicadores de custo de mãode-obra balizam a alocação das equipes nas obras.

\section{4) Controle do processo}

A programação de longo prazo e o fluxo de desembolso devem ser aprovados pela Diretoria, pelo Gerente de Contrato e pelo Gerente da Obra.

\section{5) Saídas do processo}

As saídas do processo são os relatórios mensais e os indicadores de custo, já discutidos na operação. 
Também são saídas as solicitações de compra e contratação que são resultado das necessidades de recursos da programação, mas que são negociadas pelo Processo de Suprimento.

O cronograma de liberação das unidades para inspeção final e entrega também é uma saída do processo, sendo informação que será utilizada pelo Processo de Entrega de Obra e Assistência Técnica.

\subsubsection{O processo de planejamento da produção na empresa $B$}

Na figura 3.8 é ilustrado o processo de planejamento da produção na empresa B e em seguida são descritos as entradas, os recursos, a operação, o controle e as saídas do processo.

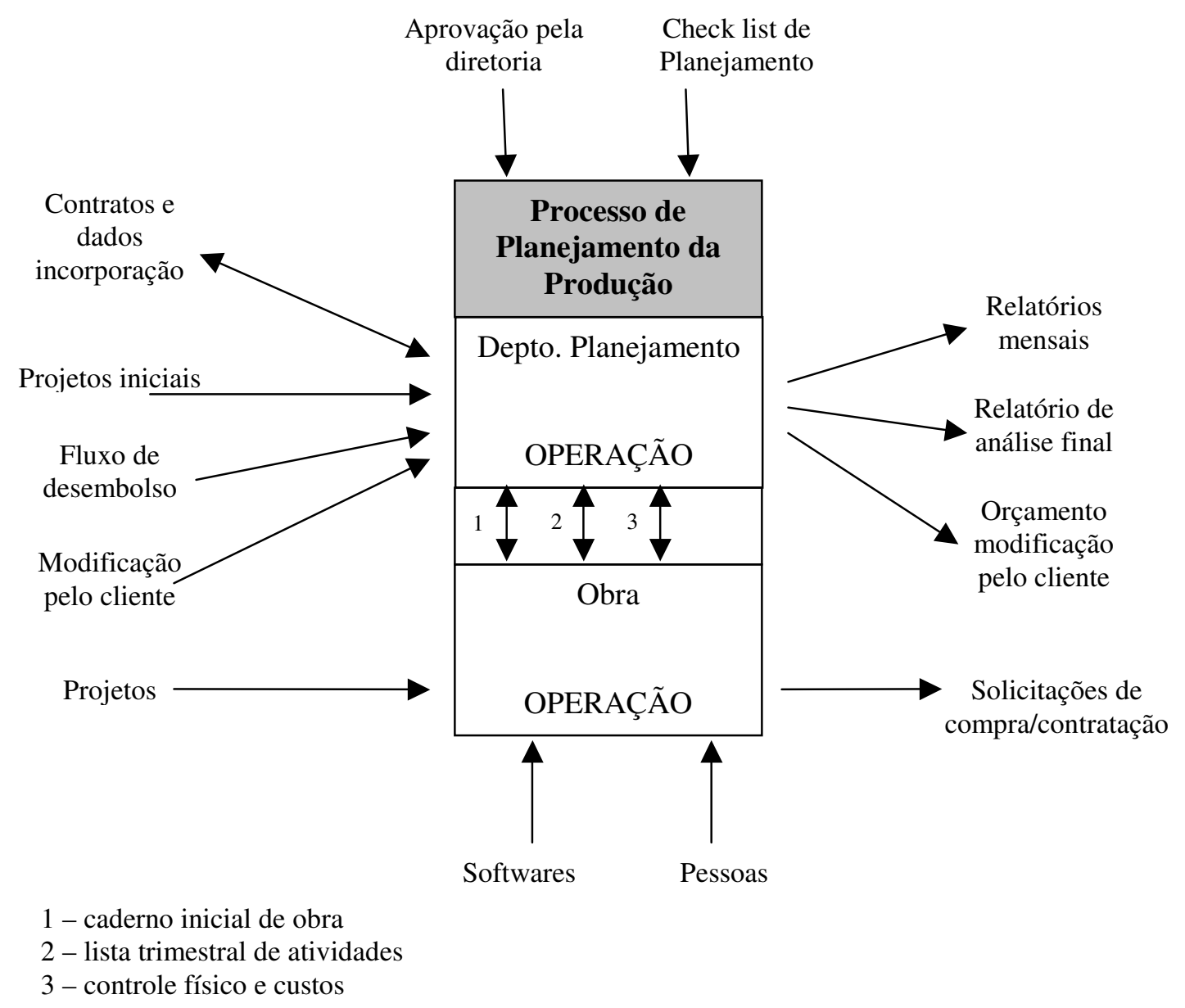

Figura 3.8 - Processo de planejamento da produção da empresa B 


\section{1) Entradas do processo}

Na empresa B, o início do processo de planejamento da produção é semelhante ao da empresa A. Ainda na fase de estudo de viabilidade (obras de incorporação) e participação em concorrências (obras por contrato), o processo comercial encaminha para o processo de planejamento da produção os dados do empreendimento como memorial descritivo, projetos e edital de concorrência. Como na empresa A, o grau de detalhamento da documentação recebida pode variar bastante, principalmente em obras por contrato, que geralmente encaminham projetos básicos ou de prefeitura. Mas nas obras incorporadas, os projetos geralmente já são executivos e o memorial descritivo já define com detalhes os sistemas construtivos e acabamentos.

Também como na empresa A, o processo comercial entrega ao processo de planejamento da produção a equação de fundos do empreendimento, ou fluxo de desembolso aprovado, no nível macro dos pacotes de trabalho, que define principalmente prazos da obra e fluxo de caixa.

As solicitações de modificação dos apartamentos pelos clientes são recebidas pelo processo de entrega de obra e assistência técnica, sendo a função desempenhada pelo Departamento de Atendimento ao Cliente, subordinado à Gerência de Incorporação. Este processo encaminha a solicitação ao processo de planejamento da produção para orçamento da modificação.

Quanto à interface com o processo de projeto, como na empresa $\mathrm{A}$, na empresa $\mathrm{B}$ na segunda etapa do processo de planejamento da produção, quando o empreendimento já está em construção, os projetos executivos e projetos para produção são recebidos diretamente pela obra, encaminhados pelo Departamento de Projetos. Na obra estudada, são elaborados projetos para produção de estrutura, alvenaria e fachada.

\section{2) Recursos do processo}

O Departamento de Planejamento e Orçamento é formado por um Gerente de Planejamento e dois estagiários. Este departamento é subordinado à Diretoria de Construção.

Como já descrito na seção 3.1, os estagiários são responsáveis por auxiliar na operação dos orçamentos e acompanhamento do planejamento nas obras. O Gerente de Planejamento é o 
responsável pela operação do orçamento e programação. A equipe de planejamento também possui a função de manutenção do sistema de gestão da qualidade da empresa.

Como na empresa A, este departamento é responsável pelo planejamento da produção das obras da empresa na fase de estudo de viabilidade e concorrências, e após a viabilização do empreendimento, na construção.

Na obra, o Gerente da Obra, Mestres e Encarregados também são recursos do processo de planejamento da produção. As respectivas funções e responsabilidades foram descritas na seção 3.2 .

Também como na empresa A, na elaboração dos modelos da programação, são utilizados os softwares MS Project e o pacote Office.

Como ferramenta de integração dos processos, a empresa desenvolveu um sistema informatizado para uso interno com as interfaces de orçamento, suprimento e custos. Este sistema opera na intranet da empresa, integrando as atividades desenvolvidas no escritório e nas obras.

\section{3) Operação do processo}

$\mathrm{Na}$ fase de estudo de viabilidade e concorrências, é elaborado o orçamento preliminar. Este orçamento é elaborado através do levantamento de quantitativos e apropriação de custos estimados, sendo os custos estimados obtidos do banco de dados do sistema da empresa.

Após a aprovação do empreendimento e antes do início da construção é elaborado o modelo em cronograma de barras, utilizando o software MS Project. A estrutura de WBS é definida tomando-se como base uma estrutura modelo da empresa, que também é a que define a planilha de medição de obra, e inclui compras, contratações e treinamentos. Após a conclusão da elaboração do modelo do progresso físico no MS Project, são apropriados os custos às atividades seguindo os critérios do orçamento. O MS Project apropria no tempo os custos das atividades e este cronograma, chamado pela empresa de cronograma de empenho, é transferido para o Excel para a formatação do cronograma financeiro, ou fluxo de desembolso. A programação de longo prazo e o fluxo de desembolso são analisados em reunião com o Gerente de Obra, o Gerente de Planejamento e Diretoria de Construção. Nesta reunião é 
verificada a necessidade de correções ou alterações para a aprovação do planejamento da produção, que será considerado como a referência para avaliação da obra.

O Gerente de Planejamento elabora o Caderno da Obra com o orçamento da obra, memorial descritivo, a programação de longo prazo em cronograma de barras, cronograma financeiro e fluxo de desembolso, cronograma de suprimento, e a planilha de medição com os critérios definidos. Mas antes da montagem do caderno, o Gerente de Planejamento aplica um check list padrão da empresa para verificação dos documentos elaborados e atendimento aos requisitos definidos pelo processo comercial.

Como na empresa A, a elaboração da programação de médio e curto prazo não é padronizada. Por isso, o Gerente da Obra com base na programação de longo prazo desdobra as tarefas e atividades em programações de médio prazo. O Gerente da Obra elabora uma programação mensal com base na programação de longo prazo e nas metas do fluxo de desembolso, garantindo assim o atendimento à meta de medição física e financeira. Na obra visitada, o Gerente da Obra monta uma planilha com o horizonte de um mês para esta análise, com as atividades atrasadas, as previstas para o período e o prazo para realização, que é transmitida ao Mestre da Obra e subempreiteiros em reuniões mensais, na primeira semana do mês. Durante o mês, geralmente após a primeira quinzena, é realizada nova reunião para acompanhamento das metas. Esta planilha elaborada pelo Gerente da Obra separa as atividades por empreiteiro, nos pavimentos e ambientes.

Do mesmo modo que ocorre na empresa A, nestas reuniões são discutidos as metas e os desvios, mas não há um padrão na empresa para o registro das justificativas dos desvios no médio e curto prazo.

$\mathrm{Na}$ empresa $\mathrm{B}$, por utilizar mão-de-obra subempreitada, não há a preocupação com o dimensionamento das equipes. As metas são passadas para os subempreiteiros e fica sob a responsabilidade destes a alocação dos recursos. Também não há um banco de dados de produtividade na empresa, sendo as durações estimadas nas programações fruto da experiência do planejador e de programações de obras semelhantes.

Para a solicitação de materiais, equipamentos e contratações, o Gerente da Obra deve encaminhar solicitação para o Departamento de Suprimento pelo sistema informatizado da empresa, que analisa a solicitação, negocia e efetua a compra ou contratação. Como também acontece na empresa A, o Departamento de Suprimento não possui a programação física da obra, prejudicando a análise e definição dos escopos de contratação. Ou seja, caso o Gerente 
da Obra não especifique claramente na solicitação de compra e contratação o escopo solicitado, podem ocorrer falhas nos fechamentos dos contratos.

Mensalmente, um estagiário do Departamento de Planejamento e Orçamento faz a medição do progresso físico da obra utilizando a planilha de medição entregue no Caderno da Obra. Esta planilha de medição possui as mesmas atividades do WBS da programação. Com o resultado da medição, é desenhada a curva "S" prevista e realizada para avaliação do progresso físico da obra.

Para o controle de custos e financeiro, o Gerente da Obra deve elaborar uma planilha com os custos incorridos até o período, obtidos no sistema informatizado, e a previsão dos custos futuros para cada grupo ou pacote de trabalho. Esta planilha de acompanhamento dos custos, a planilha resumo da medição com o progresso físico dos grandes grupos, ou pacotes de trabalho, e a curva "S" formam o relatório mensal.

Os relatórios são analisados em reuniões com o Gerente de Planejamento, Gerente da Obra e Diretoria de Construção, e podem ser levados à discussão no Comitê Técnico.

Para avaliar os desvios de planejamento, a empresa definiu faixas de variação aceitáveis. No primeiro mês de obra, é aceitável um desvio máximo de $2 \%$ no planejamento, no segundo mês de $5 \%$ e do terceiro mês em diante de $8 \%$. Segundo os entrevistados, alcançar estas metas é difícil mas estimula o comprometimento na definição da programação e no monitoramento do progresso.

Para auxiliar na análise de médio prazo da programação, mensalmente o Gerente de Planejamento encaminha ao Gerente da Obra uma listagem das atividades previstas para o próximo trimestre. O Gerente da Obra analisa as atividades previstas e datas de início e término, propondo alterações quando necessário. A listagem corrigida é devolvida ao Gerente de Planejamento, que simula no MS Project a intenção do Gerente da Obra, autorizando ou não as modificações propostas. Como apontado pelos entrevistados, esta análise auxilia bastante na visão do andamento da obra em termos de detalhamento das atividades e sequenciamento adotado, mas não está sendo praticada regularmente, pois demanda tempo do Gerente de Planejamento na elaboração das simulações.

Na obra visitada, para compensar a irregularidade na análise da listagem trimestral, o Gerente da Obra acompanha o progresso físico em gráficos esquemáticos desenhados de programação de longo prazo, simulando precedências de forma gráfica. Na obra visitada também são 
utilizados os controles esquemáticos do prédio que indicam com a pintura do pavimento a conclusão do serviço.

No final da construção, o Gerente da Obra e o Gerente de Planejamento elaboram o Relatório de Avaliação Final da Obra, com a avaliação dos índices de custo obtidos e a justificativa dos desvios na programação de longo prazo.

Como ocorre na empresa A, o processo de planejamento da produção também elabora os orçamentos das solicitações de modificação pelos clientes. Quando as modificações são aprovadas, cabe ao Gerente da Obra a programação e controle da execução das modificações nas programações de médio prazo, bem como as interferências de projetos não identificadas e revisões pela Coordenação de Projetos.

Cabe ressaltar que a empresa tem como procedimento a execução do apartamento modelo e a validação em reunião com Coordenação de Projetos, Gerente da Obra e Suprimento. No entanto, o Departamento de Planejamento e Orçamento não participa desta validação, sendo que este poderia ser um momento para a avaliação da programação definida.

\section{4) Controle do processo}

Além da aprovação pela Diretoria de Construção e Gerente da Obra, o Gerente de Planejamento aplica check list de verificação dos documentos elaborados.

\section{5) Saídas do processo}

As saídas do processo são os relatórios mensais e o relatório final de obra, já discutidos na operação.

Também são saídas as solicitações de compra e contratação que são resultado das necessidades de recursos da programação, mas que são negociadas pelo Processo de Suprimento.

\subsubsection{O processo de planejamento da produção na empresa $C$}

Na figura 3.9 é ilustrado o processo de planejamento da produção na empresa C e em seguida são descritos as entradas, os recursos, a operação, o controle e as saídas do processo. 


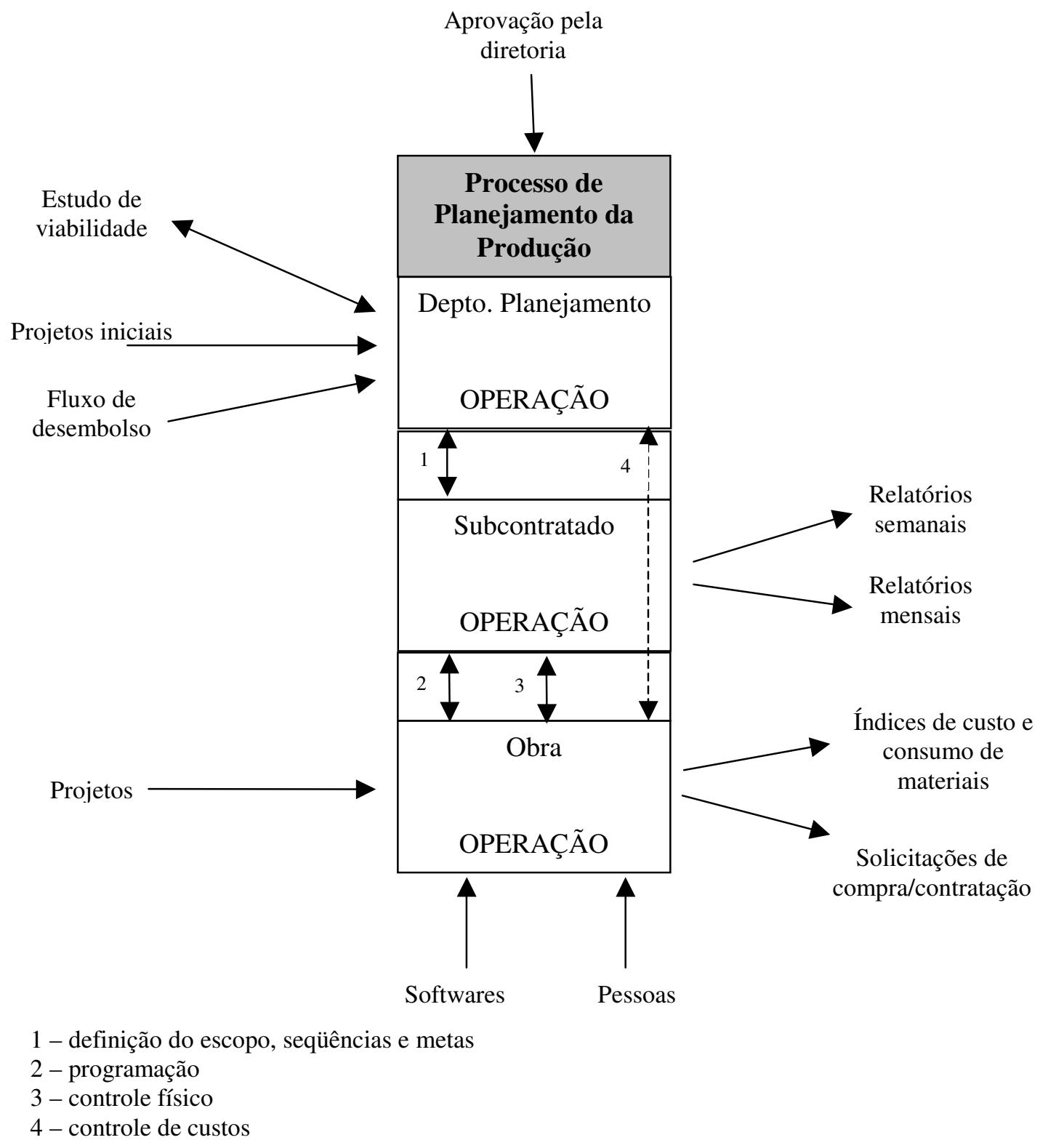

Figura 3.9 - Processo de planejamento da produção na empresa C

\section{1) Entradas do processo}

$\mathrm{Na}$ empresa $\mathrm{C}$ o início do processo é semelhante ao observado nas empresas A e B, com as informações recebidas do processo comercial variando quanto ao grau de detalhamento. $\mathrm{O}$ processo de planejamento da produção da empresa $\mathrm{C}$ também recebe do processo comercial a equação de fundos do empreendimento, ou fluxo de desembolso aprovado, no nível macro dos pacotes de trabalho, que define principalmente prazos da obra e fluxo de caixa. 
Quanto à interface com o processo de projeto, também ocorre na empresa $\mathrm{C}$ o recebimento dos projetos executivos e projetos para produção diretamente pela obra, encaminhados pela Coordenação de Projetos. Na obra estudada, é elaborado projeto para produção de alvenaria estrutural.

\section{2) Recursos do processo}

A empresa possui um Departamento de Orçamento, que executa o orçamento internamente. Este departamento responde diretamente à Diretoria da empresa.

A operação da programação e controle é subcontratada a uma empresa especializada, que atua com a equipe técnica nas obras sob a supervisão do Gerente de Obras. A empresa subcontratada utiliza na elaboração dos modelos da programação os softwares MS Project e o pacote Office.

Na obra, o Engenheiro da Obra, Mestres e Encarregados também são recursos do processo de planejamento da produção. As respectivas funções e responsabilidades foram descritas na seção 3.2.

Como na empresa A, a empresa C utiliza o sistema Sienge, com os módulos de orçamento, suprimento e custos.

\section{3) Operação do processo}

A empresa C também inicia a operação na etapa de estudo de viabilidade e concorrências, com a elaboração do orçamento preliminar no sistema Sienge.

Com as informações recebidas do processo comercial e do processo de projetos, o Gerente de Obras define o escopo, a seqüência e as metas dos períodos da construção, considerando principalmente o fluxo de desembolso. Este estudo é desenvolvido informalmente, sem registros das premissas ou critérios adotados. Contudo, como informado pelo entrevistado, a maioria das obras da empresa adota o sistema de alvenaria estrutural, sendo parte do conhecimento da empresa a programação de obras deste tipo, não havendo grandes variações.

O Gerente de Obras repassa este estudo, também informalmente, à empresa subcontratada, que irá operacionalizar a programação de longo prazo. 
Cabe ressaltar que a empresa $C$ adota a prática da subcontratação da operação da programação e controle a menos de um ano. Anteriormente, a empresa realizava este operação internamente, por um Engenheiro de Planejamento. No entanto, este cargo foi extinto da empresa e as funções repassadas aos engenheiros das obras. Mas a dificuldade na operacionalização, segundo informações dos entrevistados, levou à opção pela subcontratação da operação deste processo.

A empresa subcontratada elabora a programação de longo prazo em MS Project e valida com o Engenheiro da Obra. A apresentação do cronograma de barras do MS Project é complementada com gráficos elaborados com a técnica de LOB. Esta programação é elaborada para os serviços da torre, sendo que a programação dos serviços de periferia é elaborada pelo Engenheiro da Obra. Isto porque, segundo os entrevistados, os serviços de periferia possuem muitas interferências sendo mais fácil a programação e controle pela obra.

Após a aprovação da programação de longo prazo, a empresa subcontratada elabora as programações de médio e curto prazo, com os períodos de um mês e uma semana respectivamente.

Semanalmente são realizadas reuniões na obra com a empresa subcontratada, Mestre de Obra e Encarregados para comunicação das metas e acompanhamento do progresso físico. A empresa gera relatórios semanais com as metas atingidas e uma avaliação de cumprimento de metas de cada empreiteiro. Nesta avaliação dos subempreiteiros são consideradas as atividades programadas e que tinham frente de serviço liberada, e as atividades programadas mas que por algum motivo, como atraso na conclusão da etapa antecessora, não tinham frente de serviço liberada. Mensalmente, são emitidos relatórios com a avaliação do progresso físico mensal.

O Engenheiro da Obra é responsável pelo acompanhamento dos custos e responde diretamente ao Gerente de Obras, mas não há relatório formal com os resultados.

Como ocorre nas empresas A e B, não há um padrão para o registro das justificativas dos desvios no planejamento.

Também como na empresa B, não há a preocupação com o dimensionamento das equipes pois a mão-de-obra é subempreitada.

Para a solicitação de materiais, equipamentos e contratações, o Engenheiro da Obra encaminha a solicitação para o Departamento de Suprimento pelo Sienge, que analisa a 
solicitação, negocia e efetua a compra ou contratação. Do mesmo modo que ocorre nas empresa A e B, o Departamento de Suprimento não possui a programação física da obra, prejudicando a análise e definição dos escopos de contratação. Ou seja, caso o Engenheiro da Obra não especifique claramente na solicitação de compra e contratação o escopo solicitado, podem ocorrer falhas nos fechamentos dos contratos.

\section{4) Controle do processo}

O controle do processo é a aprovação da programação pela Diretoria, com base no fluxo de desembolso.

\section{5) Saídas do processo}

As saídas do processo são os relatórios semanais e mensais, já discutidos na operação.

Também são saídas as solicitações de compra e contratação que são resultado das necessidades de recursos da programação, mas que são negociadas pelo Processo de Suprimento.

\subsection{GESTÃo E INTEGRAÇÃO DO PROCESSO DE PLANEJAMENTO DA PRODUÇÃO}

Com base na estrutura organizacional da empresa apresentada na seção 3.1, no fluxograma ${ }^{14}$ dos processos principais da empresa e no mapeamento do processo de planejamento da produção e interfaces apresentado na seção 3.3, foram identificados os aspectos gerenciais e de integração do processo de planejamento da produção com os processos comercial, projeto, suprimento, financeiro, entrega de obra e assistência técnica e produtivo. O fluxo de atividades e informações do processo de planejamento da produção e interfaces das três empresas são apresentado nas figuras 3.10, 3.11 e 3.12 .

\footnotetext{
${ }^{14}$ Os fluxogramas dos processos principais das empresas não são apresentados neste trabalho por solicitação dos entrevistados, mas foram base da análise das interfaces do processo de planejamento da produção, pois demonstram com a empresa vê este processo inserido no fluxo.
} 


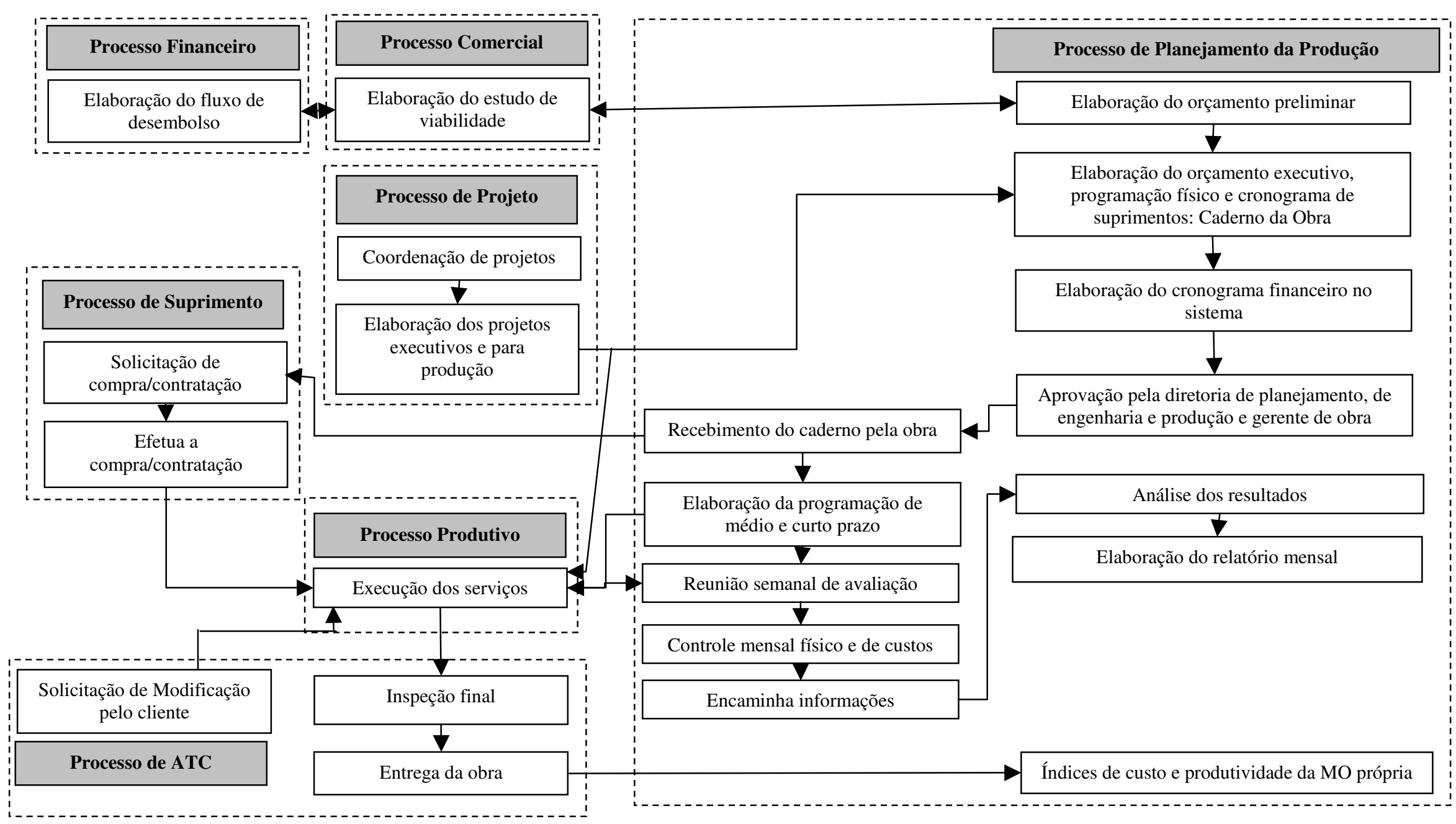

Figura 3.10 - Fluxo do processo de planejamento da produção e interfaces da empresa A 


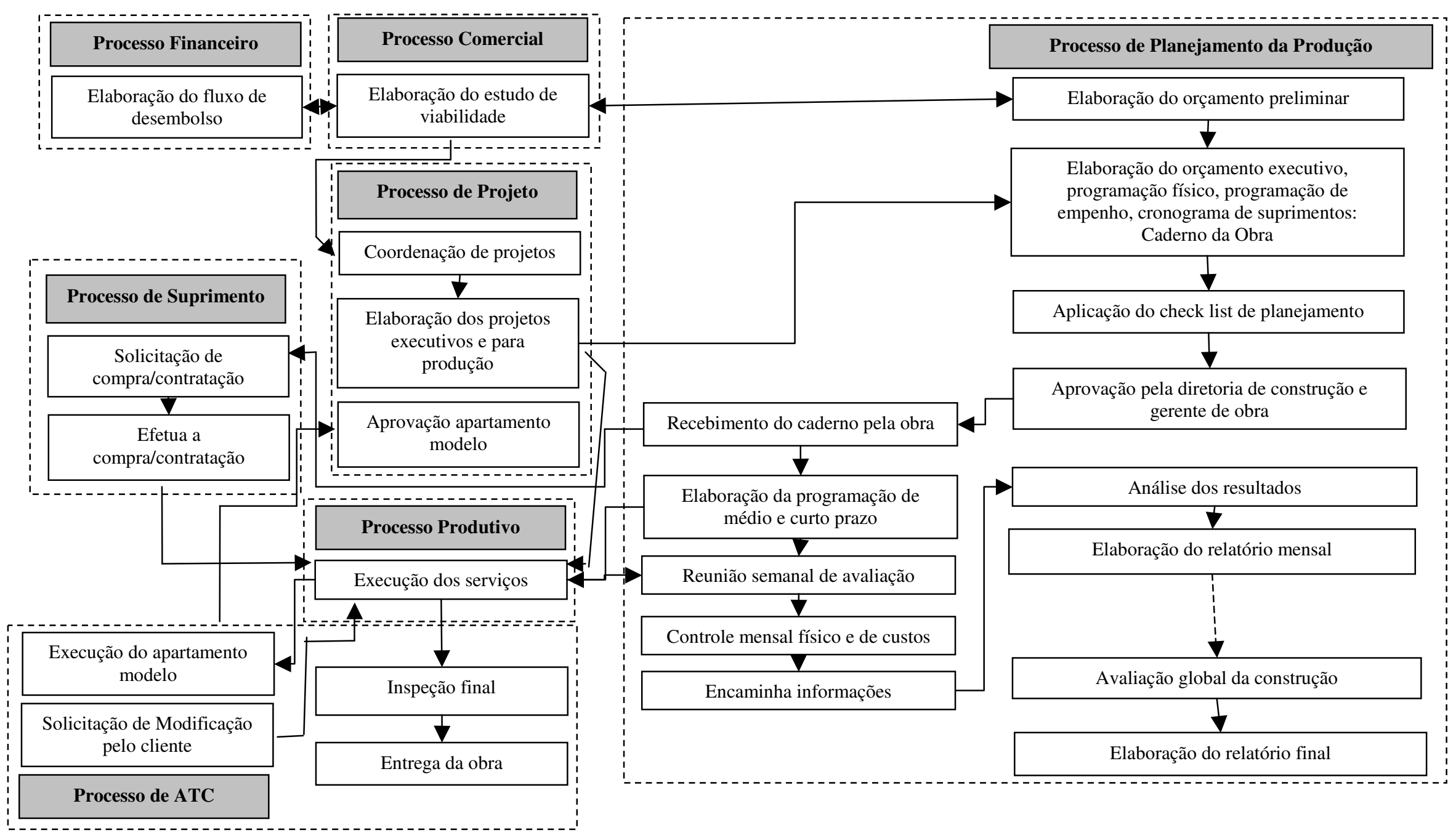

Figura 3.11 - Fluxo do processo de planejamento da produção e interfaces da empresa B 


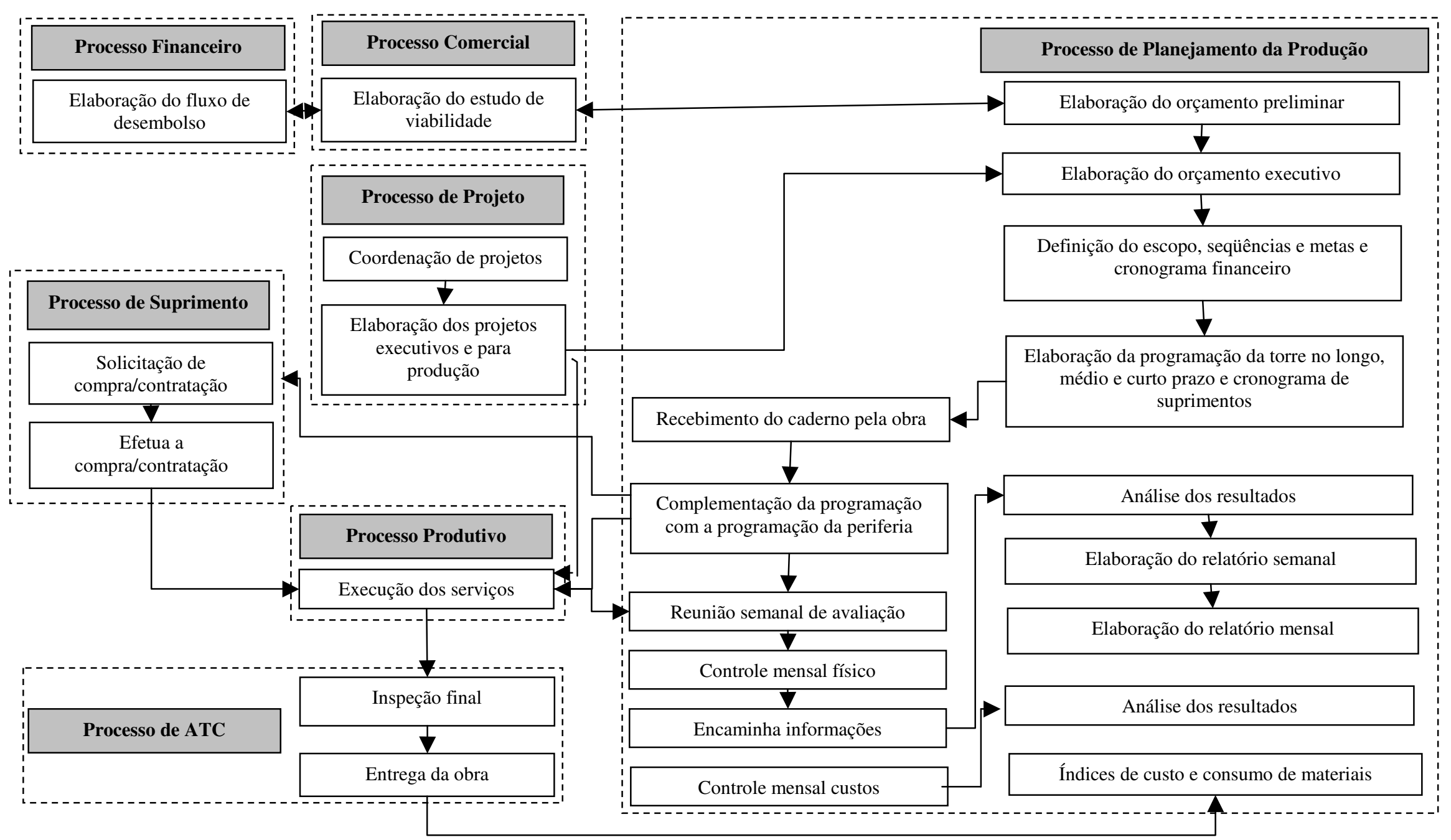

Figura 3.12 - Fluxo do processo de planejamento da produção e interfaces da empresa $\mathrm{C}$ 


\subsection{PROPOSTA DE AÇÕES DE MELHORIA NA GESTÃO E INTEGRAÇÃO DO PROCESSO DE PLANEJAMENTO DA PRODUÇÃO}

\subsubsection{Analise dos estudos de caso}

Nesta seção são discutidos os aspectos do processo de planejamento da produção a partir da confrontação do processo teórico apresentado no capítulo 2 com o processo prático estudado nas três empresas construtoras e apresentado nas seções anteriores deste capítulo.

1) Estrutura organizacional e modelos de gestão adotados

As três empresas construtoras são organizadas por departamentos segundo o critério de funcionalidade. Os departamentos interagem nas suas funções, como foi observado no mapeamento do processo de planejamento da produção. Com isso, diferentes departamentos possuem atuação direta no processo de planejamento da produção, ou seja, estes departamentos possuem responsabilidade definida neste processo.

Portanto, a visão de processo dentro da organização é justificada e promove a integração das equipes dos departamentos na execução de um trabalho comum a todos. Como já discutido na seção 3.1, as três empresas possuem a visão de processo, devido principalmente a adoção do sistema de gestão da qualidade como forma de gestão da organização.

2) O planejamento da produção como processo

\section{Entradas:}

As entradas do processo de planejamento da produção nas três empresas estudadas são semelhantes: o processo recebe informações da definição do empreendimento ainda no estudo de viabilidade (obras de incorporação) e participação em concorrências (obras por contrato), que são o memorial descritivo, projetos e edital de concorrência.

O nível de detalhamento da documentação recebida é bastante variável, principalmente em obras por contrato, que geralmente encaminham projetos básicos ou de prefeitura. Já nas obras de incorporação, as três empresas tem a preocupação com o detalhamento das informações encaminhadas ao processo de planejamento, e na maioria das vezes os projetos já 
são executivos e o memorial descritivo já define com detalhes os sistemas construtivos e acabamentos.

O processo de planejamento da produção nas três empresas também recebe como entrada a equação de fundos do empreendimento, ou fluxo de desembolso, no nível macro dos pacotes de trabalho, que define principalmente prazos da obra e fluxo de caixa.

Em nenhuma das empresas foi observada a padronização e formalização no recebimento desta documentação tanto em obras incorporadas pela empresa quanto por contrato.

No entanto, na empresa A é realizada uma reunião com as diretorias para definição das diretrizes de produção, como estratégias macro de produção, logística e tecnologia.

No estudo do processo teórico, as informações de entrada são obtidas do programa do empreendimento, um documento que formaliza: 1) as metas de negócio, referentes ao segmento de mercado ou demanda-alvo, seleção fundiária, custos do empreendimento, condições de financiamento, dependendo do tipo de empreendimento, velocidade de venda e rentabilidade desejada, etc.; b) requisitos funcionais, espaciais e operacionais que norteiem o desenvolvimento de produto; e c) requisitos de caráter construtivo como prazos, qualidade da obra, custos de construção, etc. Este programa serve para orientar não só o processo de planejamento da produção como também o processo de projeto.

Pode-se concluir que o processo de planejamento da produção das três empresas recebe as informações necessárias para a operação, sendo que em algumas situações, estas informações recebidas não têm a qualidade de detalhe requerida. No entanto, a falta de formalização das informações recebidas pelo processo de planejamento da produção dificulta a verificação do atendimento aos requisitos do estudo de viabilidade elaborado pelo processo comercial, que no processo teórico é denominado como programa do empreendimento.

\section{Recursos:}

Nas três empresas, os recursos do processo são pessoas e softwares de desenvolvimento de ferramentas de programação e controle, e de bancos de dados gerenciais e de cooperação entre os agentes, igualmente como discutido no processo teórico.

$\mathrm{Na}$ empresa $\mathrm{C}$ também tem a atuação da empresa subcontratada especializada, que substitui a equipe interna da empresa para a operação do processo. 


\section{Operação:}

No processo teórico são definidas as principais atividades do processo de planejamento da produção, que são:

a) coleta e análise das informações sobre a obra, que inclui análise dos projetos e especificações técnicas, conhecimento dos condicionantes físicos do local, conhecimento da disponibilidade e dos custos dos recursos disponíveis na região e conhecimento da trajetória ou desenvolvimento da obra;

b) identificação das etapas, atividades e serviços necessários para a execução da obra;

c) definição dos processos de trabalho (logística de suprimento e de canteiro);

d) levantamento de quantidades de serviços;

e) alocação de recursos (materiais, mão-de-obra e equipamentos) com estimativa das durações para cada serviço;

f) definição da seqüência tecnológica;

g) análise dos projetos para produção dos principais serviços, com a determinação por cada agente das necessidades de acesso ao canteiro de obras, estocagem dos materiais e componentes, posicionamento dos equipamentos;

h) elaboração da programação de atividades aprovada pelos envolvidos. Nesta programação também devem ser contemplados os prazos para contratação dos serviços que serão terceirizados, e materiais e equipamentos;

i) análise das equipes que podem influenciar a organização e o andamento dos trabalhos no canteiro de obras;

j) análise dos caminhos críticos, definindo-se soluções para as interfaces identificadas que podem vir a complicar o planejamento definido;

k) definição de responsabilidades como pela limpeza e pela remoção de entulho, que são atividades não identificadas na programação mas que podem afetar o andamento da obra; e

1) definição de uma agenda de reuniões para análise critica do processo de planejamento.

O processo de planejamento da produção, nas três empresas estudadas, não abrange todas as atividades apontadas como necessárias na operação do processo teórico e listadas de "a" a "l". 
A operação do processo da empresa A e B atende os itens “a, b, c, d, f, h, j, l”; atende parcialmente o item "e", pois as durações são estimadas pela experiência do planejador e não pela alocação dos recursos; e não atende os itens " $\mathrm{g}, \mathrm{i}, \mathrm{k}$ ".

Na empresa C, a operação do processo atende os itens " $b, d, f, h, j, l$ ”; atende parcialmente o item "a", pois a análise dos dados é realizada informalmente pelo Gerente de Obras, que repassa o resultado da análise, também informalmente, à empresa subcontratada; atende parcialmente o item “c”, pois a logística de canteiro é definida pela obra; atende parcialmente o item "e" pois as durações são estimadas pela experiência do planejador e não pela alocação dos recursos; e não atende os itens "i, k".

No estudo do processo teórico, os dados de entrada são trabalhados para a elaboração de modelos que simulam cenários projetados. Estes modelos "devem representar as variáveis e atividades deste processo, mostrando sequiências e trajetória para execução da obra, e os principais insumos e custos envolvidos na sua produção", ressalta Assumpção (1996). Além disso, os modelos devem ser aderentes às estratégias da empresa.

Mais do que isso, os modelos devem ser compreendidos pelos envolvidos; identificar as durações dos pacotes de trabalho; possibilitar atualização e modificação; alocar, monitorar e avaliar o uso dos recursos; apresentar estimativa de prazos exequíiveis; e ser compatível com outros modelos organizacionais de planejamento.

As três empresas elaboram modelos de longo prazo com o cenário esperado de produção, utilizando o software MS Project, que define redes de precedência com a aplicação da técnica de CPM. Portanto, são modelos determinísticos. Nas três empresas, os modelos definem a seqüência e trajetória para a execução da obra no longo prazo, mas não determinam o insumo mão-de-obra para a execução das atividades. A definição deste insumo é realizada posteriormente a aprovação do modelo de longo prazo, nas programações de médio e curto prazo, pela empresa A. As empresas B e C não dimensionam a mão-de-obra.

Quanto aos custos envolvidos na produção, na empresa A e B o modelo está relacionado ao controle de custos. Na empresa A, os custos de produção são obtidos pelo lançamento manual das informações geradas pelo modelo físico em MS Project no sistema Sienge, nos centros de custo do orçamento. Já na empresa B, os custos de produção são obtidos pela apropriação dos custos das atividades no modelo em MS Project, que distribui estes custos das atividades no tempo, e gera um cronograma por empenho. 
Já na empresa C, o modelo não possui relacionamento direto com os custos de produção. $\mathrm{O}$ modelo de longo prazo elaborado pela empresa subcontratada define a programação do progresso físico da obra. Fica sob responsabilidade do Engenheiro da Obra e do Gerente de Obras a adequação das metas definidas neste modelo para cumprimento das metas do fluxo financeiro. Como informado pelos entrevistados, geralmente tenta-se manter a programação física com metas de produção maiores do que as necessárias para cumprimento das metas do fluxo financeiro.

Nas três empresas os modelos são orientados pelo fluxo de desembolso, que possui relacionamento direto com as estratégias da empresa.

No estudo da empresa A foi verificado que quando o modelo tem que ser elaborado sobre projetos de prefeitura que ainda não possuem análise de interferência de sistemas como instalações, por exemplo, o planejador tem que conseguir visualizar o produto para identificar eventuais interferências para, por exemplo, prever a instalação de forros ou sancas de gesso. Estas premissas precisam ser validadas posteriormente a execução dos projetos executivos. No entanto, estas premissas são registradas apenas na estrutura do WBS da programação ou no sequenciamento das atividades, não havendo um documento que formalize a adoção das premissas ou a posterior validação.

Também não há uma ferramenta formal para verificação do atendimento pelo modelo dos requisitos previamente estabelecidos no processo comercial nas empresas A e C. Na empresa C é aplicado um check list após a aprovação do modelo de longo prazo para verificação do atendimento aos requisitos.

Nas entrevistas foi percebido que os modelos utilizados são compreendidos pelos envolvidos, e por ser elaborado em MS Project podem ser atualizados e modificados. No entanto, as três empresas não exploraram o modelo na alocação, monitoramento e avaliação do uso dos recursos, o que de certo modo prejudica na determinação dos prazos.

Não foi possível verificar nos estudos de caso a compatibilidade dos modelos utilizados com outros modelos organizacionais de planejamento.

O processo teórico também determina que os modelos devem ser mais detalhados no médio e curto prazo e contemplar o dimensionamento dos insumos para produção. No médio e curto prazo, devem ser analisados pequenos trechos do modelo de planejamento de longo prazo e os pacotes de trabalho devem ser divididos em tarefas e atividades. 
Nas empresas A e B, não há padronização e formalização na elaboração das programações de médio e curto prazo. Também não há um dimensionamento da mão-de-obra considerando a produtividade individual. A obra A que trabalha com mão-de-obra própria faz o dimensionamento das equipes mas considera uma produtividade média da equipe.

Na empresa $\mathrm{C}$, a empresa subcontratada elabora a programação de médio e curto prazo com as metas de progresso físico.

A empresa B faz simulações mensais no próprio MS Project com os dados de controle e com a previsão trimestral realizada pelo Gerente da Obra. De acordo com os entrevistados, esta análise auxilia bastante na visão do andamento da obra em termos de detalhamento das atividades e sequenciamento adotado.

No processo teórico, a base utilizada na estruturação do modelo de programação deve ser compatível com a que será utilizada para o sistema de controle. Além disso, o controle é dependente da coleta e acesso a informações confiáveis, de modo a permitir ações de curto prazo ou promover experiências de longo prazo.

As três empresas realizam o controle da produção. As empresas A e B utilizam a mesma estrutura de WBS para a programação e o controle. Além disso, a empresa B define, no início da obra, os critérios de medição na planilha de medição dos serviços do Caderno da Obra e define faixas de variação aceitáveis para avaliar os desvios de planejamento.

\section{Controle:}

No estudo do processo teórico, o controle do processo é realizado pela análise e validação do sistema de planejamento pelos envolvidos, que vão desde a diretoria da organização, até as equipes de produção. A análise e validação pela diretoria indicam que o processo de planejamento da produção é executado dentro dos conceitos e do programa do empreendimento, e é capaz de fornecer as informações necessárias para o processo decisório da alta gerência. Já a validação pelas equipes de produção e demais envolvidos, demonstra a aceitação e o comprometimento com as metas estabelecidas.

Nas três empresas, o controle do processo é realizado por reuniões de gerência e diretoria. A empresa B também possui check list para o acompanhamento do processo. 


\section{Saídas:}

No subsistema de controle, no processo teórico, as informações devem: a) ser separadas conforme a responsabilidade; b) apresentar os resultados de maneira apropriada; c) ser apresentadas no período necessário; d) estarem disponíveis em tempo para que as decisões possam ser tomadas; e) despender o mínimo de energia da alta administração; e f) mostrar claramente os desvios do plano ou as exceções que aceitam tolerância.

As empresas A e B elaboram relatórios mensais com os resultados físico e de custos da obra, que são analisados pelas gerências para a tomada de ações, quando necessário. Já a empresa C elabora relatórios semanais com a avaliação das metas e subempreiteiros e relatórios mensais de progresso físico. A empresa $\mathrm{C}$ não elabora relatórios formais de controle de custos. $\mathrm{A}$ empresa B também elabora um relatório de avaliação final de obra com o resultado final do controle dos custos e justificativa para os desvios da programação de longo prazo.

Nas três obras estudadas, não há registro formal das justificativas dos desvios no médio e curto prazo. Na obra $\mathrm{A}$, as justificativas são registradas em diário de obra mas não há avaliação posterior.

\section{3) Análise das interfaces}

\section{Processo de planejamento da produção e processo comercial:}

Uma das principais interferências identificadas no processo teórico é quanto à realização do estudo de viabilidade sem consulta à equipe de produção ou planejamento. Soluções inicialmente definidas e programadas no estudo de viabilidade mas que não são efetivamente possíveis de serem executadas na obra, podem acarretar alteração do sequenciamento das atividades, e conseqüente alteração do fluxo econômico.

Nas empresas estudadas, existe a consulta à equipe de produção e planejamento mas não é formal. O processo de planejamento da produção também participa do estudo de viabilidade na elaboração dos orçamentos preliminares.

Outro ponto apontado no estudo do processo teórico é a definição do prazo da obra pela equação de fundos. O planejamento da produção que precisa adequar a construção à equação de fundos do empreendimento, sem atentar para o melhor aproveitamento dos recursos. 
Nas três empresas estudadas este aspecto de interferência não é sentido pois os modelos não trabalham com alocação de recursos de mão-de-obra e materiais, sendo o dinheiro o recurso considerado na montagem do modelo, do fluxo de desembolso.

Como apontado no estudo do processo teórico, o processo comercial adota critérios na definição do empreendimento que podem interferir no processo de produção de um empreendimento, como no caso das personalizações. As modificações de unidades por solicitações do cliente alteram o sequenciamento dos serviços e é gerado grande volume de retrabalho. Por isso, a aceitação de modificações pelo cliente deve ser considerada como umas das informações de entrada na elaboração da programação para a simulação de cenários com os tipos de modificações ainda no estudo de viabilidade, considerando estes cenários na análise de risco do empreendimento. Assim, as interferências externas podem ser previstas e os impactos calculados na programação da construção, podendo também ser monitorados.

A empresa C não adota a estratégia de marketing das personalizações em seus empreendimentos. Já as empresas A e B aceitam modificações pelo cliente mas não foram realizadas análises ou simulações dos impactos destas modificações no planejamento da obra.

\section{Processo de planejamento da produção e processo de projeto:}

No estudo do processo teórico foi identificado que a falta de detalhamento dos projetos com relação a especificações, métodos construtivos e seqüências, faz com que estas características tenham que ser definidas pelo processo de planejamento da produção como, por exemplo, quando programações são elaboradas com base em projetos básicos ou ante-projetos. Em situação mais desfavorável, estas características também passam pelo processo de planejamento sem definição, e acabam sendo decididas pelo engenheiro de obra, mestres e oficiais, sem tempo e sem condições adequadas durante a construção, como comentado por Picchi (1993).

No detalhamento dos projetos do produto são adotados os projetos para produção que definem a seqüência de atividades de obra e frentes de serviço, os equipamentos necessários e a organização de canteiro. No entanto, o desenvolvimento tardio destes projetos não proporciona a integração com o processo de planejamento da produção, que acaba, muitas vezes, adotando soluções diferentes das solicitadas pelos projetos para produção. 
Como já discutido na análise dos estudos de caso, a falta de detalhamento dos projetos faz com que o planejador adote premissas na elaboração dos modelos. No entanto, como verificado na empresa $\mathrm{A}$, estas premissas não são registradas formal e claramente de modo que possam ser verificadas posteriormente quando os projetos são detalhados. Além disso, nas três obras visitadas há a utilização de projetos para produção mas estes não foram considerados na elaboração da programação de longo prazo.

Também foi verificado que, nas três empresas, após a elaboração da programação de longo prazo e o início da construção, os projetos são encaminhados pela coordenação de projetos diretamente para a obra, sem a análise e muitas vezes conhecimento do planejador. Na obra, a equipe técnica avalia os projetos quanto às possíveis interferências na programação física da obra e, quando alguma alteração na programação é necessária, esta é realizada na programação de médio e curto prazo. Somente quando acontecem grandes desvios é realizada a reprogramação de longo prazo.

\section{Processo de planejamento da produção e processo de suprimento:}

No estudo do processo teórico verificou-se que a falta da informação correta de quando, quanto e como os recursos serão alocados na obra pode prejudicar a negociação que deve ser realizada pelo processo de suprimento. Não só prejudica a negociação mas também o progresso físico da obra pois a compra ou contratação dos recursos sem concordância com as seqüências e pacotes de trabalho definidas no planejamento da produção, podem provocar alterações de sequiência e interferências entre serviços.

Neste aspecto, as contratações mais críticas são os subempreiteiros. A contratação dos subempreiteiros considerando o orçamento e a programação, e a posterior análise destas ferramentas, evitam problemas de definição de escopo e de integração entre os serviços. Os serviços subempreitados são, na maioria das vezes, interdependentes na sua trajetória e seqüência. Problemas de contratação não afetam apenas o custo do serviço diretamente contratado, mas podem afetar o desempenho do empreendimento como um todo, pelo comprometimento de prazos e qualidade.

Nas três empresas estudadas, o gerente da obra é responsável pela solicitação de compra e contratação, que é encaminhada ao processo de suprimento via sistema informatizado. As compras e contratações são controladas pelos insumos e serviços registrados no orçamento 
que é elaborado no sistema informatizado e é o balizador dos custos de compras e contratações. Caso o gerente da obra não especifique claramente o escopo da compra e contratação na solicitação, podem ocorrer interferências pois o processo de planejamento não analisa a programação da obra no fechamento da compra e contratação, sendo o parâmetro apenas o insumo e o custo do orçamento.

\section{Processo de planejamento da produção e processo financeiro:}

No estudo do processo teórico foi identificado que os processos e estratégias de produção devem atender a equação de fundos montada para viabilizar o empreendimento.

Foi verificada, nas três empresas, grande preocupação com as metas da equação de fundos e controle de custos.

\section{Processo de planejamento da produção e processo de entrega de obra e assistência técnica:}

Foi observado no estudo do processo teórico que o processo de entrega de obra é raramente inserido na programação da obra, sendo que este é um processo extremamente importante para garantia da qualidade final do produto que é entregue ao cliente.

$\mathrm{Na}$ empresa A, a etapa de inspeção final e entrega de obra é prevista na programação de longo prazo do empreendimento, considerando várias etapas de inspeção e execução de reparos até a entrega final.

Nas empresas B e C não foi observada a previsão destas etapas na programação.

A empresa B adota como prática a execução de um apartamento modelo para análise e validação dos projetos e acabamentos. Para esta validação, é realizada uma reunião com a coordenação de projetos, suprimento e gerente de obra. Não há a participação do departamento de planejamento. No entanto, este poderia ser um momento para validação da programação da obra, com análise de interferências nas seqüências planejadas.

\section{Processo de planejamento da produção e processo produtivo:}

No estudo teórico do processo foi identificado que são poucas as empresas que estruturam o planejamento operacional no curto prazo. No entanto, é o planejamento operacional de curto 
prazo que é utilizado para transmitir à equipe de produção as metas diárias ou semanais. Também é neste nível que são definidos a alocação dos recursos, como mãos-de-obra e materiais, às tarefas e atividades. Ou seja, o planejamento operacional de curto prazo é o nível do planejamento mais próximo à execução.

Na empresa $\mathrm{C}$ é elaborada a programação de curto prazo pela empresa subcontratada, que é comunicada à equipe de produção nas reuniões semanais.

Nas empresas A e B, a programação de curto prazo é elaborada pelo gerente da obra, sem padronização ou formalização. Cada gerente de obra define um método para elaborar e controlar as programações de curto prazo.

Nas três empresas, não é feito o dimensionamento da mão-de-obra com alocação das equipes às tarefas programadas. $\mathrm{Na}$ empresa $\mathrm{A}$, ainda é feito o dimensionamento por equipe, mas sem a preocupação com a produção ou tarefa individual, para a mão-de-obra própria. Já na empresa B, o dimensionamento das equipes é delegado aos subempreiteiros, que devem cumprir as metas estabelecidas.

\section{4) Subcontratação do processo}

Como estudado no processo teórico, o agente subcontratado promove a inserção na empresa e no empreendimento a especialização do trabalho. No entanto, se este agente é inserido em um ambiente sem a análise da integração deste serviço em um contexto pré-existente, o aproveitamento é muito baixo.

As empresas A e B executam internamente o planejamento. Já a empresa C optou pela subcontratação devido às dificuldades na operacionalização do processo, que ficava sob a responsabilidade do engenheiro da obra. Este agente é inserido no ambiente da obra, mas nem todas as informações são transmitidas. Com uma melhor integração e não apenas a operacionalização do processo, este agente poderia trazer mais benefícios ao processo de planejamento da produção da empresa.

5) Gestão de informações e gestão de pessoas

No estudo da gestão do processo teórico, verificou-se a importância das informações no sistema de planejamento. Desde a elaboração dos modelos até a emissão dos relatórios, as 
informações são a base do processo. Por isso a importância da qualidade da informação e de como a informação é gerenciada. Também foi verificado que o conhecimento é fundamental no processo de planejamento da produção, pois os planejadores utilizam o conhecimento para suprir deficiências das informações recebidas quando, por exemplo, adotam premissas na elaboração do modelo pois a única informação que possuem são os projetos básicos da obra.

Cabe colocar também que a comunicação é o meio empregado pelos gerentes de obra para transmitir seus planos e instruções para a ação; e pelos mestres e encarregados para coordenar atividades e controlar as operações. A comunicação promove um melhor entendimento através da descrição do que está sendo feito e o motivo pelo qual está sendo feito. Uma das barreiras da comunicação é a falta de efetiva coordenação das atividades.

Um dos principais aspectos quanto a gestão da informação observado nas três empresas é a execução de muitas atividades informalmente, sem registros das premissas adotadas e das ações tomadas. As empresas acabam perdendo grande parte de sua "memória", ou como definido no capítulo 2 , seu conhecimento.

Quanto à definição das equipes de trabalho do processo, as competências necessárias, suas responsabilidades e autoridades dentro do fluxo de processos da empresa e do empreendimento, a implantação do sistema de gestão da qualidade, nas três empresas, auxiliou no desenvolvimento de procedimentos que formalizam estas questões.

\subsubsection{Práticas bem sucedidas e propostas de ações de melhoria}

São apresentadas as práticas que já estão sendo aplicadas pelas empresas e que auxiliam a gestão deste processo, bem como as falhas detectadas nos estudos de caso com propostas de ações de melhoria.

\section{1) Práticas bem sucedidas}

- Realização de reunião na passagem das informações do processo comercial para o processo de planejamento da produção com as diretorias e gerentes envolvidos para definição das diretrizes de produção, como estratégias macro de produção, logística e tecnologia. 
- Aplicação de check list após a elaboração e aprovação da programação de longo prazo para verificação do atendimento aos requisitos definidos na etapa de estudo de viabilidade do empreendimento.

- Simulações no modelo com os dados de controle e com a previsão atualizada, para auxiliar na visão do andamento da obra em termos de detalhamento das atividades e sequenciamento adotado.

- Definição dos critérios de medição física no momento da elaboração da programação.

- Estabelecimento de indicadores para o monitoramento dos desvios de planejamento.

- Realização de reuniões com diretoria, gerência e equipes de produção para validação da programação, para que todos se comprometam com as metas estabelecidas.

- Elaboração de relatório de avaliação final da obra, com as justificativas dos desvios de programação, índices de progresso físico, custos e produtividade.

- Previsão das atividades de inspeção final e entrega de obra na programação de longo prazo.

\section{2) Propostas de ações de melhoria}

- Padronização e formalização da passagem das informações do processo comercial para o processo de planejamento da produção tanto em obras incorporadas pela empresa quanto por contrato.

- Elaboração do Programa do empreendimento.

- Execução de todas atividades previstas na operação do processo de planejamento.

- Dimensionamento da mão-de-obra, com análise da produtividade individual para a formação de equipes: explorar o modelo na alocação, monitoramento e avaliação do uso dos recursos.

- Integração da ferramenta de programação e sistemas informatizados de gestão.

- Integração do sistema de planejamento físico com o sistema de planejamento de custos. 
- Formalização das premissas adotadas na elaboração do modelo para posterior validação com os projetos executivos, projetos para produção e gerente da obra.

- Padronização e formalização da elaboração das programações de médio e curto prazo.

- Adaptação das ferramentas de programação e controle às necessidades funcionais das obras: grande volume de serviços, muitas interferências dos clientes, caráter repetitivo etc.

- Registro das justificativas dos desvios da programação no médio e curto prazo.

- Consulta formal à equipe de produção e de planejamento na etapa de estudo de viabilidade.

- Simulação de cenários em obras que aceitam modificações pelo cliente, ainda no estudo de viabilidade, com os tipos de modificações aceitas. Estas simulações devem ser consideradas na análise de risco do empreendimento. Assim, as interferências externas podem ser previstas e os impactos calculados na programação da construção, podendo também ser monitorados.

- Consideração dos projetos para produção na elaboração da programação de longo prazo.

- Análise das modificações de projeto durante a obra e os impactos na programação de longo prazo.

- Definição clara dos escopos de compra e contratação e análise em matriz de responsabilidade dos serviços, atividades e tarefas na obra.

- Execução do apartamento modelo para validação dos projetos, materiais, e planejamento, com a análise e aprovação do gerente da obra, gerente de suprimento, coordenador de projetos, assistência técnica e gerente de planejamento.

- Integração da empresa subcontratada especializada em planejamento.

- Manutenção de banco de dados de índices de produtividade, custos e consumo de materiais. 


\section{CONSIDERAÇÕES FINAIS}

Nesta seção são apresentados os comentários finais acerca da pesquisa apresentada em cada capítulo, do um ao terceiro. Os objetivos propostos pela pesquisa, global e parciais, são discutidos quanto ao seu atendimento. Finalmente, são apresentadas sugestões de temas para futuros trabalhos.

O primeiro objetivo parcial, que é a caracterização do processo de planejamento da produção foi alcançado e é apresentado nas seções 2.2 .2 e 3.3. A caracterização do processo de planejamento da produção evidenciou que as empresas possuem um processo de planejamento da produção estruturado, com responsabilidades e autoridades definidas, mas muitas das atividades realizadas no processo e nas interfaces ainda são informais e sem padronização.

Como ponto crítico na caracterização dos processos, não foi observada a preocupação com a adaptação das ferramentas de programação e controle às necessidades especiais das obras, ou seja, a análise da funcionalidade do planejamento no ambiente em que está inserido. Como observado nas obras estudadas, a obra A tem como principal característica o volume de serviços; a obra B sofre muitas interferências externas dos clientes; e a obra C tem predominantemente serviços repetitivos. A preocupação com a funcionalidade e adaptação das ferramentas é fundamental na inserção do planejamento da produção na realidade da obra.

O segundo objetivo parcial, a análise da integração do processo de planejamento da produção com os demais processos da empresa construtora permitiu a identificação das atividades e do fluxo de informações entre processos. No fluxo de processos principais da empresa construtora, o processo de planejamento da produção tem interferências de todos os processos. Portanto, a gestão deste processo condiciona o desempenho da empresa construtora, visto que a gestão do processo de planejamento da produção proporciona o desenvolvimento adequado do produto para o cliente final da construtora, o empreendimento. Este objetivo foi atendido e é apresentado nas seções 2.2.3 e 3.4.

O terceiro objetivo parcial, que é a análise do impacto da subcontratação do planejamento da produção, foi atendido e é apresentado nas seções 2.2.5 e 3.3.3. A subcontratação do planejamento da produção tende a ser benéfica à gestão do processo de planejamento da produção pois é inserido um serviço especializado no ambiente da empresa. No entanto, 
quando este agente externo não é integrado ao fluxo de processos da empresa, seu poder de atuação fica reduzido e as melhorias que poderiam ser implementadas tanto no processo quanto nos empreendimentos não são alcançadas. Como todo serviço especializado, deve estar bem contextualizado para agregar valor às atividades na qual pode exercer influência.

O quarto objetivo parcial, a identificação do fluxo de informações no processo de planejamento da produção e interfaces, e os modelos aplicados na gestão da informação e do conhecimento, foi alcançado e é apresentado nas seções 2.3, 2.4 e 3.4. No estudo teórico, foi analisada a importância da informação e como a informação deve ser gerenciada. Também foram apresentados os aspectos da gestão de pessoas, que influenciam na formação das equipes de trabalham e na motivação da equipe. A informação é o principal recurso do processo de planejamento da produção, juntamente com o conhecimento dos profissionais que trabalham com planejamento e da própria empresa. Com isso, foi verificada a importância da manutenção de banco de dados nas empresas construtoras, e na formalização e registro das informações recebidas, processadas e enviadas pelo processo de planejamento da produção. Além da informação, as pessoas são os recursos que causam maior impacto na gestão do processo de planejamento da produção. A formação das equipes de produção, a liderança, e a motivação são fundamentais para que o sistema de planejamento funcione adequadamente na produção.

E o quinto objetivo parcial, a proposição de melhorias que poderiam ser implementadas na gestão do processo de planejamento, foi atendido e é apresentado na seção 3.5. Um dos aspectos positivos deste objetivo, que pôde ser observado no desenvolvimento desta pesquisa, é que parte das ações descritas na seção 3.5 são ações que as empresas estudadas já aplicam e que podem servir como referência para outras empresas. Também são propostas ações de melhoria para as falhas observadas na confrontação do processo de planejamento da produção teórico e dos processos mapeados nos estudos de caso.

O objetivo global desta dissertação, a caracterização e análise critica, com base em revisão bibliográfica e estudos de caso, da gestão do processo de planejamento da produção em empresas construtoras de médio e grande porte, em empreendimentos residenciais de médio e alto padrão na RMSP, foi atendido. Este trabalho permitiu, em um primeiro momento, a caracterização teórica e prática do processo de planejamento da produção, e em um segundo momento, a inserção deste processo no fluxo de processos principais da empresa. Através da análise do fluxo do processo e das interfaces com os demais processos do fluxo principal da 
empresa, foi possível caracterizar e analisar criticamente a gestão do processo de planejamento da produção.

Cabe ressaltar que os resultados obtidos com a pesquisa e a realidade encontrada nas três empresas estudadas não representam um padrão do total de empresas construtoras de médio e grande porte da RMSP. Apesar das empresas estudadas representarem uma amostra não houve a preocupação nesta pesquisa com a quantificação ou extrapolação dos resultados, como já observado no capítulo 1 deste trabalho.

Cabe aqui sugerir temas para trabalhos futuros que podem complementar a pesquisa aqui realizada:

(1) identificar as principais causas dos desvios do planejamento da produção e aplicar estudo estatístico para a ocorrência destes desvios

(2) análise quantitativa do impacto das modificações solicitadas pelo cliente durante a obra, e como isto pode ser simulado com cenários e análise de risco

(3) utilização do apartamento modelo para estudo das interfaces e melhoria dos processos construtivos, bem como da programação 


\section{ANEXOS}

Anexo A - Questionário 1: Caracterização da empresa

Anexo B - Questionário 2: Análise do processo de planejamento - aplicação no escritório da empresa

Anexo C - Questionário 3: Análise do processo de planejamento - aplicação no empreendimento tomado como amostra

Anexo D-Questionário 4: Análise do processo de planejamento - equipe de produção

Anexo E-Questionário 5: Análise do processo de planejamento - empresa subcontratada 


\section{ANEXO A - Questionário 1 - Caracterização da empresa}

Este é um questionário inicial para caracterização da sua empresa:

\begin{tabular}{|l|l|}
\hline Nome da empresa & \\
\hline Endereço & \\
\hline Telefone & \\
\hline $\begin{array}{l}\text { Responsável pelas } \\
\text { informações }\end{array}$ & Nome - Função - Formação - E-mail \\
\cline { 2 - 2 } & \\
\hline Data da entrevista & \\
\hline $\begin{array}{l}\text { O nome da empresa } \\
\text { pode ser divulgado? }\end{array}$ & \\
\hline
\end{tabular}

FORMAÇÃO DA EMPRESA

Data da fundação

Fundadores

Atuais proprietários

Razão social

FILOSOFIA DA EMPRESA

Possui Sistema de Gestão da Qualidade?

Ou outro sistema de gestão? 


\begin{tabular}{|c|c|c|c|}
\hline \multicolumn{4}{|c|}{ PORTE DA EMPRESA } \\
\hline \multicolumn{4}{|l|}{$\begin{array}{l}\text { Número de funcionários } \\
\text { próprios (escritório + adm de } \\
\text { obra) }\end{array}$} \\
\hline \multicolumn{4}{|l|}{$\begin{array}{l}\text { Número de funcionários } \\
\text { terceirizados nos processos } \\
\text { principais (escritório + adm de } \\
\text { obra) }\end{array}$} \\
\hline \multirow{7}{*}{$\begin{array}{l}\text { Número de obras executadas } \\
\text { (em número de } \\
\text { empreendimentos) }\end{array}$} & \multirow{3}{*}{ Residenciais } & Popular & \\
\hline & & Médio & \\
\hline & & Alto & \\
\hline & Comerciais & & \\
\hline & Industriais & & \\
\hline & Públicas & & \\
\hline & Outras & & \\
\hline \multicolumn{4}{|l|}{$\mathrm{m}^{2}$ de área construída } \\
\hline \multirow{7}{*}{$\begin{array}{l}\text { Número de obras em } \\
\text { andamento } \\
\text { (em número de } \\
\text { empreendimentos) }\end{array}$} & \multirow{3}{*}{ Residenciais } & Popular & \\
\hline & & Médio & \\
\hline & & Alto & \\
\hline & Comerciais & & \\
\hline & Industriais & & \\
\hline & Públicas & & \\
\hline & Outras & & \\
\hline $\mathrm{m}^{2}$ em andamento & & & \\
\hline
\end{tabular}




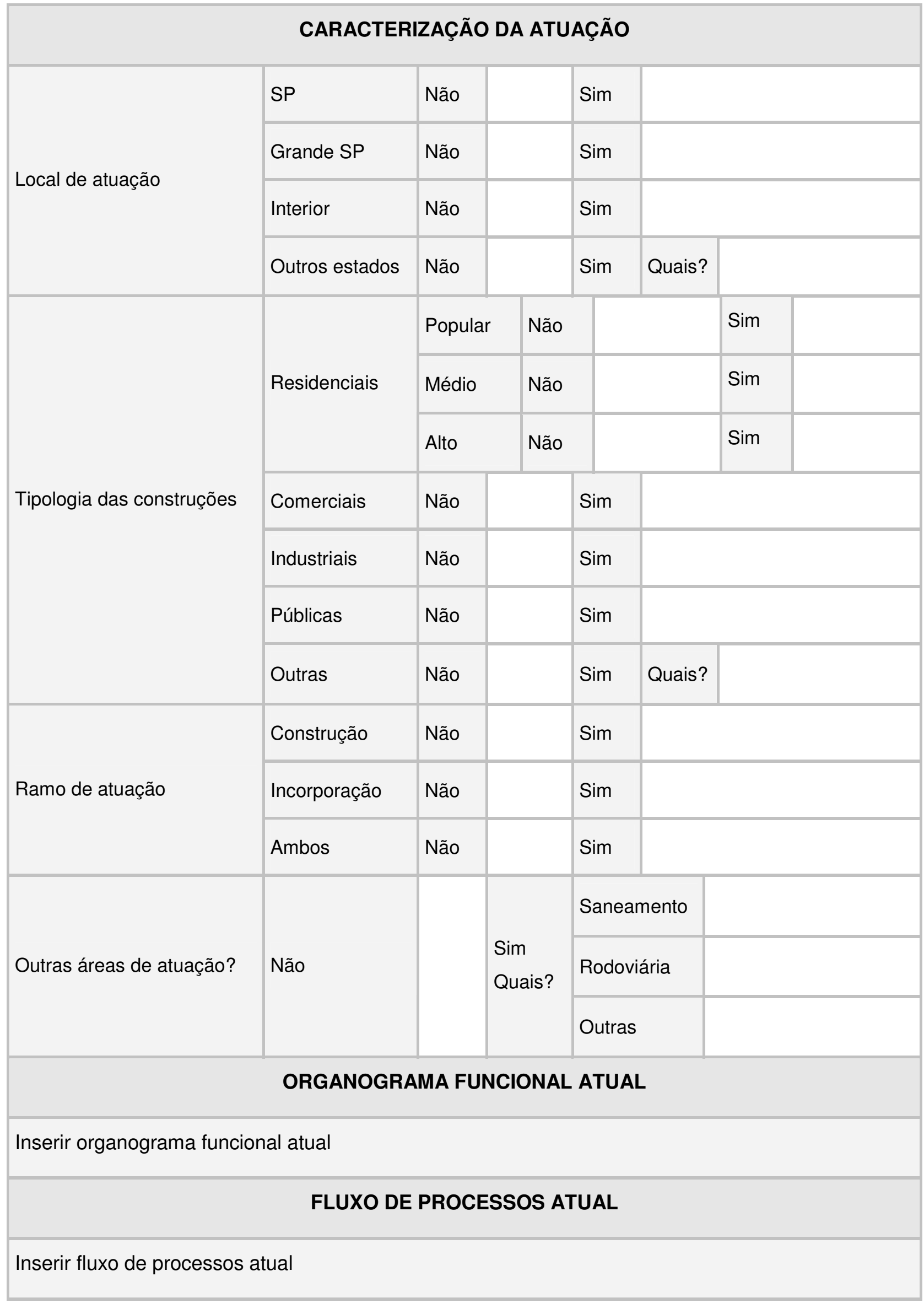




\section{ANEXO B - Questionário 2 - Análise do Processo de Planejamento}

Questionário aplicado no escritório da empresa

\begin{tabular}{|l|l|}
\hline Nome da empresa & \\
\hline $\begin{array}{l}\text { Responsável pelas } \\
\text { informações }\end{array}$ & Nome - Função - Formação - E-mail \\
\cline { 2 - 2 } & \\
\hline Data da entrevista & \\
\hline
\end{tabular}

\section{PROCESSO DE PLANEJAMENTO - ESTRUTURAÇÃO}

1) Existe uma equipe interna de planejamento?

1.a) Se sim, quantos funcionários e quais as funções? Desempenham outra função além das relacionadas ao processo de planejamento?

1.b) Se não, por que este processo é subcontratado?

1.b.1) Nos processos de concorrência ou seleção da empresa de planejamento subcontratada, quais os requisitos de competência técnica ou capacidade gerencial que os agentes têm que demonstrar para a pré-qualificação? Analisa-se a experiência passada em empreendimentos similares?

1.b.2) Quem é responsável pela qualificação e contratação?

1.b.3) Quem gerencia internamente este agente subcontratado?

1.b.4) Como este agente subcontratado é integrado? 
2) Em que momento de desenvolvimento do empreendimento é iniciado o planejamento da produção? Por quê?

3) Quais são as entradas do processo de planejamento? (o que, como, quando) São verificados os requisitos do cliente, identificados da definição do produto? Quem fornece as entradas? Quem analisa as entradas? Quem trabalha com as entradas?

4) Quais ferramentas são utilizadas? Por quê?

5) Como o processo é operacionalizado? Quem operacionaliza?

6) Como controla o processo?

7) Quais são as saídas? (o que, como, quando)

8) Como comunica os resultados? (o que, como, quando, para quem)

9) Como toma ações e retro-alimenta?

Identificar em todas as questões quem executa, controla, aprova e decide.

\section{ANÁLISE DE INTERFACES E INTEGRAÇÃO - GESTÃO E INTEGRAÇÃO}

1) Como é feita a coordenação do processo de planejamento com os demais processos (discriminar por processo identificado no fluxo de processos do questionário-1)? (pelo menos processo comercial, projeto, suprimento, financeiro, assistência ténica e obra) Quem coordena? Como coordena? Em que momento? 
2) Planejamento $X$ Comercial: como estão integrados com relação ao estudo de viabilidade, equação de fundos, estratégias de marketing (p.ex. modificações pelo cliente), confiabilidade?

3) Planejamento X Projeto: como estão integrados com relação ao programa do empreendimento, projetos para produção, controle de modificações?

4) Planejamento $X$ Suprimento: como estão integrados com relação a definição de prazos e recursos, contratações (escopo), medição de subcontratados?

5) Planejamento X Financeiro: como estão integrados com relação a fluxo de caixa, centro de custos, banco de dados?

6) Planejamento $X$ Assistência técnica: como estão integrados com relação a entrega de obra (prazos para inspeção final e reparos)?

7) Como está integrada a ferramenta utilizada pelo planejamento da produção com os demais processos, principalmente processo de controle de custos?

8) Existe banco de dados? Quais informações são coletadas? Quem tem acesso? Como é utilizada a informação?

\section{COMPETITIVIDADE DA EMPRESA}

1) Como o processo de planejamento da produção está integrado aos níveis superiores de planejamento da empresa (planejamento estratégico)?

2) Pode informar qual o custo do planejamento em relação ao custo do empreendimento? 
3) E o custo da manutenção em relação ao custo do empreendimento?

4) Vale a pena dispensar mais recursos com o aprimoramento do processo de planejamento para a melhoria da competitividade da empresa?

5) Já está sendo tomada alguma ação para desenvolvimento deste processo?

6) A diretoria tem conhecimento do planejamento da produção? Como isto é cobrado da equipe de produção? Como é cobrado dos demais processos (projeto, suprimentos, etc)?

\section{ANÁLISE GLOBAL}

1) Pontos fortes

2) Pontos fracos 


\section{ANEXO C - Questionário 3 - Análise do Processo de Planejamento}

Questionário aplicado no empreendimento tomado como amostra.

\begin{tabular}{|l|l|}
\hline Nome da empresa & \\
\hline $\begin{array}{l}\text { Nome do } \\
\text { empreendimento }\end{array}$ & \\
\hline $\begin{array}{l}\text { Responsável pelas } \\
\text { informações }\end{array}$ & Nome - Função - Formação - E-mail \\
\cline { 2 - 2 } & \\
\hline Data da entrevista & \\
\hline
\end{tabular}

\begin{tabular}{|c|c|c|c|}
\hline \multicolumn{4}{|c|}{ CARACTERIZACÃO DO EMPREENDIMENTO } \\
\hline \multicolumn{4}{|l|}{ Incorporação } \\
\hline \multicolumn{4}{|l|}{ Construção } \\
\hline \multicolumn{4}{|l|}{ Tipo } \\
\hline \multicolumn{4}{|l|}{ Padrão } \\
\hline \multicolumn{4}{|l|}{$\mathrm{m}^{2}$} \\
\hline \multicolumn{4}{|l|}{$\begin{array}{l}\text { no de pavimentos e } \\
\text { subsolos }\end{array}$} \\
\hline \multicolumn{4}{|l|}{$\mathrm{n}^{\circ}$ de unidades/pav } \\
\hline \multicolumn{4}{|l|}{$\begin{array}{l}\text { Características da } \\
\text { unidade tipo }\end{array}$} \\
\hline \multicolumn{4}{|l|}{ Início da construção } \\
\hline \multicolumn{4}{|l|}{ Prazo para entrega } \\
\hline \multicolumn{4}{|l|}{$\begin{array}{l}\text { Fase atual da } \\
\text { construção }\end{array}$} \\
\hline $\mathrm{n}^{\circ}$ de funcionários & próprios & subempreitados & \\
\hline
\end{tabular}




\begin{tabular}{|c|c|c|}
\hline \multirow{12}{*}{$\begin{array}{l}\text { Serviços } \\
\text { subempreitados }\end{array}$} & Locação & \\
\hline & Fundação & \\
\hline & Estrutura & \\
\hline & Vedação & \\
\hline & Instalações elétricas & \\
\hline & Instalações hidráulicas & \\
\hline & Revestimento interno & \\
\hline & Revestimento externo & \\
\hline & Pintura & \\
\hline & Esquadrias & \\
\hline & Impermeabilização & \\
\hline & Outros & \\
\hline \multicolumn{3}{|l|}{$\begin{array}{l}\text { Estrutura } \\
\text { organizacional da } \\
\text { obra }\end{array}$} \\
\hline Implantado SGQ? & & \\
\hline
\end{tabular}

CARACTERIZACÃO DO PLANEJAMENTO

\begin{tabular}{|l|l|l|}
\hline Realizado por & \multicolumn{2}{|l|}{} \\
\hline $\begin{array}{l}\text { Data da primeira } \\
\text { versão }\end{array}$ & $\begin{array}{l}\text { Data da versão } \\
\text { atual }\end{array}$ \\
\hline Ferramenta utilizada & & \\
\hline $\begin{array}{l}\text { Apresentado para } \\
\text { algum órgão? }\end{array}$ & \\
\hline
\end{tabular}




\section{PROCESSO DE PLANEJAMENTO NA OBRA}

1) PLANEJAMENTO E ORGANIZAÇĀO DAS ATIVIDADES NO TEMPO

1.a) Quando a obra iniciou, o planejamento físico já estava elaborado? Em que nível de detalhamento?

1.b) Como o processo de planejamento interfere/contribui na definição das tecnologias construtivas da obra? E na definição da seqüência das atividades?

1.c) Qual o menor período do planejamento (mês, semana, dia etc)? Quem detalha? Quando é feito o detalhamento?

2) IDENTIFICAÇĀO DOS RESPONSÁVEIS E REALIZAÇĀO DAS ATIVIDADES

2.a) Como são feitas a identificação e correlação dos responsáveis com as atividades planejadas (escopo de trabalho)?

2.b) As interferências entre as atividades são identificadas? São registradas e esclarecidas?

3) TRANSMISSÃO DAS INFORMAÇÕES E TOMADA DE DECISÕES

3.a) Como o planejamento é comunicado à gerência da obra? (quem comunica; quando; como)

3.b) Como o planejamento é comunicado à equipe de campo? (quem comunica; quem recebe a informação; quando; como)

3.c) Os responsáveis por receber a informação conhecem e entendem a ferramenta utilizada na comunicação (desde gerentes até equipes de campo)?

3.d) Como a obra decide por alterações de seqüências de atividades e como isso é definido no planejamento (a obra altera e depois comunica o planejamento ou é uma decisão comum)? E demais análises (custo, suprimentos, logística de canteiro...)? As equipes participam?

3.e) Os resultados alcançados são comunicados aos envolvidos (desde gerência até equipes)? (como, quando) 
4) CONTROLE

4.a) Como, quando e por quem o planejamento físico é avaliado com relação ao andamento da obra?

4.b) Como são tomadas ações para correção de eventuais desvios do progresso físico em relação ao planejamento? É analisado o impacto do desvio em qualidade, prazo e custo? Como?

4.c) A obra retroalimenta a base de dados da empresa? Como, quando e com quais informações? Quais os dados coletados (existe padronização na coleta)?

\begin{tabular}{|l|}
\hline ANÁLISE DE INTERFACES E INTEGRAÇÃO \\
\hline 1) Como a obra avalia a integração do planejamento com: \\
1.a) comercial: identificação dos requisitos dos clientes, solicitações de modificação \\
\hline 1.b) projetos: projetos executivos e detalhamento \\
\hline 1.c) suprimento: materiais, mão-de-obra, equipamentos \\
\hline 1.d) financeiro: plano de contas, fluxo de caixa \\
\hline 1.e) entrega de obra e assistência técnica: inspeção final e reparos \\
\hline 1.f) Sistema de Gestão da Qualidade: PQO (caso a empresa não possua SGQ, como o \\
planejamento contribui para a garantia da qualidade do produto) \\
2) A obra possui projetos para produção? Se sim, existe integração destes projetos com o \\
planejamento físico?
\end{tabular}


ANÁLISE GLOBAL

1) Pontos fortes

2) Pontos fracos 


\section{ANEXO D - Questionário 4 - Análise do Processo de Planejamento}

Questionário aplicado a equipe de produção, da obra estudada

\begin{tabular}{|l|l|}
\hline Empresa & \\
\hline $\begin{array}{l}\text { Responsável pelas } \\
\text { informações }\end{array}$ & Nome - Função - Formação \\
\cline { 2 - 2 } & \\
\hline Data da entrevista & \\
\hline
\end{tabular}

PROCESSO DE PLANEJAMENTO NA OBRA - EQUIPE DE PRODUÇÃO

1) PLANEJAMENTO E ORGANIZAÇĀO DAS ATIVIDADES NO TEMPO

1.a) Quando a obra iniciou, a programação já havia sido entregue a equipe de produção? Em que nível de detalhamento?

1.b) Como o processo de planejamento interfere/contribui no trabalho da equipe? E na definição da seqüência das atividades?

2) IDENTIFICAÇÃO DOS RESPONSÁVEIS E REALIZAÇÃO DAS ATIVIDADES

2.a) Como são feitas a identificação e correlação dos responsáveis com as atividades planejadas (escopo de trabalho) dentro da equipe de produção?

3) TRANSMISSÃO DAS INFORMAÇÕES E TOMADA DE DECISÕES

3.a) Como a programação é comunicada à equipe de produção? (quem comunica; quando; como)

3.b) Os responsáveis por receber a informação conhecem e entendem a ferramenta utilizada na comunicação (desde gerentes até equipes de campo)?

4) CONTROLE

4.a) Como a programação é avaliada pela equipe de produção?

4.b) Como são tomadas ações para correção de eventuais desvios do progresso físico? 
ANÁLISE GLOBAL

1) Pontos fortes

2) Pontos fracos 


\section{ANEXO E - Questionário 5 - Análise do Processo de Planejamento}

Questionário aplicado a subcontratados no processo de planejamento da produção.

\begin{tabular}{|l|l|}
\hline $\begin{array}{l}\text { Nome da empresa } \\
\text { construtora/obra }\end{array}$ & \\
\hline $\begin{array}{l}\text { Nome da empresa de } \\
\text { planejamento }\end{array}$ & \\
\hline Escopo de contrato & \\
\hline Telefone & \\
\hline $\begin{array}{l}\text { Responsável pelas } \\
\text { informações }\end{array}$ & Nome - Função - Formação - E-mail \\
\cline { 2 - 2 } & \\
\hline Data da entrevista & \\
\hline $\begin{array}{l}\text { O nome da empresa } \\
\text { pode ser divulgado? }\end{array}$ & \\
\hline
\end{tabular}

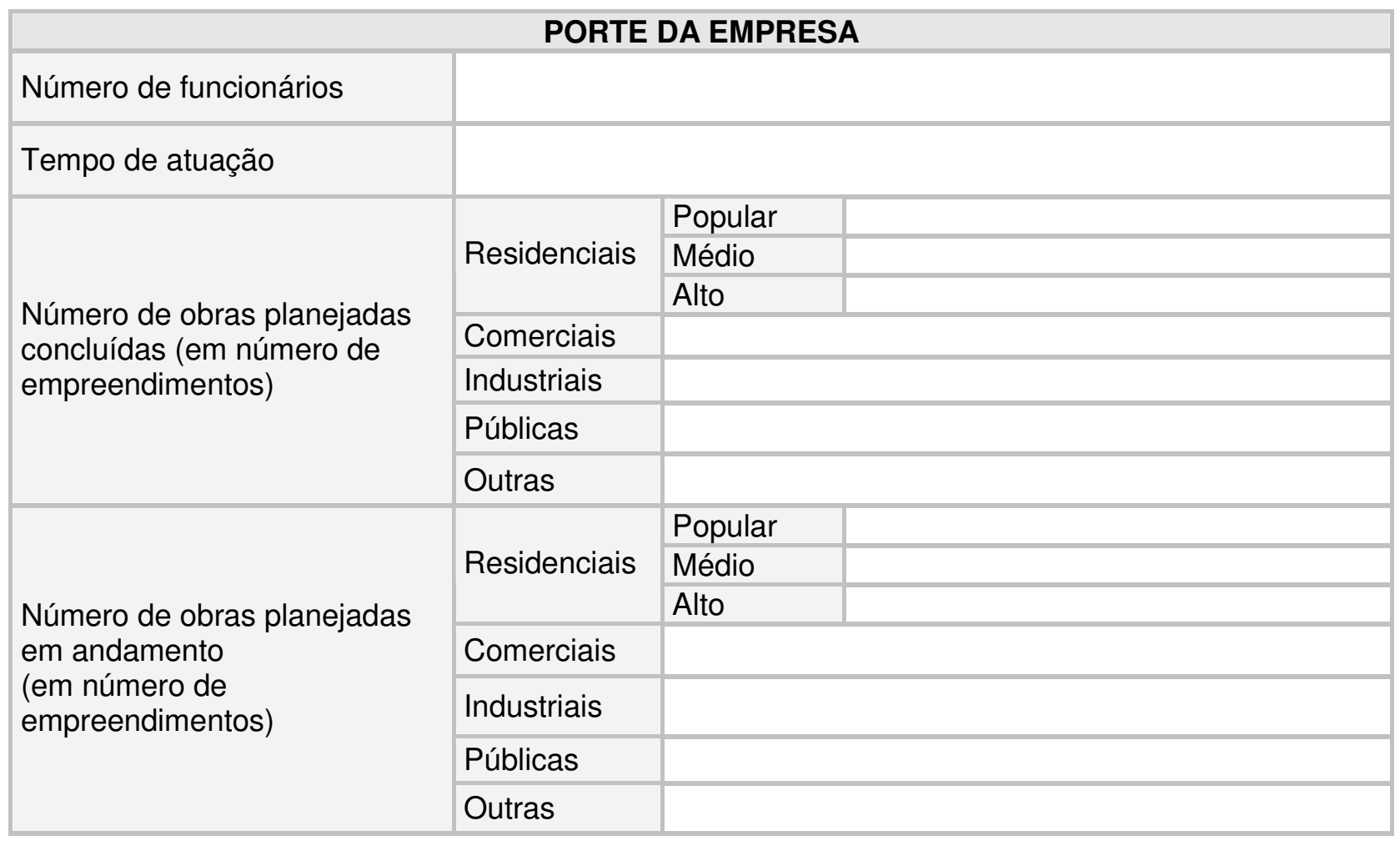




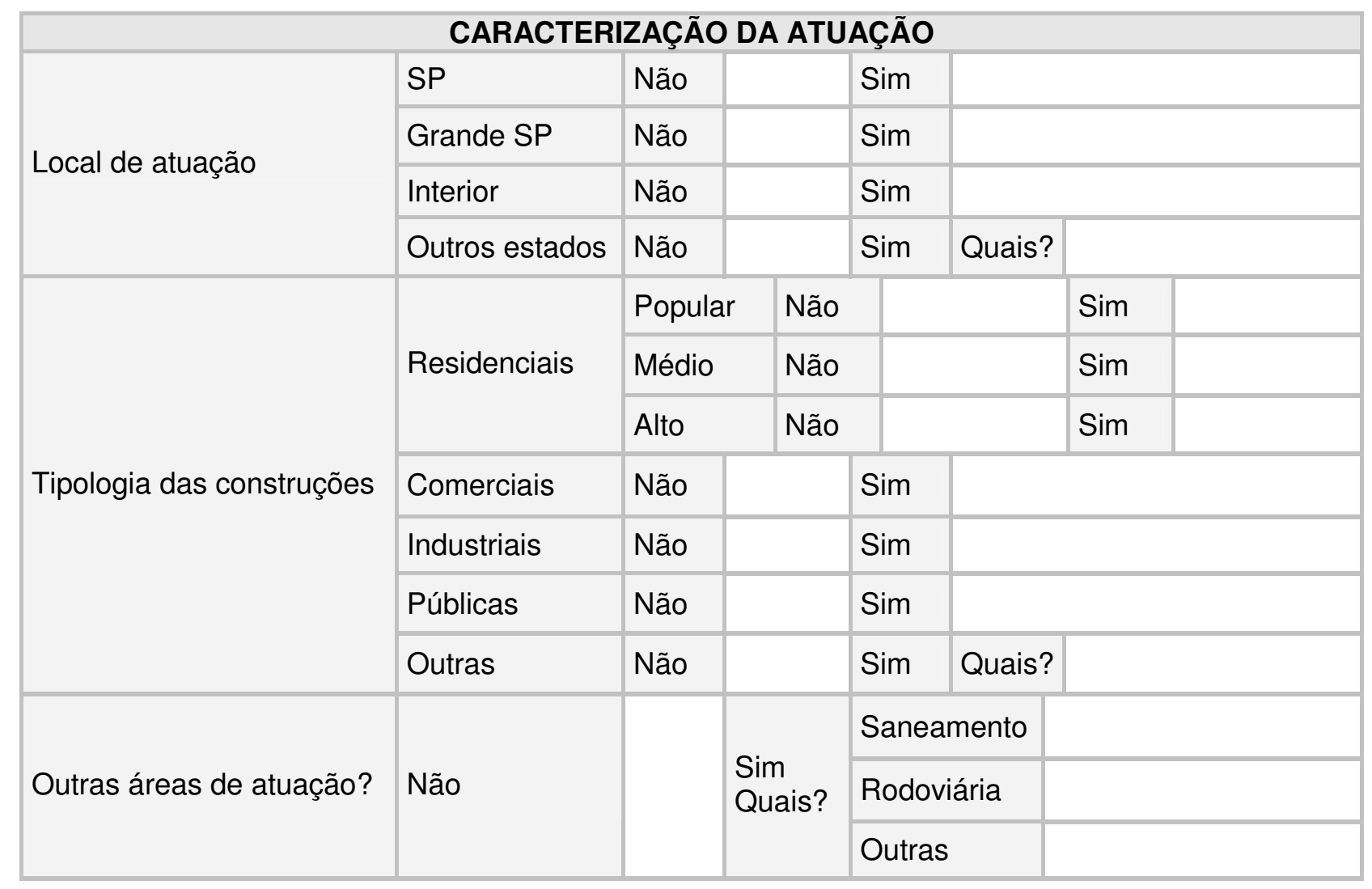

\section{PROCESSO DE PLANEJAMENTO}

1) Quais informações foram entregues para a elaboração da programação e como? Eram suficientes?

2) Como é feita a integração do trabalho de sua empresa na obra/empresa construtora?

3) Quais as responsabilidades da sua empresa? E autoridade (poder de atuação)?

4) As técnicas utilizadas na programação e controle são padrão da sua empresa ou podem ser adequadas de acordo com a necessidade da obra/construtora (cronogramas, relatórios, indicadores, etc)? 


\title{
REFERÊNCIAS BIBLIOGRÁFICAS
}

\author{
A GUIDE TO THE PROJECT MANAGEMENT BODY OF KNOWLEDGE - PMBOK \\ GUIDE - Project Management Institute - 2000.
}

AHUJA, H.N.; DOZZI, S.P.; ABOURIZK, S.M. Project management: techniques in planning and controlling construction projects. 2.ed. Nova York: Wiley, 1994.

ALMEIDA. L.G. Gerência de processo: mais um passo para a excelência. Rio de Janeiro: Qualitymark, 1993.

AMORIM, S.R.L. de. (a) Concepção partilhada: uma via para a integração técnica nas edificações. Rio de Janeiro, RJ. 1995. p.217-222. In: ENTAC 95, Rio de Janeiro, 1995. Artigo técnico.

AMORIM, S.R.L. de. (b) Tecnologia, organização e produtividade na construção. 1995. Tese (Doutorado) - Universidade Federal do Rio de Janeiro, Rio de Janeiro.

ASSOCIAÇÃO BRASILEIRA DE NORMAS TÉCNICAS (ABNT). NBR ISO 9000/ISO 9001: Sistemas da qualidade - requisitos. Rio de Janeiro, 2000.

ASSOCIAÇÃO BRASILEIRA DE NORMAS TÉCNICAS (ABNT). NBR ISO 10006: Gestão da qualidade - Diretrizes para a qualidade no gerenciamento de Projetos. Rio de Janeiro, 2000.

ASSUMPÇÃO, J.F.P.; FUGAZZA, A.E.C. Execução de orçamento por módulos para obras de construção de edifícios. Salvador, BA. 2000. v.1 p.469-476 il.. In: ENTAC, $8^{\circ}$, Salvador, 2000. Artigo técnico.

ASSUMPÇÃO, J.F.P. Gerenciamento de empreendimentos na construção civil: modelo para planejamento estratégico da produção de edifícios. 1996. Tese (Doutorado) - Escola Politécnica, Universidade de São Paulo, São Paulo.

BALLARD, G. Managing work flow on design projects. In: CIB W96 ARCHITECTURAL MANAGEMENT, Atlanta, 2000. Disponível em: <www.leanconstruction.org/readings> . Acesso em: 19 ago. 2003.

BERNARDES, M.M.S. Método de análise do processo de planejamento da produção de empresas construtoras através de seu fluxo de informação: proposta baseada em estudo de caso. 1996. Dissertação (Mestrado) - Escola de Engenharia, Universidade Federal do Rio Grande do Sul, Porto Alegre.

BERNARDES, M.M.S. Desenvolvimento de um modelo de planejamento e controle da produção para micro e pequenas empresas de construção. 2001. Tese (Doutorado) Escola de Engenharia, Universidade Federal do Rio Grande do Sul, Porto Alegre.

CALVERT, R.E.; COLES, D.C.H.; BAILEY, G.J. Introduction to building management. 6.ed. London: Butterworth - Heinemann Ltda, 1995. 
CARDOSO, F.F. Estratégias empresariais e novas formas de racionalização da produção no setor de edificações no Brasil e na França - parte 1. Estudos econômicos da construção Sinduscon, São Paulo, n.2, p.97-156, 1996.

CARDOSO, F.F. (a) Estratégias empresariais e novas formas de racionalização da produção no setor de edificações no Brasil e na França - parte 2. Estudos econômicos da construção Sinduscon, São Paulo, n.3, 1997.

CARDOSO, F.F. (b) Desenvolvimento de novas formas de gestão da produção. São Paulo, SP.1997. p.107-129. In: Seminário Internacional de Gestão e Tecnologia na Produção de Edifícios, 1997. Artigo técnico.

CINTRA, M.A.H.; AMORIM, S.R.L. de. Análise do sistema de informação em empresas construtoras de edificações por meio do D.F.D.: um estudo de caso. São Paulo, SP. 1998. p.363-370. In: Congresso Latino-Americano Tecnologia e Gestão na Produção de Edifícios: soluções para o terceiro milênio, São Paulo, 1998. Artigo técnico.

CLELAND, D.I.; KING, W.R. Project management handbook. 2.ed. Nova York: Van Nostrand Reinhold, 1988.

COHENCA, D.; LAUFER, A.; LEDBETTER, F. Factors affecting construction planning efforts. Journal of Construction Engineering and Management, v.115, n.1, p.70-89, 1989.

CONTADOR, J.C., coord. Gestão de operações: a engenharia de produção a serviço da modernização da empresa. São Paulo: Edgard Blucher, p.57-64, 1997.

DAVENPORT, T.H. Reengenharia de processos: como inovar na empresa através da tecnologia da informação. Rio de Janeiro: Campus, 1994.

DAVENPORT, T.H.; PRUSAK, L. Working knowledge: how organization manage what they know. Boston: HBS Press, 2000.

FABRÍCIO, M.M. Projeto simultâneo na construção de edifícios. 2002. Tese (Doutorado) - Escola Politécnica, Universidade de São Paulo, São Paulo.

FACHINI, A.C. Subsídios para a programação da execução de estruturas de concreto armado no nível operacional. 2005. Dissertação (Mestrado) - Escola Politécnica, Universidade de São Paulo.

FARAH, M.F.S. Tecnologia processo de trabalho e construção habitacional. 1992. Tese (Doutorado) - Faculdade de Filosofia, Letras e Ciências Humanas, Universidade de São Paulo, São Paulo.

FERREIRA, F.M.P.F.R. Benefícios da aplicação da ferramenta CPM no planejamento operacional e no controle físico da produção na indústria da construção civil: sub-setor de edificações. 2001. Dissertação (Mestrado) - Escola Politécnica, Universidade de São Paulo, São Paulo.

FISCHER, A. (a) Tendências em gestão de pessoas $-1^{\text {a }}$ parte. T\&D Inteligência 
Corporativa. São Paulo, v.13, n.138, p.58-63, 2005.

FISCHER, A. (b) A gestão do conhecimento - $2^{\mathrm{a}}$ parte. T\&D Inteligência Corporativa. São Paulo, v.13, n.139, p.62-66, 2005.

GOLDMAN, P. Sistema de planejamento e controle de custos na construção civil: subsetor edificações. 1999. Dissertação (Mestrado) - Escola de Engenharia, Universidade Federal Fluminense, Rio de Janeiro.

GOLDMAN, P. Introdução ao planejamento e controle de custos na construção civil brasileira. 4.ed. São Paulo: Pini, 2004.

HALPIN, D.W.; RIGGS, L.S. Planning and analysis of construction operations. Nova York: Wiley, 1992.

HALPIN, D.W.; WOODHEAD, R.W. Construction Management. Nova York: Wiley, 1980.

HALPIN, D.W.; WOODHEAD, R.W. Administração da construção civil. 2.ed. Rio de Janeiro: LTC, 2004.

HARRINGTON, H.J. Aperfeiçoando processos empresariais. São Paulo: Makron Books, 1993.

HARRIS, R. Creating continuous flow. In: LEAN SUMMIT, 2004. São Paulo, SP. Apresentações... São Paulo: Lean Institute Brasil, 2004.

ISATTO, E.L.; FORMOSO, C.T. Design and production interface in Lean Production: a performance improvement criteria proposition. In: CONFERENCE OF THE INTERNATIONAL GROUP FOR LEAN CONSTRUCTION, 6., 1998, Brasil: IGLC, 1998.

KERN, A.P.; FORMOSO, C.T. Integração dos setores de produção e orçamento na gestão de custos de empreendimentos de construção civil. São Carlos, SP. 2003. 9 p. SIMPÓSIO BRASILEIRO DE GESTÃO E ECONOMIA DA CONSTRUÇÃO, 3., 2003, São Carlos, SP.

KERZNER, H. Project management: a system approach to planning, scheduling and controlling. 4.ed. Nova York: Van Nostrand Reinhold, 1992.

KERZNER, H. Gestão de projetos: as melhores práticas. Porto Alegre: Bookman, 2002.

KOSKELA, L. Application of the New Production Philosophy to Construction. Stanford, CA: Center for Integrated Facility Engineering, Stanford University, 1992. (Technical Report, n. 72).

KRUGLIANSKAS, I.; TERRA, J.C.C. coord. Gestão do conhecimento em pequenas e medias empresas. 2. ed. Rio de Janeiro: Negócio Editora, 2003.

LAUFER, A.; TUCKER, R.L. Is construction project planning really doing its job? A critical examination of focus, role and process. Construction Management and Economics, London, vol.5, n.3, p.243-266, 1987.

LAWLOR, A. Productivity Improvement Manual. Westport: Quorum Books, 1985. 
LIBERATORE, M.J.; JONHSON, B.P.; SMITH, C.A. Project management in construction: software use and research directions. Journal of construction engineering and management, ASCE, v.127, n.2, p.101-107, mar. 2001.

LIBRELOTTO, L.I.; FERROLI, P.C.M.; RADOS, G.V. Custos na construção civil: uma análise teórica e comparativa. Florianópolis, SC. 1998. v.2 p. 399-406. In: Encontro Nacional de Tecnologia do Ambiente Construído, 7º, Florianópolis, 1998. Artigo técnico.

LIMA JR., J.R. Controle operacional na construção civil. 1978. Dissertação (Mestrado) Escola Politécnica, Universidade de São Paulo, São Paulo.

LIMA JR., J.R. (a) Sistemas de informação para o planejamento na construção civil: gênese e informatização. São Paulo: Escola Politécnica/USP, 1990. (BT/PCC/26)

LIMA JR., J.R. (b) Gerenciamento na construção civil: uma abordagem sistêmica. São Paulo: Escola Politécnica/USP, 1990. (BT/PCC/27)

LIMA JR., J.R. Qualidade na construção civil: conceitos e referência. São Paulo: Escola Politécnica/USP, 1993. (BT/PCC/120)

LIMA JR., J.R. Qualidade do empreendimento na construção civil: inovação e competitividade. São Paulo: Escola Politécnica/USP, 1995. (BT/PCC/144)

LIMA JR., J.R. O planejamento e controle da produção como condicionantes do sucesso competitivo da empresa construtora. Anais SINDUSCON-SP. São Paulo, 1999. Disponível em: <www.realestate.br>. Acesso em: 15 fev. 2005.

MACIEL, L.L.; MELHADO, S.B. Qualidade na construção civil: fundamentos. São Paulo: Escola Politécnica/USP, 1995. (TT/PCC/15)

MARCHESAN, P.R.C. Modelo integrado de gestão de custos e controle da produção para obras civis. 2001. Dissertação (Mestrado) - Escola de Engenharia, Universidade Federal do Rio Grande do Sul, Porto Alegre.

MARQUES JR., L.J. Uma contribuição para melhoria do planejamento de empreendimentos de construção em organizações públicas. 2000. Dissertação (Mestrado) Escola Politécnica, Universidade de São Paulo, São Paulo.

MARTINS, E.S. Um sistema para planejamento econômico-financeiro de empreendimentos imobiliários. 1998. Tese (Doutorado) - Escola Politécnica, Universidade de São Paulo, São Paulo.

MELHADO, S.B. Qualidade do projeto na construção de edifícios: aplicação ao caso de empresas de incorporação e construção. 1994. Tese (Doutorado) - Escola Politécnica, Universidade de São Paulo, São Paulo.

MELHADO, S.B. Gestão, cooperação e integração para um novo modelo voltado a qualidade do processo na construção de edifícios. 2001. Tese (Livre-Docência) - Escola Politécnica, Universidade de São Paulo, São Paulo. 
MESEGUER, A.G. Controle e garantia da qualidade na construção. São Paulo: Sinduscon-SP/Projeto/PW, 1991.

MINTZBERG, H. Criando organizações eficazes: estruturas em cinco configurações. 2.ed. São Paulo: Atlas, 2003.

MODER, J.J; PHILLIPS, C.R.; DAVIS, E.W. Project management with CPM, PERT, and precedence diagramming. 3.ed. Nova York: Van Nostrand Reinhold, 1983.

MURGEL, S.R. Planejamento e gerência de empreendimentos (conceitos e instrumentos): programação e controle de obras. 1981. Dissertação (Mestrado) - Escola Politécnica, Universidade de São Paulo, São Paulo.

NAKAGAWA, Y.; SHIMIZU, Y. Toyota Production System adopted by building construction in Japan. In: CONFERENCE OF THE INTERNATIONAL GROUP FOR LEAN CONSTRUCTION, 12., 2004, Copenhagen. Proceedings..., Copenhagen: IGLC, 2004.

NOVAIS, S.G. Aplicação de ferramentas para o aumento da transparência no processo de planejamento e controle de obra na construção civil. 2000. Dissertação (Mestrado) Escola de Engenharia Civil, Universidade Federal de Santa Catarina.

OHNO, T. Toyota Production System: beyond large-scale production. Cambridge, MA: Productivity Press, 1988.

OHNUMA, D.K. Modelo de processo para a gestão de subempreiteiros: estudo de casos em empresas construtoras de edifícios. 2003. Dissertação (Mestrado) - Escola Politécnica, Universidade de São Paulo, São Paulo.

PASTERNAK, A.J. Mercado exige agora um novo perfil de gestor de obras. Gazeta Mercantil, São Paulo, 4 de agosto do 2005.

PERROTTI, E. Estrutura organizacional e gestão do conhecimento. 2004. Dissertação (Mestrado) - Faculdade de Economia, Administração e Contabilidade, Universidade de São Paulo, São Paulo.

PICCHI, F.A. Sistema da qualidade: uso em empresas de construção. 1993. Tese (Doutorado) - Escola Politécnica, Universidade de São Paulo, São Paulo.

PICCHI, F.A. Oportunidades da aplicação do Lean Thinking na construção. Ambiente Construído, Porto Alegre, V3 N1, p. 7-23, 2003.

ROJAS, E.M.; MUKHERJEE, A. General-purpose situational simulation environment for construction education. Journal of construction engineering and management, ASCE, v.131, n.3, p.319-329, mar. 2005.

ROTHER, M.; HARRIS, R. Criando fluxo contínuo: um guia de ação para gerentes, engenheiros e associados da produção. Tradução de Lean Institute Brasil. São Paulo: Lean Institute Brasil, 2002. 
SALERNO, M.S. Projeto organizacional de produção integrada. 1998. Tese (LivreDocência) - Escola Politécnica, Universidade de São Paulo, São Paulo.

SANTIAGO JR., J.R.S. O desenvolvimento de uma metodologia para gestão do conhecimento em uma empresa de construção civil. 2002. Dissertação (Mestrado) - Escola Politécnica, Universidade de São Paulo, São Paulo.

SANTOS, A.L.P.; TURRA, F.; PANZETTER, A. Viabilidade da aplicação de planejamento e orçamento operacional. Foz de Iguaçu, PR. 2002. p. 1329-1338. In: IX Encontro Nacional de Tecnologia no Ambiente Construído. Artigo Técnico.

SANTOS, L.A. Diretrizes para elaboração de planos da qualidade em empreendimentos da construção civil. 2003. Dissertação (Mestrado) - Escola Politécnica, Universidade de São Paulo.

SANVIDO, V.; PAULSON, B. Site-Level construction information system. Journal of Construction Engineering and Management, v.118, n.4, p.701-715, 1992.

SEVERINO, A.J. Metodologia do trabalho científico. 22.ed. São Paulo: Cortez, 2002.

SILVA, S.A.R. Métodos de programação de empreendimentos: avaliação e critérios de seleção. 1993. Dissertação (Mestrado) - Escola Politécnica, Universidade de São Paulo.

SILVA, S.A.R. Programação por recursos: o desenvolvimento de um método de nivelamento e alocação com números nebulosos para o setor da construção civil. 1999. Tese (Doutorado) - Escola Politécnica, Universidade de São Paulo, São Paulo.

SOUZA, A.L.R. Preparação e coordenação da execução de obras: transposição da experiência francesa para a construção brasileira de edifícios. 2001. Tese (Doutorado) Escola Politécnica, Universidade de São Paulo, São Paulo.

SOUZA, R. Metodologia para desenvolvimento e implantação de sistemas de gestão da qualidade em empresas construtoras de pequeno e médio porte. 1997. Tese (Doutorado) Escola Politécnica, Universidade de São Paulo, São Paulo.

SOUZA, R. et al. Sistemas de gestão da qualidade para empresas construtoras. São Paulo: Pini, 1995.

SPEAR, S.; BOWEN, H.K. Decoding the DNA of the Toyota production system. Harvard Business Review. Boston, v.77, n.5, p.96-106, set./out. 1999.

TZORTZOPOULOS, P. Contribuições para o desenvolvimento de um modelo do processo de projeto de edificações em empresas construtoras incorporadoras de pequeno porte. 1999. Dissertação (Mestrado) - Universidade Federal do Rio Grande do Sul, Porto Alegre.

VARALLA, R. Planejamento e controle de obras. São Paulo: O Nome da Rosa, 2003.

VASCONCELLOS, E.; HEMSLEY, J.R. Estruturas das organizações: estruturas tradicionais, estruturas para inovação e estrutura matricial. 3.ed. São Paulo: Pioneira, 1997. 
VIVANCOS, A.G.; CARDOSO, F.F. Estruturas organizacionais de empresas construtoras de edifícios. São Paulo: Escola Politécnica/USP, 2001. (BT/PCC/306).

WOMACK, J.P. Criando o estado futuro. Lean Institute Brasil. 2003.

WOMACK, J.P.; JONES, D.T. A Mentalidade Enxuta nas empresas: elimine o desperdício e crie riqueza. 4. ed. Rio de Janeiro: Campus, 1998.

WOMACK, J.P.; JONES, D.T.; ROSS, D. A máquina que mudou o mundo. Rio de Janeiro: Campus, 1992.

YIN, R.K. Estudo de caso: planejamento e métodos. 3. ed. Porto Alegre: Bookman, 2005. 